PACIFIC NORTHWEST LABORATORY

ANNUAL REPORT FOR 1972 TO THE USAEC DIVISION OF BIOLOGICAL AND ENVI RONMENTAL RESEARCH VOLUME I LIFE SCIENCES PART 1 BIOLOGICAL SCIENCES

\title{
कัต Battelle
}

Pacific Northwest Laboratories

Richland, Washington 99352

\section{APRIL 1973}

Prepared for the U.S. Atomic Energy

Commission under Contract AT(45-1):1830 


\section{NOTICE}

This report was prepared as an account of work sponsored by the United States Government. Neither the United States nor the United States Atomic Energy Commission, nor any of their employees, makes any warranty. express or implied, or assumes any legal liability or responsibility for the accuracy, completeness or usefulness of any information, apparatus, product, or process disclosed, or represents that its use would not infringe privately-owned rights.

PACIFIC NORTHWEST LABORATORY

operated by

BATTELLE

for the

U.S. ATOMIC ENERGY COMMISSION

Under Contract AT(45-1)-1830

Printed in the United States of America

Available from

National Technical Information Service

U.S. Department of Commerce

5285 Port Royal Road

Springfield, Virginia 22151

Price: Printed Copy \$3.00; Microfiche $\$ 0.95$ 


\section{8} \\ by \\ The Staff of the Biology Department \\ Edited by \\ R. C. Thompson \\ PACIFIC NORTHWEST LABORATORY \\ ANNUAL REPORT FOR 1972 \\ TO THE \\ USAEC DIVISION OF BIOLOGICAL \\ AND ENVIRONMENTAL RESEARCH \\ VOLUME I LIFE SCIENCES \\ PART 1 BIOLOGICAL SCIENCES
}

Apri1 1973
BNWL-1750 PT 1

UC-48, Biology and Medicine
BATTELLE

PACIFIC NORTHWEST LABORATORIES

RICHLAND, WASHINGTON 99352 
This is the 22nd Annual Report of the Biology Department. Previous volumes are: HW-25021 (1951), HW-28636 (1952), HW-30437 (1953), HW-35917 (1954), HW-41500 (1955), HW-47500 (1956), HW-53500 (1957), HW-59500 (1958), $\mathrm{HW}-65500$ (1959), HW-69500 (1960), HW-72500 (1961), HW-76000 (1962), HW-80500 (1963), BNWL-122 (1964), BNWL-280 (1965), BNWL-480 (1966), BNWL-714 (1967), BNWL-1050 (1968), BNWL-1306 (1969), BNWL-1550 (1970), and BNWL-1650 (1971).

Part 2 of this volume, BNWL-1750 Part 2, covers work in the ecological sciences. Volume II of this report covers work in the physical sciences and is issued in three parts: Atmospheric Sciences BNWL-1751, Part 1; Radiological Sciences, BNWL-1751, Part 2; and Instrumentation, BNWL-1751, Part 3. 


\section{FOREWORD}

Reports of research performed during calendar year 1972 are grouped according to AEC budget categories and reflect a realignment of our program to attain better integration of multidisciplinary efforts.

Following the reports is a listing of the Department staff as organized at year's end. Major personnel changes during the year saw M. F. Gillis replacing W. J. Clarke as Manager of the Pathology Section, which was renamed Medical Sciences Section; and H. Drucker replacing W. R. Wiley as Manager of the Cellular and Molecular Biology Section, which was renamed Molecular Biology and Biophysics Section. Bil1 Clarke became Manager of Battelle Columbus' Biological and Medical Sciences Section of the Department of Biology, Environment and Chemistry. Bill wiley remains with us as a Staff Scientist and, on a part-time basis, is Coordinator of Battelle Institute life sciences programs in Richland, Columbus, Geneva, and Frankfurt laboratories.

A highlight of the year was the Twelfth Annual Hanford Symposium on Radionuclide Carcinogenesis held May 11-13, 1972, under the joint chairmanship of C. L. Sanders and R. H. Busch. The proceedings of this symposium will be published in the AEC Symposium Series.

A 1 ist of 1972 publications by personnel of the Biology Department appears at the end of this Annual Report. Requests for reprints will be honored as long as the supply lasts.

W. J. Bair, Manager Biology Department 


\section{TABLE OF CONTENTS}

FOREWORD

TOXICOLOGY OF INGESTED, INJECTED AND TOPICALLY APPLIED RADIONUCLIDES

Strontium-90 Studies in Miniature Swine - Mortality

and Tumor Incidence - H. A. Ragan, Beatrice J. McClanahan,

and Patricia L. Hackett

Strontium-90 Studies in Miniature Swine - Hematology

and Clinical Chemistry - Patricia L. Hackett and H. A. Ragan . . 3

Age-Related Effects of ${ }^{131}$ I in Rats - M. R. Sikov

and D. D. Mahlum.

Age-Related Effects of Plutonium in Rats - D. D. Mahlum

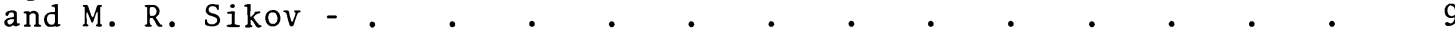

Plutonium in Miniature Swine - D. D. Mahlum . . . . . . . 11

Californium Studies - M. F. Sullivan, J. L. Beamer,

and A. C. Case $. \quad . \quad . \quad . \quad . \quad . \quad . \quad . \quad . \quad . \quad . \quad . \quad .11$

Einsteinium and Berkelium Toxicity and Metabolism in Rats -
D. D. Mahlum, F. P. Hungate, and M. R. Sikov . . . . . . . 12

Einsteinium Toxicity and Metabolism in Miniature Swine -

H. A. Ragan, Beatrice J. McClanahan, and Patricia L. Hackett • . 13

Skin Irradiation Studies - D. D. Mahlum . . . . . . . . $\quad 15$

Electron Microscopic Studies of Radiation Effects on Lipid

Absorption - J. C. Hampton . . . . . . . . . . . 16

Electron Microscopic Studies of Radiation Effects on

Capillary Permeability - J. C. Hampton . . . . . . $\quad .17$

Studies with a Protective Agent - J. C. Hampton . . . . . $\quad 19$

\section{TOXICOLOGY OF INHALED PLUTONIUM AND TRANSPLUTONIUM ELEMENTS}

Dose-Effect Studies with Inhaled Plutonium in Rats and Dogs -

J. E. Ballou, D. K. Craig, J. F. Park, H. A. Ragan, and

Carcinogenicity of Inhaled Plutonium-238 from Crushed

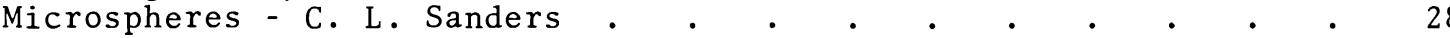

The Long-Term Biological Effects of Intratracheally

Instilled $25 \mathrm{EsCl}_{3}$ in Rats - J. C. Ballou and W. G. Morrow . . 32

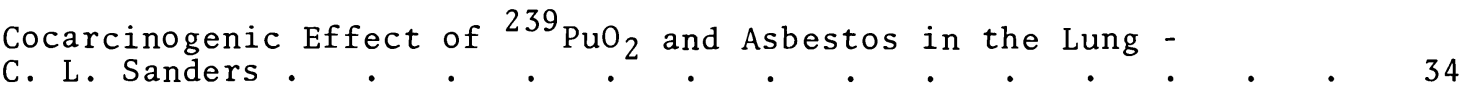

Biliary Excretion of Injected ${ }^{238} \mathrm{Pu}-\mathrm{C}$. Astley and

C. L. Sanders.

Detection of Cytotoxic Lymphocytes in Beagles with 
Direct Determination of the Percentage Total Deposition

of Aerosols Inhaled by Beagle Dogs - D. K. Craig,

$J$. R. Decker, and J. P. Herring

INHALATION HAZARDS TO URANIUM MINERS

Effects in Hamsters of Life-Span Inhalation Exposure to Simulated Uranium Mine Atmospheres - B. O. Stuart and R. H. Busch

Effects in Beagle Dogs of Life-Span Inhalation Exposure to Simulated Uranium Mine Atmospheres B. O. Stuart, R. H. Busch, H. A. Ragan, and

Comparative Effects in Hamsters, Rats, and Mice of

Exposure to Simulated Uranium Mine Atmospheres -

Characterization of Actual and Simulated Uranium Mine

Atmospheres - J. A. Cooper, P. O. Jackson, J. C. Langford, and $M . R$. Petersen

EVALUATION OF RADIONUCLIDES IN MAN

Evaluation of Postmortem Tissue Samples - I. C. Ne1son and V. W. Thomas, Jr. .

Diagnosis of Promethium Hazard in Man - I. C. Nelson,

D. B. Shipler, J. E. Ballou, and B. I. Griffin

REMOVAL OF RADIONUCLIDES

Pathologic Effects of Inhaled DTPA - J. E. Ballou, R. H. Busch, D. K. Craig, and V. H. Smith. .

Distribution and Retention of ${ }^{14}$ C-Labeled EDTA in Rats -

V. H. Smith

Long-Term Effects of DTPA Treatment of P1utonium

Effect of Fasting on Removal of Plutonium by DTPA -

C. L. Sanders.

DTPA-Enhanced Plutonium Excretion Via the Bile -

M. F. Sul1ivan

Chelatability of Plutonium in Blood - J. E. Ba1lou

Radiolytic Effects on Chelatability of Plutonium Oxide - V. H. Smith, J. F. Park, and D. K. Craig

Removal of Plutonium by Pulmonary Lavage -

K. E. McDonald

NUCLEAR-POWERED PROSTHESES AND OTHER HUMAN APPLICATIONS

Biological Effects of Intracorporeal Radioisotope Heat Sources - M. F. Gillis, J. R. Decker, W. K. Winegardner, M. T. Karagianes, and F. T. Cross 
Development and Evaluation of Blood Irradiators -

F. P. Hungate, B. I. Griffin, J. H. Jarrett, and

M. F. Gillis

MECHANISMS OF RADIATION EFFECTS

Induction of Exocellular Proteases - H. Drucker . . . . . 71

Control of Enzyme Induction at the Membrane Level -

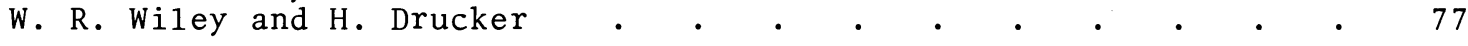

Studies on Nutrilite Transport - W. R. Wiley . . . . . . . 78

Studies on Tryptophan Metabolism - J. R. Turner . . . . . 81

Changes in the Specificity of Thermolysin as a Function

of Calcium Concentration - H. Drucker and M. Unger . . . $\quad 82$

Studies on the Role of Virus in Radionuclide-Induced

Malignancies - T. M. Frazier, R. N. Ushijima,

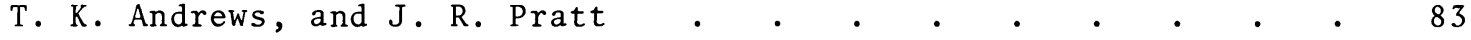

Studies on the Role of Radiation-Derived Free Radicals
in Biological Damage - D. R. Kalkwarf and W. D. Felix. . . . 85

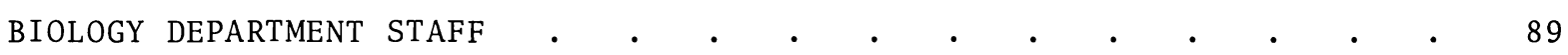

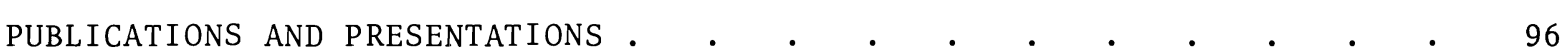


TOXICOLOGY OF INGESTED, INJECTED AND TOPICALLY APPLIED

RADIONUCLIDES

The studies reported in this section represent the efforts of a number of investigators, previously funded under several different project titles. We are combining these efforts under one title in the hope of developing a more highly coordinated approach to radionuclide toxicology. Answers are sought in three broad areas: (1) the biologic distribution and retention of radionuclides after entry by various routes; (2) the acute, subacute and long-term effects of these radionuclides; and (3) the factors apart from radionuclide exposure which may alter their biologic deposition and effect.

Included this year are reports on the continuing study of ${ }^{90} \mathrm{Sr}$ effects through three generations of miniature swine; age-related effects of ${ }^{131} \mathrm{I}$ and ${ }^{239} \mathrm{Pu}$ in rats; other studies of the metabolism and effects of Pu, Bk, Cf, and Es; and electron-microscopic studies of radiation effects on lipid absorption and capillary permeability, including some studies with a protective agent.

\section{PUBLICATIONS}

BAXTER, D. W. and M. F. SULLIVAN. Gastrointestinal Absorption and Retention of Plutonium Chelates. Health phys., vol. 22, p. 785.1972 .

CLARKE, W. J., R. H. BUSCH, P. L. HACKETT, E. B. HOWARD, M. E. FRAZIER, B. J. MCCLANAHAN, H. A. RAGAN, and G. S. VOGT. Strontium-90 Effects in Swine: A Summary to Date, p. 242. In: M. Goldman and $L$. K. Bustad

(Eds.), Biomedical Implications of Radiostrontium Exposure. (AEC Symposium Series 25) NTIS, Springfield, VA. 1972 .
CLARKE, W. J., P. L. HACKETT, M. E. FRAZIER, B. J. MCCLANAHAN, and H. A. RAGAN. Radiosensitivity of Swine to Chronic $90 \mathrm{Sr}$ Ingestion. Conference on Biological Effects of $90 \mathrm{Sr}$, University of California, Davis. (In press). 1972 .

HAMPTON, J. C. Acute Radiation Effects in Kidney. Radiat. Res., vol. 52, p. 316. $19 \overline{72 .}$

HAMPTON, J. C. and B. ROSARIO. The Fine Structure of Intestine and Liver in Irradiated Mice During Fat Absorption. Radiat. Res., vol. $52, p .152$. 1972 . 
HAMPTON, J. C. and B. ROSARIO. Radiation Effects on Chylomicron Synthesis in Mice. Radiat. Res., vol. 51, p. 441. (Abstract). 1972.

HAMPTON, J. C., B. ROSARIO, and R. R. ADEE. Exogenous Perioxidase Localization in Irradiated Arteries, p. 8 . In: 30 th Annual Meeting, Electron Microscopy Society of America. C. J. Arceneaux (Ed.), Claitor's Publishing Division, Baton Rouge. 1972.

HUNGATE, F. P., J. E. BALLOU, D. D. MAHLUM, M. KASHIMA, V. H. SMITH, C. L. SANDERS, D. W. BAXTER, M. R. SIKOV, and $R$. C. THOMPSON. Preliminary Data on $253 \mathrm{Es}$ and $249 \mathrm{Bk}$ Metabolism in Rats. Health Phys., vol. 22, p. 653. 1972.

KASHIMA, M., D. D. MAHLUM, and M. R. SIKOV. Metabolism and Effect of Monomeric and Polymeric Plutonium in the Immature Rat Liver. Health Phys., vol. $22, p .749 .1972$.

MAHLUM, D. D. Hepatic Tumor Development in Rats Exposed to $144 \mathrm{Ce}$ and Dimethylaminoazobenzene. In: Radionuclide Carcinogenesis, 12 th Annual Hanford Biology Symposium, May 11-13, 1972 .

MAHLUM, D. D. and M. R. SIKOV. Metabolism and Toxicity of $253 \mathrm{Es}$ Relative to Age. Radiat. Res., vol. 51, p. 502 (A bstract). 1972 .

Mahlum, D. D. and M. R. Sikov. Physico-chemical and Biological Interactions in Rare Earth Metabolism, p. 537. In: P. E. Field (Ed.), Proceedings of the 9 th Rare Earth Research Conference, vol. 2. (CONF711001) NTIS, Springfield, VA. 1972.

PALMER, R. F., J. M. THOMAS, C. R. WATSON, and $J$. L. BEAMER. Radiation Doses to $90 \mathrm{Sr}$-fed Swine, p. 114. In: M. Goldman and L. K. Bustad (Eds.), Biomedical Implications of Radiostrontium Exposure. (AEC Symposium Series 25) NTIS, Springfield, VA. 1972 .
RAGAN, H. A. Platelet Agglutination Induced by Ethylenediaminetetraacetic Acid in Blood Samples from a Miniature Pig. Amer. J. Vet. Res., vol. 33, p. 2601 . 1972.

RAGAN, H. A., P. L. HACKETT, B. J. MCCLANAHAN, and W. J. CLARKE. Pathologic Effects of Chronic $90 \mathrm{Sr}$ Ingestion in Miniature Swine. National Conference on Research Animals in Medicine. (In press). 1972.

SIKOV, M. R. and D. D. MAHLUM. AgeDependence of $239 \mathrm{Pu}$ Metabolism and Effect in the Rat, p. 261. In: B. J. Stover and W. S. S. Jee (Eds.), Radiobiology of Plutonium. J. W. Press, University of Utah, Salt Lake City. 1972 .

SIKOV, M. R. and D. D. MAHLUM. Distribution of $253 \mathrm{Es}$ in the Fetoplacental Unit of the Rat. Radiat. Res., vol. 51, p. 543. (Abstract). 1972 .

SIKOV, M. R. and D. D. MAHLUM. PZutonium in the Developing Animal. Health Phys., vol. 22, p. 707. 1972.

SIKOV, M. R., D. D. MAHLUM, and $W . J$. CLARKE. Effect of Age on the Carcinogenicity of ${ }^{131}$ I in the Rat. In: Radionuclide Carcinogenesis, $12 t \bar{h}$ Hanford Biology Symposium, May 11-13, 1972 .

SIKOV, M. R., D. D. MAHLUM, and E. B. HOWARD. Effect of Age on the Morphologic Response of the Rat Thyroid to Irradiation by Iodine-131. Radiat. Res., vol. 49, p. 233. 1972.

SULLIVAN, M. F., J. L. BEAMER, T. D. MAHONY, and B. W. WACHHOLZ. The Hanford Swine as a Model for Studies of Intracavitary Irradiation by Californium-252. Radiat. Res. vol. 51, p. 446. (Abstract). 1972.

WACHHOLZ, B. W., M. KASHIMA, and M. F. SULLIVAN. On the Mechanism of Protein Leakage by the Irradiated Intestine. Radiat. Res., vol. 51, p. 442. (Abstract). 1972 . 


\title{
STRONTIUM-90 STUDIES IN MINIATURE SWINE - MORTALITY
}

\section{AND TUMOR INCIDENCE}

\author{
Investigators: \\ H. A. Ragan, Beatrice J. McClanahan, \\ and Patricia L. Hackett \\ Technical Assistance: \\ Marizyn L. Greenwell, Eugenia T. Edmerson, \\ Darlene Hunter, Martha Perkins, and Glenda Vogt
}

\begin{abstract}
Studies to assess the Zong-term effects of daily ${ }^{90} \mathrm{Sr}$ feeding in miniature swine continue. An analysis of mortality using a life-table method showed that feeding 1 to $5 \mu \mathrm{Ci} / \mathrm{day}$ did not affect survival nor did $25 \mu \mathrm{Ci} / \mathrm{day}$ if given only during adult life. A number of measures, including neutrophil levels, uterine tumor incidence, myeloproliferation and leucocyte phagocytosis, have been found to be altered substantially, particularly at the higher levels of feeding.
\end{abstract}

In studies continuing for the past $14 \mathrm{yr}$, over 700 miniature swine, representing three generations, have been exposed to chronic ${ }^{90} \mathrm{Sr}$ feeding of $1,5,25,125,625$, or $3100 \mu \mathrm{Ci} /$ day. Sixty pigs survive from the original chronic toxicity study: twenty-seven controls, twenty-two

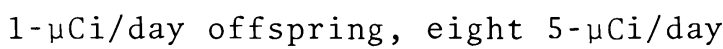

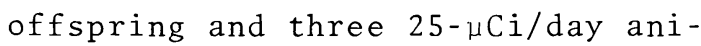
mals. Analysis of cumulative mortality data by a life-table method shows no difference between controls and parent and offspring generations fed 1 and $5 \mu \mathrm{Ci} /$ day (Figure 1 ). These groups have, therefore, been combined for purposes of statistical analysis. The survival of the parent generation that received $25 \mu \mathrm{Ci} /$ day was a1so not different from that of the above groups, but the offspring of this group showed a substantial increase in mortality after approximately 8 yr of age, due in part to

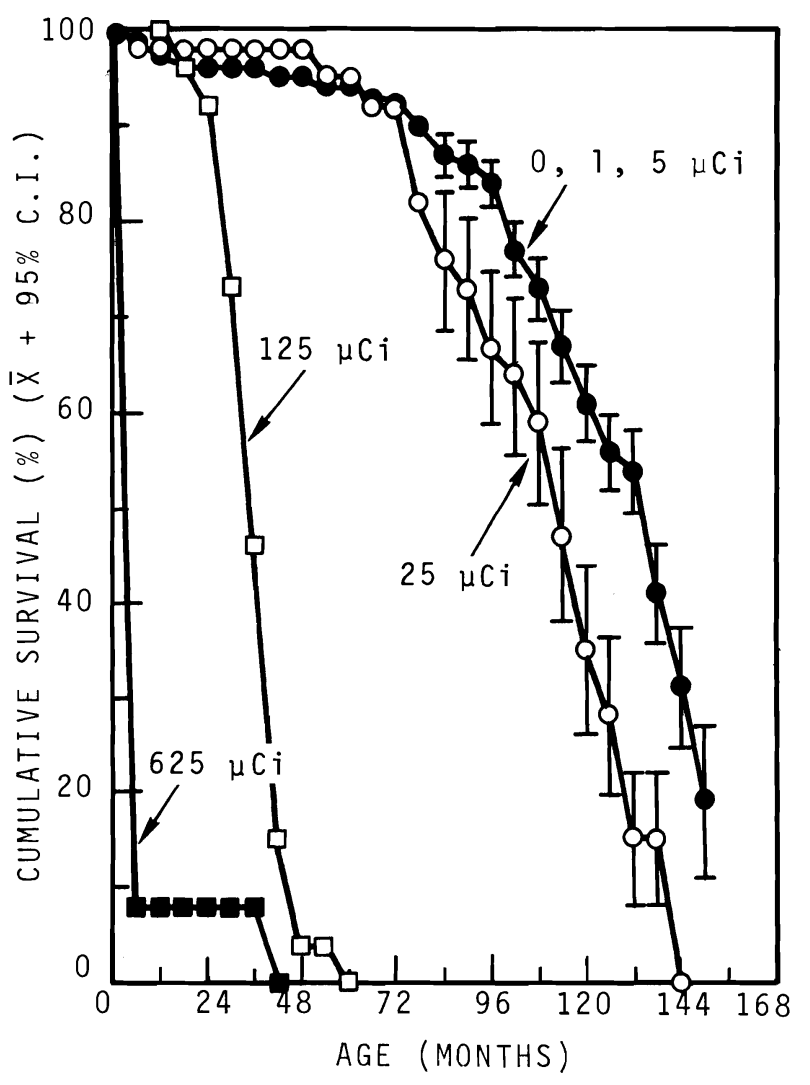

FIGURE 1. Miniature Swine Ingesting 90Sr Daily 
increased dental perialveolar degeneration and a higher incidence of soft tissue tumors (Table 1). In general, major indications for euthanasia in

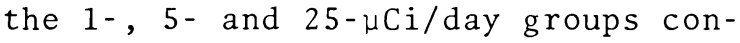
tinue to be uterine tumors (Figure 2), dental defects and arthritis, especially ankylosing spondylitis.

Twenty-four animals are being maintained as a pool for leukemogenesis studies. Fourteen of these have survived 38 to 48 months of daily ingestion of $125 \mu \mathrm{Ci}{ }^{90} \mathrm{Sr}$; ten were fed at the $250-\mu \mathrm{Ci} /$ day level to age 7 months and remain alive at 32 months of age.

Thirty-one animals survive in a study utilizing cross-fostering techniques and designed to define the importance of pre- and/or postnatal exposure to ${ }^{90} \mathrm{Sr}$ on the subsequent development of hematopoietic neoplasia. The mortality pattern in these animals, now 4 yr old, has been

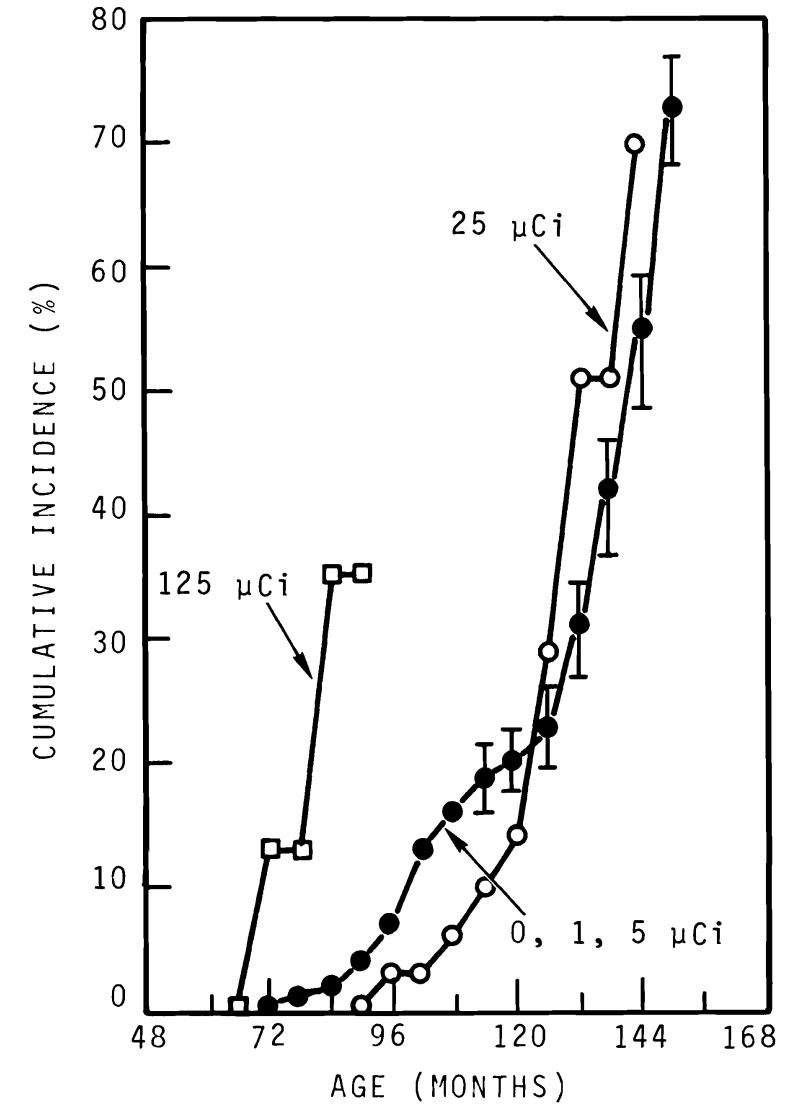

FIGURE 2. Uterine Tumors in Miniature Swine Ingesting $90 \mathrm{Sr}$ Daily (Combined Generations)

TABLE 1. Neoplasia and Myeloid Metaplasia in Miniature Swine Ingesting $90 \mathrm{Sr}$ Daily

\begin{tabular}{|c|c|c|c|c|c|c|c|c|c|c|c|c|c|}
\hline $\begin{array}{c}{ }_{90} \mathrm{Sr} \\
(\mu \mathrm{C} / \text { day })\end{array}$ & Generation & 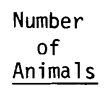 & $\begin{array}{c}\text { Annual } \\
\text { Skeletal Dose } \\
\left(\text { rad } \times 10^{3}\right) \\
\end{array}$ & Bone & $\begin{array}{l}\text { Stem } \\
\text { Cell } \\
\end{array}$ & $\begin{array}{c}\begin{array}{c}\text { Myeloid } \\
\text { Neo- } \\
\text { plasia } \\
\end{array} \\
\end{array}$ & $\begin{array}{l}\text { Lympho- } \\
\text { reticular } \\
\end{array}$ & Uterine & Ovarian & Hepatic & Other & $\begin{array}{c}\text { Total } \\
\text { Neoplasms } \\
\end{array}$ & $\begin{array}{r}\text { Myeloi } \\
\text { Meta- } \\
\text { plasia }\end{array}$ \\
\hline 0 & -- & 183 & -- & 0 & 0 & 2 & 1 & 17 & $1^{d}$ & 2 & 3 & 26 & 0 \\
\hline 1 & $\begin{array}{l}p^{a} \\
0^{b}\end{array}$ & $\begin{array}{l}24 \\
64\end{array}$ & $\begin{array}{l}0.02 \\
0.03\end{array}$ & $\begin{array}{l}0 \\
0\end{array}$ & $\begin{array}{l}0 \\
0\end{array}$ & $\begin{array}{l}0 \\
0\end{array}$ & $\begin{array}{l}1 \\
4\end{array}$ & $11^{6^{d}}$ & $\begin{array}{l}0 \\
0\end{array}$ & $\begin{array}{l}1 \\
1\end{array}$ & $\begin{array}{l}0 \\
3\end{array}$ & $\begin{array}{r}8 \\
19\end{array}$ & $\begin{array}{l}1 \\
1\end{array}$ \\
\hline 5 & $\begin{array}{l}P \\
0\end{array}$ & $\begin{array}{l}10 \\
36\end{array}$ & $\begin{array}{l}0.12 \\
0.13\end{array}$ & $\begin{array}{l}0 \\
0\end{array}$ & $\begin{array}{l}0 \\
0\end{array}$ & $\begin{array}{l}0 \\
0\end{array}$ & $\begin{array}{l}0 \\
1\end{array}$ & $\begin{array}{l}2 \\
8\end{array}$ & $\begin{array}{l}0 \\
0\end{array}$ & $\begin{array}{l}0 \\
1\end{array}$ & $\begin{array}{l}0 \\
0\end{array}$ & $\begin{array}{r}2 \\
10\end{array}$ & $\begin{array}{l}0 \\
0\end{array}$ \\
\hline 25 & $\begin{array}{l}P \\
0\end{array}$ & $\begin{array}{l}19 \\
41\end{array}$ & $\begin{array}{l}0.6 \\
0.7\end{array}$ & $\begin{array}{l}0 \\
0\end{array}$ & $\begin{array}{l}0 \\
0\end{array}$ & $\begin{array}{l}2 \\
2\end{array}$ & $\begin{array}{l}0 \\
2\end{array}$ & $\begin{array}{l}7 e \\
5\end{array}$ & $\begin{array}{l}1 \\
3\end{array}$ & $\begin{array}{l}2 \\
4\end{array}$ & $\begin{array}{l}3 \\
4\end{array}$ & $\begin{array}{l}15 \\
20\end{array}$ & $\begin{array}{l}0 \\
5\end{array}$ \\
\hline 125 & $\begin{array}{l}P \\
0\end{array}$ & $\begin{array}{l}16 \\
27\end{array}$ & $\begin{array}{l}3 \\
4\end{array}$ & $\begin{array}{l}0 \\
9\end{array}$ & $\begin{array}{l}0 \\
3\end{array}$ & $\begin{array}{r}3 \\
14\end{array}$ & $\begin{array}{l}1 \\
7\end{array}$ & $\begin{array}{l}2 \\
0\end{array}$ & $\begin{array}{l}0 \\
0\end{array}$ & $\begin{array}{l}0 \\
0\end{array}$ & $\begin{array}{l}0 \\
0\end{array}$ & $\begin{array}{r}6 \\
33\end{array}$ & $\begin{array}{l}3 \\
2\end{array}$ \\
\hline 625 & $\begin{array}{l}P \\
{ }^{C} \mathrm{C}\end{array}$ & $\begin{array}{l}14 \\
13\end{array}$ & $\begin{array}{l}15 \\
20\end{array}$ & $\begin{array}{l}0 \\
2\end{array}$ & $\begin{array}{l}0 \\
0\end{array}$ & $\begin{array}{l}0 \\
1\end{array}$ & $\begin{array}{l}0 \\
1\end{array}$ & $\begin{array}{l}0 \\
0\end{array}$ & $\begin{array}{l}0 \\
0\end{array}$ & $\begin{array}{l}0 \\
0\end{array}$ & $\begin{array}{l}0 \\
0\end{array}$ & $\begin{array}{l}0 \\
5\end{array}$ & $\begin{array}{r}3 \\
15\end{array}$ \\
\hline 3100 & $P$ & 5 & 72 & 0 & 0 & 0 & 0 & 0 & 0 & 0 & 0 & 0 & 2 \\
\hline \multicolumn{14}{|c|}{$\begin{array}{l}\text { aparent } \\
\mathrm{b}_{\text {Offspring }} \\
\mathrm{c}_{\text {Removed from }} 90_{\mathrm{Sr}} \text { feeding a } \\
\mathrm{d}_{1} \text { metastatic adenocarcinoma } \\
\mathrm{e}_{1} \text { leiomyosarcoma }\end{array}$} \\
\hline
\end{tabular}


extremely interesting. Of those exposed via the milk only, 10 of $10 \mathrm{re-}$ main alive. Of those exposed in utero and via the milk, 8 of 8 remain alive. Of those exposed in utero only, 7 of 10 are alive; 2 of the 3 deaths were from nonradiationassociated causes, one from acute necrotizing pancreatitis and the other from traumatic posterior paralysis; the third animal had extensive myeloid metaplasia. It is not known whether the myeloid metaplasia is radiation-induced since the fetal dose to these animals was only about 50 rads. However, no lesions suggesting myeloid metaplasia have been observed in more than 200 control ani- mals. Of the animals exposed throughout life - in utero, via the milk, and in the feed - 4 of 9 remain alive; 2 died of hematopoietic depression and 1 of myeloproliferative disease. Surprisingly, only 2 of 10 animals remain alive in the group exposed via milk and subsequently by feeding. Six died with severe hematopoietic depression and 2 with myeloproliferation. The survivors of this experiment are being carefully studied for changes in their blood chemistry. An elevated alkaline phosphatase, arising mainly as the intestinal isoenzyme, appears to occur in animals that received ${ }^{90} \mathrm{Sr}$ only during the nursing period.

\title{
STRONTIUM-90 STUDIES IN MINIATURE SWINE - HEMATOLOGY
}

\section{AND CLINICAL CHEMISTRY}

Investigators:

Patricia L. Hackett and H. A. Ragan

Technical Assistance:

Eugenia T. Edmerson, Darlene Hunter, Martha Perkins, and Glenda Vogt

\begin{abstract}
Blood from miniature swine ingesting ${ }^{90} \mathrm{Sr}$ was analyzed for a number of components in an attempt to characterize the clinical state. Several measures, including levels of thrombocytes, neutrophils and glutamic oxaloacetic transaminase, as well as the phagocytic capacity of leukocytes, were altered as a result of the $90 \mathrm{Sr}$ regimen.
\end{abstract}

A number of hematologic parameters have been measured in our ${ }^{90} \mathrm{Sr}$ swine. The major changes found in animals receiving $125 \mu \mathrm{Ci} /$ day and above have been thrombocytopenia, panleukopenia and a terminal, rapidly progressive anemia. At 1,5 , and $25 \mu \mathrm{Ci} /$ day, the major change has been a chronic neutropenia (Figure 1). 


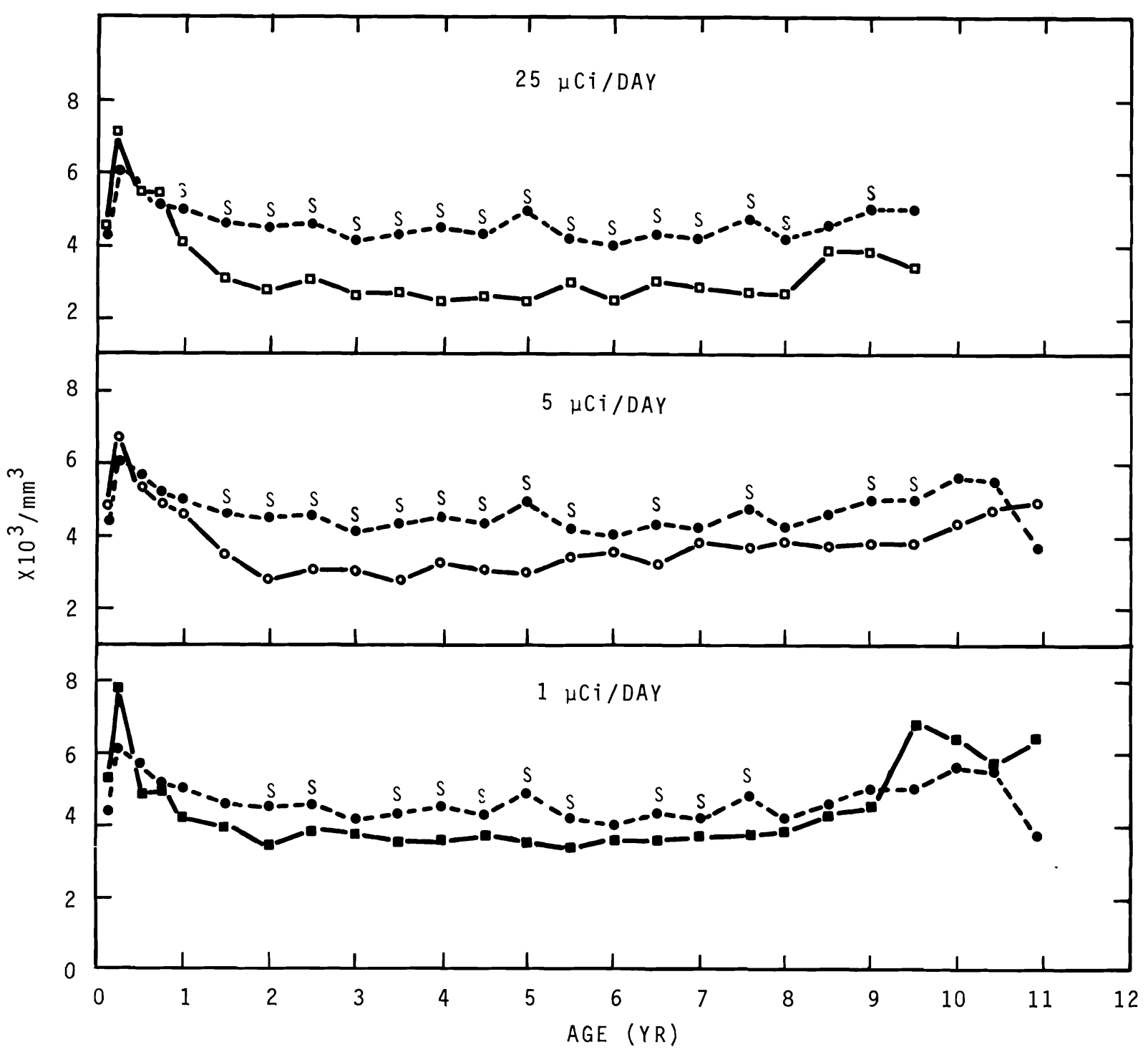

FIGURE 1. Segmented Neutrophils in ${ }^{90} \mathrm{Sr}$ and Control Miniature Swine Offspring (Upper curve in the control; "S" indicates a significant difference; $P<0.05$. )

Serum samples have been analyzed for a number of constituents in attempts to associate changes in the clinical chemistry picture with diagnosis of the clinical state (Table 1). Renal function as judged by levels of blood urea nitrogen (BUN) and by creatinine values is only slightly impaired even by terminal conditions. Serum glutamic oxalacetic transaminase (SGOT) levels are increased in nearly al1 neoplastic conditions and in animals exhibiting central nervous system derangement. Serum glutamic pyruvic transaminase (SGPT) is elevated in animals exhibiting central nervous system signs and depressed in animals showing long-term 


\begin{tabular}{|c|c|c|c|c|c|c|c|c|c|c|c|c|c|c|}
\hline \multirow[b]{2}{*}{$\begin{array}{l}\text { Tentative } \\
\text { Diagnosis }\end{array}$} & \multirow[b]{2}{*}{$\begin{array}{r}{ }^{90} \text { Sr } \\
\text { Leve } \\
(\mu C i) \\
\end{array}$} & \multicolumn{3}{|c|}{$\frac{\text { TABLE } 1}{\text { in the }}$ Serum } & $\begin{array}{l}\text { Profile } \\
y\end{array}$ & es of & Termina & \multicolumn{2}{|c|}{1 Samples } & from & Swine & \multirow{3}{*}{$\begin{array}{c}\text { SGOT } \\
\text { (Units) } \\
\end{array}$} & \multirow[b]{2}{*}{$\begin{array}{c}\text { SGPT } \\
\text { (Units) }\end{array}$} & \multirow[b]{2}{*}{$\begin{array}{c}\text { LDH } \\
\text { (Units) } \\
\end{array}$} \\
\hline & & $\begin{array}{l}\text { Animal } \\
\text { (No.) }\end{array}$ & $\begin{array}{c}\text { Age } \\
\text { (Month) }\end{array}$ & $\begin{array}{c}\text { BUN } \\
\text { (mg/100 ml) } \\
\end{array}$ & $\begin{array}{r}\text { Creatinine } \\
(\mathrm{mg} / 100 \mathrm{ml})\end{array}$ & $\begin{array}{l}\text { Protein } \\
(\mathrm{g} / 100 \mathrm{ml})\end{array}$ & $\begin{array}{c}\text { Albumin } \\
(\mathrm{g} / 100 \mathrm{ml})\end{array}$ & $\frac{\text { Globul }}{\text { Alpha }}$ & $\frac{\text { in }(\mathrm{g} / 100}{\text { Beta }}$ & $\frac{\mathrm{ml} \text { ) }}{\text { Gamma }}$ & $\begin{array}{l}\text { Alkaline } \\
\text { Phosphatase } \\
\text { (Units) } \\
\end{array}$ & & & \\
\hline \multicolumn{14}{|c|}{ 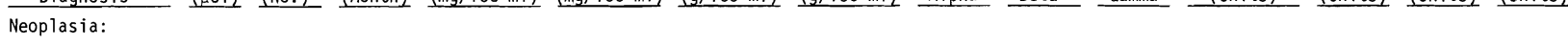 } & \\
\hline Leukemia & $\begin{array}{r}0 \\
250\end{array}$ & $\begin{array}{l}1269 \\
4133\end{array}$ & $\begin{array}{r}120 \\
35\end{array}$ & $\begin{array}{l}59 \\
21\end{array}$ & $\begin{array}{l}3.2 \\
1.3\end{array}$ & $\begin{array}{l}9.0 \\
8.2\end{array}$ & $\begin{array}{l}2.2 \\
2.9\end{array}$ & $\begin{array}{l}1.8 \\
1.5\end{array}$ & $\begin{array}{l}2.0 \\
1.4\end{array}$ & $\begin{array}{l}3.0 \\
2.4\end{array}$ & $\begin{array}{l}6.9 \\
0.7\end{array}$ & $\begin{array}{l}74 \\
68\end{array}$ & $\begin{array}{l}7 \\
--\end{array}$ & $\begin{array}{l}1162 \\
1448\end{array}$ \\
\hline Lymphosarcoma & 25 & 695 & 140 & 10 & 1.3 & 7.8 & 1.7 & 1.8 & 1.7 & 2.6 & 1.6 & 38 & 16 & 1400 \\
\hline $\begin{array}{l}\text { Ovarian } \\
\text { Adenocarcinoma }\end{array}$ & 25 & 697 & 140 & 65 & 1.6 & 6.0 & 0.3 & 2.8 & 1.2 & 1.7 & 10.8 & 220 & 31 & 3400 \\
\hline Diffuse & 1 & 1016 & 123 & 34 & 1.8 & 9.5 & 3.1 & 2.6 & 1.8 & 2.0 & 11.8 & 545 & 60 & 13900 \\
\hline Uterine Tumor & $\begin{array}{l}0 \\
0 \\
0 \\
1 \\
1 \\
1 \\
5\end{array}$ & $\begin{array}{r}308 \\
1278 \\
1288 \\
494 \\
585 \\
627 \\
456\end{array}$ & $\begin{array}{l}149 \\
115 \\
120 \\
147 \\
142 \\
140 \\
152\end{array}$ & $\begin{array}{l}33 \\
15 \\
17 \\
22 \\
18 \\
17 \\
27\end{array}$ & $\begin{array}{l}1.7 \\
1.1 \\
2.2 \\
1.6 \\
1.8 \\
1.8 \\
1.7\end{array}$ & $\begin{array}{l}8.5 \\
7.8 \\
8.6 \\
8.2 \\
8.7 \\
6.6 \\
7.6\end{array}$ & $\begin{array}{l}2.4 \\
1.6 \\
3.3 \\
3.3 \\
3.7 \\
2.4 \\
3.2\end{array}$ & $\begin{array}{l}2.7 \\
1.9 \\
1.3 \\
1.6 \\
1.6 \\
1.4 \\
1.2\end{array}$ & $\begin{array}{l}1.7 \\
1.9 \\
1.5 \\
1.7 \\
2.0 \\
1.3 \\
1.6\end{array}$ & $\begin{array}{l}1.7 \\
2.4 \\
2.5 \\
1.6 \\
1.4 \\
1.5 \\
1.6\end{array}$ & $\begin{array}{l}1.5 \\
0.6 \\
1.4 \\
2.7 \\
1.7 \\
0.6 \\
0.8\end{array}$ & $\begin{array}{r}144 \\
25 \\
15 \\
80 \\
49 \\
38 \\
21\end{array}$ & $\begin{array}{r}41 \\
10 \\
14 \\
36 \\
18 \\
9 \\
21\end{array}$ & $\begin{array}{r}780 \\
1213 \\
1150 \\
1000 \\
650 \\
763 \\
650\end{array}$ \\
\hline Aplasia & $\begin{array}{l}125 \\
125\end{array}$ & $\begin{array}{l}4007 \\
3491\end{array}$ & $\begin{array}{l}36 \\
42\end{array}$ & $\begin{array}{l}16 \\
20\end{array}$ & $\begin{array}{l}1.3 \\
1.2\end{array}$ & $\begin{array}{l}7.9 \\
9.2\end{array}$ & $\begin{array}{l}4.0 \\
2.7\end{array}$ & $\begin{array}{l}1.4 \\
2.1\end{array}$ & $\begin{array}{l}1.3 \\
2.1\end{array}$ & $\begin{array}{l}1.2 \\
2.3\end{array}$ & $\begin{array}{l}0.7 \\
2.1\end{array}$ & $\begin{array}{l}21 \\
50\end{array}$ & $\begin{array}{r}8 \\
20\end{array}$ & $\begin{array}{r}1046 \\
750\end{array}$ \\
\hline C.N.S. Signs & 0 & 4041 & 36 & 20 & 1.9 & 8.9 & 3.3 & 1.3 & 2.3 & 2.0 & 2.7 & 1580 & 111 & -- \\
\hline $\begin{array}{l}\text { Ankylosing } \\
\text { Spondylitis }\end{array}$ & 5 & 340 & 157 & 50 & 3.1 & 7.1 & 2.6 & 1.1 & 1.7 & 1.7 & 3.0 & 780 & 250 & 1828 \\
\hline $\begin{array}{l}\text { Control Values } \\
\text { (Range) }\end{array}$ & & & & $13-28$ & $0.9-2.3$ & $6.6-9.0$ & $2.5-3.8$ & $0.8-1.6$ & $1.2-1.9$ & $1.4-2.4$ & $1.2-5.7$ & $18-48$ & $29-50$ & $460-880$ \\
\hline
\end{tabular}

anorexia. Serum albumin levels are also depressed in long-term anorectic animals. Total lactic dehydrogenase $(\mathrm{LDH})$ values are most frequently increased in samples obtained at necropsy and have not shown particular correlation with the disease process, although the value obtained for Pig No. 1016, which had diffuse neoplasia, is the highest encountered in these miniature swine. Studies on specific LDH isoenzymes are now in progress to determine if changes in patterns of isoenzymes may show correlation with pathologic diagnosis.

Miniature swine presently receiving $125 \mu \mathrm{Ci}{ }^{90} \mathrm{Sr} /$ day and kept as a "leukemic pool" show a lower incidence or longer induction period for leukemia than was the case in the

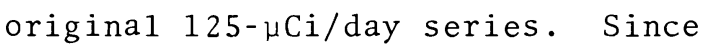
about half of the animals in the "leukemic pool" were derived from
Pitman-Moore dams and about half from Hanford Miniature dams, serum constituents were compared between these two groups and some differences became apparent (Figure 2). Serum a1bumin tended to be lower in the Hanford Miniature but globulins (especially gamma globulin) were higher. Cholesterol levels were lower in the Hanford Miniature, at least for the first 21 months of 1ife. This cholesterol level probably correlates with thyroid activity and growth rate. Although LDH activity was not significantly different between the two groups, the Hanford Miniature usually had the lower value. Serum alkaline phosphatase activity was consistently higher in Pitman-Moore pigs up to 30 months of age.

There has been some indication that red cel1 lifespan might be 


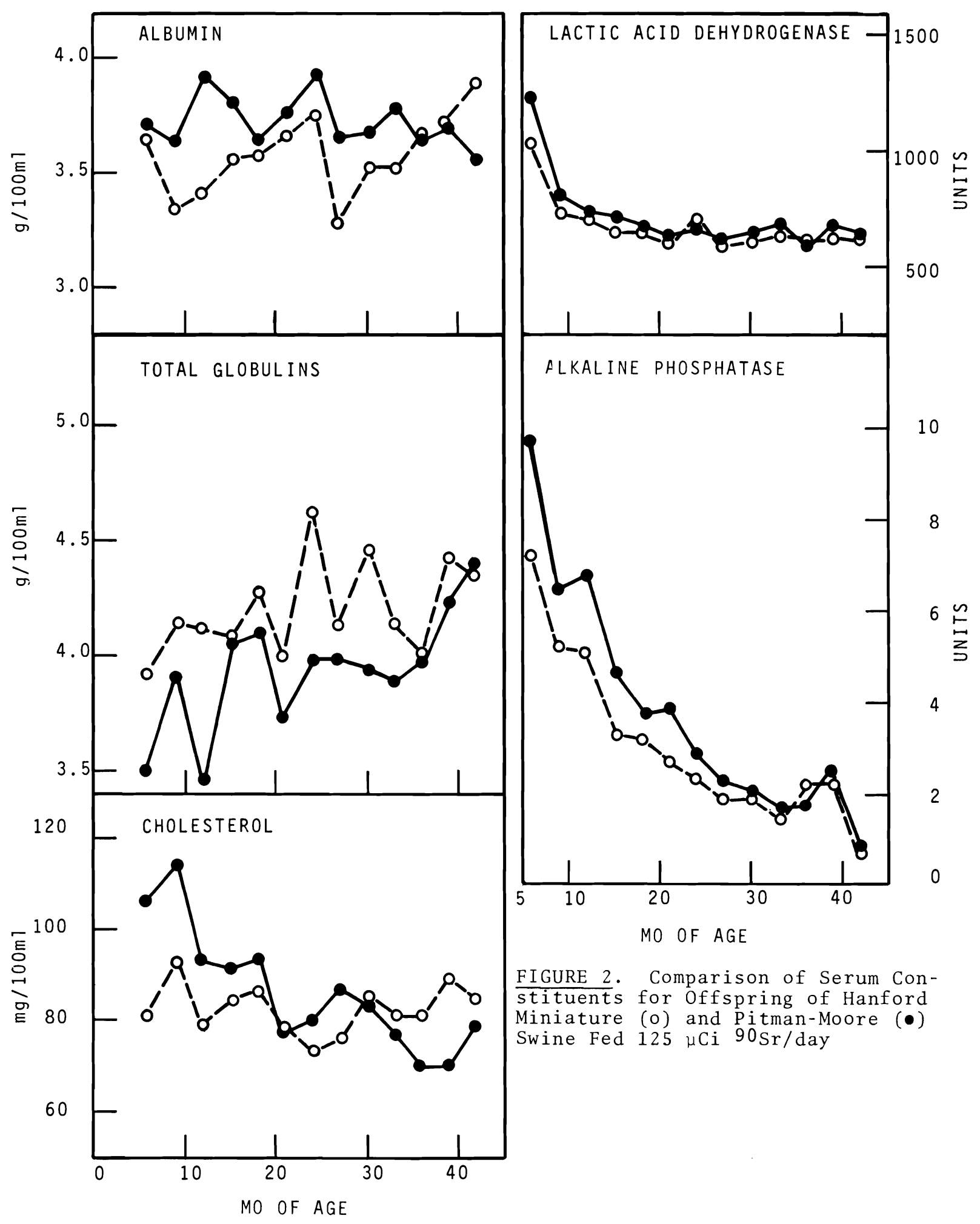


changed in animals ingesting ${ }^{90} \mathrm{Sr}$. This change could be due to the synthesis of an abnormal hemoglobin molecule in the normoblast exposed to chronic irradiation. To study this possibility, hemolysates of peripheral red cells were subjected to electrophoresis on cellulose acetate strips. No difference in mobility could be detected between hemoglobin from ${ }^{90} \mathrm{Sr}$-exposed and control pigs. A more sensitive procedure of peptide mapping, utilizing chromatographic and electrophoretic techniques, is presently being applied to this problem.
In another effort to assess radiation damage, we have measured the ability of peripheral leukocytes to ingest foreign particulate matter. Leukocytes from animals exposed to either 125 or $250 \mu \mathrm{Ci}{ }^{90} \mathrm{Sr}$ showed a reduced capacity to ingest these particles of yeast cell walls tagged with nitro blue tetrazolium. This reduced capacity is reflected by a decrease in both the percentage of cells containing particles and the average number of particles per ce11.

\title{
AGE-RELATED EFFECTS OF ${ }^{131}$ I IN RATS
}

Investigators:

M. R. Sikov and D. D. Mahlum

Technical Assistance:

Joan O. Hess and Jean D. Stearns

\begin{abstract}
Recently completed studies on the long-term effects of ${ }^{131}$ I have shown age-related differences in the susceptibility to induction of thyroid and pituitary tumors. Manipulation of pregnant rats appears to increase the incidence of thyroid tumors and induced a variety of adrenal alterations in offspring.
\end{abstract}

An experiment on the carcinogenicity of ${ }^{131} \mathrm{I}$ in rats, relative to age at exposure, is completed except for final analysis of the data. This final analysis will probably result in only minor changes in tumor incidence figures. Data on other pathology, survival time, etc., remain to be analyzed. Radiation dose estimates were made for each age-dose group based on radioanalysis of animals sacrificed during and following exposure. Uptake of a tracer dose of ${ }^{125}$ I was determined as a measure of thyroid function $24 \mathrm{hr}$ prior to sacrifice of surviving animals at 30 months of age.

No thyroid tumors have been found in the adult control group and only 
a low incidence $(2 / 21)$ in the weanling controls (Table 1). There was an appreciably greater incidence among the controls for the newborn and prenata 1 exposure groups, 5/28 and $11 / 56$, respectively. It would appear that these differences among control groups are real and perhaps are related to the trauma associated with multiple gavage of the dams of these animals.

In a11 age groups, a thyroid radiation dose in the range of hundreds of rads resulted in an appreciably increased incidence of thyroid tumors (8/45 for adults receiving 175 rads, $26 / 67$ for wean 1 ings receiving 700 rads, $22 / 69$ for newborns receiving 250 rads and $20 / 74$ for the prenata $11 y$ exposed receiving 425 rads). Groups exposed to higher thyroid doses (2000 rads or greater) had a lower than peak incidence of thyroid tumors, except for the group in which exposure started at 17 days of gestation, where an estimated dose of 3400 rads at the highest 1 evel and 40 rads at the lowest level both produced a high incidence of thyroid tumors.

The incidence of pituitary tumors was approximately $10 \%$ in the controls for the three older exposure groups; the control incidence for the pre-

\begin{tabular}{|c|c|c|c|}
\hline \multicolumn{4}{|c|}{$\begin{array}{l}\text { TABLE 1. Effect of Age on the In- } \\
\text { cidence of Thyroid and Pituitary } \\
\text { Tumors Following Exposure to Mul- } \\
\text { tiple Doses of } 131 \mathrm{I}\end{array}$} \\
\hline $\begin{array}{c}\text { Age at } \\
\text { Exposure } \\
\end{array}$ & $\begin{array}{l}\text { Total Dose } \\
\text { to Thyroid } \\
\text { (rads) } \\
\end{array}$ & $\begin{array}{l}\text { Thyroid } \\
\text { Tumors } \\
\end{array}$ & $\begin{array}{c}\text { Pituitary } \\
\text { Tumors }\end{array}$ \\
\hline Adult & $\begin{array}{r}0 \\
175 \\
1,960 \\
16,600\end{array}$ & $\begin{array}{l}0 / 15 \\
8 / 45 \\
4 / 37 \\
0 / 46\end{array}$ & $\begin{array}{l}1 / 12 \\
3 / 20 \\
2 / 35 \\
6 / 43\end{array}$ \\
\hline Weanling & $\begin{array}{r}0 \\
50 \\
700 \\
5,475\end{array}$ & $\begin{array}{r}2 / 21 \\
5 / 57 \\
26 / 67 \\
12 / 71\end{array}$ & $\begin{array}{l}2 / 21 \\
4 / 49 \\
9 / 55 \\
8 / 57\end{array}$ \\
\hline Newborn & $\begin{array}{r}0 \\
20 \\
280 \\
2,200\end{array}$ & $\begin{array}{r}5 / 28 \\
10 / 77 \\
22 / 69 \\
7 / 78\end{array}$ & $\begin{array}{l}3 / 27 \\
9 / 64 \\
8 / 55 \\
8 / 51\end{array}$ \\
\hline Prenata 1 & $\begin{array}{r}0 \\
40 \\
425 \\
3,390\end{array}$ & $\begin{array}{l}11 / 56 \\
28 / 73 \\
20 / 74 \\
35 / 81\end{array}$ & $\begin{array}{r}9 / 51 \\
9 / 60 \\
20 / 75 \\
23 / 77\end{array}$ \\
\hline
\end{tabular}

natally exposed animals was somewhat higher (18\%) and was further elevated at the two higher ${ }^{131}$ I levels. The incidence of mammary tumors and of adrenal lesions appeared to be elevated in the newborn and prenatal controls. The incidence of mammary tumors was also increased by postnatal but not by prenatal exposure to ${ }^{131} \mathrm{I}$. 


\title{
AGE-RELATED EFFECTS OF PLUTONIUM IN RATS
}

\section{Investigators:}

D. D. Mahlum and M. R. Sikov

Technical Assistance:

Joan 0 . Hess and Jean D. Stearns

\begin{abstract}
An experiment, still in progress, compares the long-term effects of monomeric $239 \mathrm{Pu}$ administered to rats at various ages. Bone tumor incidence is initially higher in males than in females and in animals injected as adults.
\end{abstract}

Exposures were completed in an experiment studying age-related effects of monomeric ${ }^{239} \mathrm{Pu}$ in the rat. Animals exposed as adults and weanlings received intravenous doses of 0.3 , 1.0 and $3.0 \mu \mathrm{Ci} / \mathrm{kg}$; higher doses were administered to the newborn and prenatal groups (Table 1). Each agedose group consists of approximately 25 males and 25 females on long-term study, with additional animals sacrificed at various times after exposure for radioanalysis and calculation of radiation doses. Samples of bone are taken for radioanalysis at time of death to define the long-term dose to the bone. The radiation doses in the adult- and weanling-exposed animals were similar to those predicted in designing the experiment; doses received at 1 ater times by the animals exposed prenatally or as newborns were somewhat greater than anticipated. The experiment is still in progress, and the discussion which

TABLE 1. Experimental Protocol for Study of Long-Term Effects of $239 \mathrm{Pu}$ in Rats. Estimated radiation doses (rads) to the femurs are shown for the first 30 days postexposure.

\begin{tabular}{|c|c|c|c|c|c|c|c|c|}
\hline Age at & & $\mathrm{Ad}$ & niste & ed Dos & $(\mu \mathrm{Ci} / \mathrm{k}$ & Body & $g h t)$ & \\
\hline Injection & 0.3 & 1.0 & 3.0 & $\underline{6.0}$ & 10.0 & 20.0 & 30.0 & 60.0 \\
\hline Adu1t & 15 & 50 & 145 & & & & & \\
\hline Wean1ing & 15 & 55 & 165 & & & & & \\
\hline Newborn & & 5 & 20 & & 60 & & 180 & \\
\hline Prenata $1^{\mathrm{a}}$ & & & & 5 & & 10 & & 30 \\
\hline $\begin{array}{l}{ }^{a} \text { Pregnant } \\
\text { Radiation } \\
\text { via milk. } \\
\text { were expo } \\
\text { fostering }\end{array}$ & $\begin{array}{l}\text { were } \\
\text { e is } \\
\text { the } \\
\text { in ut } \\
\text { hnnigu }\end{array}$ & $\begin{array}{l}\text { inject } \\
\text { timat } \\
\mu \mathrm{Ci} \\
\text { co on } \\
\text {. }\end{array}$ & $\begin{array}{l}\text { at } \\
\text { fro } \\
\text { dos } \\
\text { or v }\end{array}$ & $\begin{array}{l}\text { days } \\
\text { exposi } \\
\text { leve1 } \\
\text { the }\end{array}$ & $\begin{array}{l}\text { ges } \\
\text { in } \\
\text { iddit } \\
\text { k on }\end{array}$ & $\begin{array}{l}\text { ion. } \\
1 \text { and } \\
1 \text { gro } \\
y \text { cro }\end{array}$ & & \\
\hline
\end{tabular}


follows is subject to revision when complete data are available.

Starting at about a year postexposure, substantial mortality occurred in the adult and weanling groups exposed to the 1.0 and $3.0 \mu \mathrm{Ci} / \mathrm{kg}$ doses. A substantial number of deaths were seen somewhat earlier in the newborn group exposed to $30 \mu \mathrm{Ci} / \mathrm{kg}$. In the weanling and adult groups, the pattern of early mortality shows males dying at a substantially greater rate than females. This sex dependency was also apparent in the $30 \mu \mathrm{Ci} / \mathrm{kg}$ newborn group but is not apparent at lower doses or in animals exposed prenatally.

A sex difference is also seen in the incidence of tumors. At the intermediate dose level in the adult group, six bone tumors have appeared in males and none in the females; at the highest dose level there have been 13 tumors in males and only 3 in females. The incidence of bone tumors in other groups is too low to make a comparison at this time. A number of nonneoplastic bone changes are seen predominantly in animals exposed as weanlings.

Occasional cases of leukemia, predominantly chloroleukemia, have been observed in several of the Pu-treated experimental groups, with only a single case appearing in controls. The highest leukemia incidence is observed in males of the weanling group exposed to the highest dose. Two cases of liver tumors have appeared; these were both in animals exposed prenatally to the highest dose and cross-fostered to an unexposed mother. 


\section{PLUTONIUM IN MINIATURE SWINE}

Investigator:

D. D. Mahlum

Technical Assistance:

J. L. Beamer

The last of the miniature pigs injected intradermal1y with 0.0016 to $5 \mu \mathrm{Ci}$ of ${ }^{239} \mathrm{Pu}$ approximately $11 \mathrm{yr}$ ago was necropsied, and tissues taken for histologic examination and radiochemical analyses. As with previous animals, there were minimal skin 1esions - small depressions with scar tissue built up around the depression. None of these animals showed gross evidence of skeletal tumors. The radiochemical data from these animals has been used to calculate radiation doses, particularly to the liver and to the skeleton. Doses to bone have exceeded those which resulted in a substantial incidence of osteogenic sarcoma in the University of Utah dogs. These data, derived from only six pigs, strongly indicate the need for additional long-term studies in a large animal other than the dog. A number of liver lesions, including tumors, were noted in these pigs; and attempts are being made to determine whether these are in excess of those normally expected.

\section{CALIFORNIUM STUDIES}

Investigator:

M. F. Sulzivan, J. L. Beamer, and A. C. Case

Technical Assistance:

A Ima Crosby and K. A. Strikwerda

Work commenced last year comparing the effects in Hanford Miniature swine of intracervical irradiation with either ${ }^{226} \mathrm{Ra}$ or ${ }^{252} \mathrm{Cf}$. Although this research is now being continued with support from a National Cancer Institute grant, some additional data have also been obtained with AEC funding. At the request of the Division of Biomedical and Environmental Research, the amount of $\mathrm{Na}$ activation was determined in animals exposed to ${ }^{252} \mathrm{Cf}$. It was found that a maximum of $2 \mathrm{nCi}$ per $\mathrm{m} 1$ was excreted in the urine following exposures that delivered from 2500 to 4000 rads to a 
point $2 \mathrm{~cm}$ lateral to tandem applicators containing four $12-\mu g{ }^{252} \mathrm{Cf}$ sources. The amount excreted was markedly influenced by the health of the animal; an animal in poor health retained $\mathrm{Na}$ regardless of the length of exposure to a neutron source. Also in support of this study, an RBE for ${ }^{252} \mathrm{Cf}$ neutrons is being determined in rats using changes in morphology and function of the G.I. tract as end points and comparing whole-body exposures to ${ }^{226} \mathrm{Ra}$ and ${ }^{252} \mathrm{Cf}$. No data are as yet available from the RBE study.

\title{
EINSTEINIUM AND BERKELIUM TOXICITY AND METABOLISM IN RATS
}

Investigators:

D. D. Mahlum, F. P. Hungate, and M. R. Sikov

Technical Assistance:

R. L. ChandZer, Joan O. Hess, and Jean D. Stearns

\begin{abstract}
Rats injected with ${ }^{253}$ Es as adults show greater mortality and osteosarcoma incidence than do rats injected as weanlings. The incidence of mammary tumors is increased in males injected as adults.
\end{abstract}

Rats intravenously injected with
253 Es as weanlings or adults have been maintained for observation of late effects. Injected doses ranged from 2 to $150 \mu \mathrm{Ci} / \mathrm{kg}$ in the weanlings and from 0.4 to $150 \mu \mathrm{Ci} / \mathrm{kg}$ in the adults. As reported last year, both acute and subacute lethality was substantially greater on an injected dose basis in the animals exposed as adults. This pattern continues. At $2 \mu \mathrm{Ci} / \mathrm{kg}$, almost half of the animals injected as adults are dead at 18 months postinjection, but only one fourth of the comparable group injected as weanlings are dead at this time. At the $10 \mu \mathrm{Ci} / \mathrm{kg}$ dose level, approximately one third of those injected as weanlings are dead, but essentially all of those injected as adults are dead. Since most of the radiation dose was delivered within 60 days postinjection, the effect of growth was minimal, and the adults and weanlings received essentially the same radiation dose to the skeleton at equal levels of injected radionuclide.

In the rats injected with $10 \mu \mathrm{Ci} /$ $\mathrm{kg}$ as adults, there is substantial incidence of bone tumors with a decline at higher doses. In the animals injected as weanlings, on the other hand, there is no increased 
bone tumor incidence below an injected dose leve1 of $100 \mu \mathrm{Ci} / \mathrm{kg}$, where results are somewhat obscured by early mortality. There appears to be an increase in leukemia incidence at $2 \mu \mathrm{Ci} / \mathrm{kg}$ in the adult-exposed group, which is not seen in the weanling-exposed group. There have also been a number of mammary tumors in the adult males injected with 2 or $10 \mu \mathrm{Ci} / \mathrm{kg}$.

Because of the early findings of chloroleukemia in this experiment, additional rats of the same strain
(Wistar) and of the Fischer strain as we 11 as mice were injected with doses in the lower portion of the range used in earlier experiments. only very limited results are as yet available from these experiments.

Absorption from the gastrointestinal tract of $\mathrm{Bk}$ or Es given in 0.01 $N$ HCl was about the same as absorption of $\mathrm{Pu}, 3 \times 10^{-3}$ percent. When the normality of the acid was increased to 0.5 , the uptake was increased nearly $100-$ fold.

\title{
EINSTEINIUM TOXICITY AND METABOLISM IN MINIATURE SWINE
}

\section{Investigators:}

H. A. Ragan, Beatrice J. McCZanahan, and Patricia L. Hackett

Technical Assistance:

Darlene Hunter, Martha Perkins, Eugenia T. Edmerson, Marizyn L. Greenwelz, and Glenda Vogt

\begin{abstract}
Most of a $3-\mu C i / k g$ dose of ${ }^{253}$ Es citrate was retained in bone and liver; about $6 \%$ was excreted in 7 days. Granulocytes and platelets were initially depressed but returned to control levels within 4 months postinjection. Total LDH values showed an immediate decrease but had recovered within 42 days, although LDH isoenzyme patterns differed from those of controls at 235 days.
\end{abstract}

Because a number of myeloid leukemias had been observed in rats injected with ${ }^{253}$ Es, we were interested to determine whether a similar effect could be produced in the miniature pig. It would be of particular value to leukemogenesis studies if leukemia could be induced in this animal in a shorter period of time than is required with ${ }^{90} \mathrm{Sr}$. Therefore 22 weanling (6-wk-old) miniature swine were injected intravenously with 3 $\mu \mathrm{Ci} / \mathrm{kg}$ of ${ }^{253}$ Es citrate. Ten animals were sacrificed at intervals following injection for measurement of Es 
distribution and retention in tissues. The remaining 12 animals will be maintained for observation of late effects.

At $24 \mathrm{hr}$ postinjection the liver contained the largest amount (15\%) of the injected ${ }^{253}$ Es. The femur contained $3.4 \%$, the kidney $0.49 \%$, the spleen $0.066 \%$ and the serum and whole blood $3.2 \times 10^{-4}$ percent per gram and $1.8 \times 10^{-4}$ percent per gram, respectively. By the fifteenth day the liver content had diminished to $7.7 \%$, but the femur remained essentially unchanged at $2.9 \%$. By the twenty-first day liver, femur and bone marrow were unchanged, but kidney levels had fallen to $0.19 \%$, and the spleen level was $0.1 \%$. Serum and whole-blood levels were too low to detect. The urinary excretion was much lower than observed with rats. Approximately $1.5 \%$ of the injected ${ }^{253}$ Es was excreted during the first $24 \mathrm{hr}$ (Figure 1), decreasing to 0.15 to $0.17 \%$ by Day 30 . Fecal excretion tended to be lower than urinary except for Days 2 and 4 . The cumulative excretion, urinary plus fecal, was $5.7 \%$ by the seventh day. At the

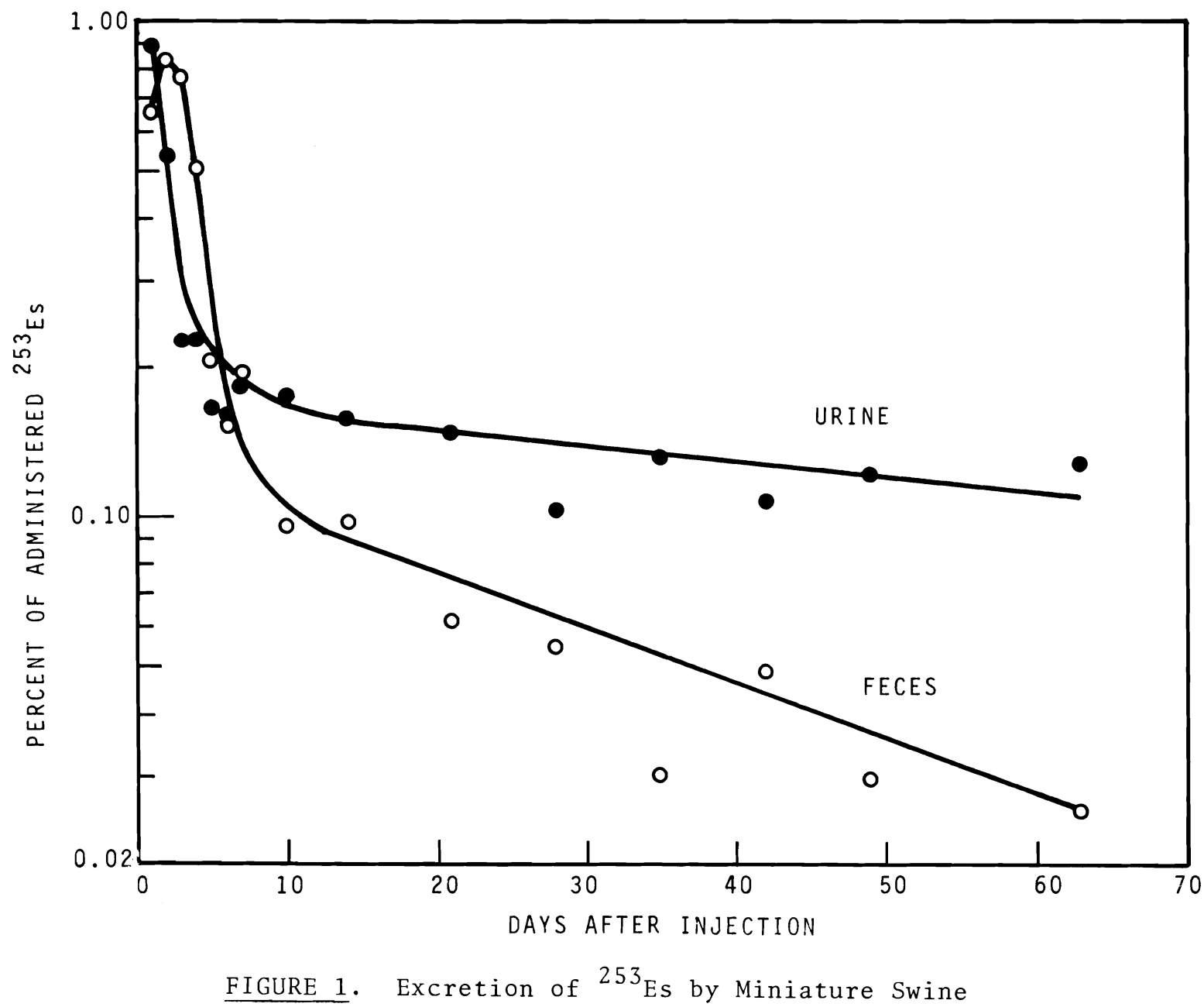


end of 2 months the daily urinary levels were about $0.1 \%$; and the fecal levels about $0.025 \%$.

Granulocyte levels were depressed by Day 4 after injection and attained a minimum at $25 \%$ of pre-exposure levels by Day 10. Lymphocyte values were somewhat lower than in the control pigs, but these values did not appear to be due to the isotope injection. Platelet numbers were depressed maximally by Day 25 and remained lower than controls for approximately 4 months. By 4 months postinjection the peripheral blood values were not different from the controls. The major changes in serum constituents appeared to be a decreased alkaline phosphatase level at 11 days postinjection and an immediate decrease in total lactic dehydrogenase $(\mathrm{LDH})$ activity. This decrease in LDH activity prompted an examination of the different isoenzymes making up the LDH component, and it was found that Fractions 2 and 3 accounted for most of the decrease. Further differences in the LDH isoenzyme pattern were found at 235 days postinjection. At this time LDH 1 had decreased, but LDH 2 and 3 had increased. These enzyme patterns will continue to be followed as a possible indicator of developing neoplasia since in man Fractions 2 and 3 are increased in granulocytic leukemia, and 2, 3, and 4 are increased in metaplasia. At 7 months postinjection, radiographs of the extremities and sku11 showed no detectable lesions, and a measured index of cortical bone to marrow space did not differ from similar measurements on control animals.

\title{
SKIN IRRADIATION STUDIES
}

\author{
Investigator: \\ D. D. Mahlum \\ Technical Assistance: \\ Joan 0. Hess and Jean D. Stearns
}

Observations continue on the skin of Hanford Miniature swine exposed 4 yr ago to graded radiation doses from ${ }^{204} \mathrm{~T} 1$ plaques. No changes have occurred during the past year. Areas of $0.5 \mathrm{~cm}^{2}$ and greater, exposed to doses of $6.25 \mathrm{krad}$ and higher, appear as thin, whitened areas. Animals ex- posed at 8 days of age show extensive enlargement of the exposed area, accompanied by considerable scar tissue formation.

A number of adult rats were exposed a year ago to as much as 50,000 rads from plaques of ${ }^{239} \mathrm{Pu}$. Since newborn rats were sensitive to carcinogenic effects of ${ }^{204} \mathrm{~T} 1$ radiation, 
the ${ }^{239} \mathrm{Pu}$ study was extended to include exposure of newborn rats with doses up to 50,000 rads. At the present time, gross damage has been minimal in animals of either age and is 1 imited to a slight outline of the exposed areas in a few animals.

\section{ELECTRON MICROSCOPIC STUDIES OF RADIATION EFFECTS}

\section{ON LIPID ABSORPTION}

\section{Investigator:}

J. C. Hampton

Technical Assistance:

B. Rosario

Radiation damage to the gastrointestinal tract was assessed using electron microscopic autoradiography to follow the absorption of lipid in the jejunum and ileum. A mixture of $0.2 \mathrm{ml}$ safflower oil containing 1.3 $\mathrm{mCi}{ }^{3} \mathrm{H}$-palmitic acid was administered to mice by stomach tube at various times after whole-body irradiation with $1500 \mathrm{R}$ of $\mathrm{X}$-ray. Electron microscopic examination of sections revealed a close correlation between the amount of lipid absorbed, the number of chylomicrons present, and the amount of ribosomes present in epithelial cells. The ileum was most affected and showed moderate to substantial reduction in ribosomes at 3 days postexposure to $1500 \mathrm{R}$; this finding correlated well with a sharp reduction in chylomicron synthesis. At 3.5 to 4 days postexposure, denuded villi began to develop, accompanied by nearly complete cessation of absorption and almost total depletion of ribosomes. Lacteals remained open on villi that retained their epithelial covering, but blood capillaries were usually occluded. Beginning between Days 2 and 3, glycogen depletion in liver became apparent, and by Day 4 was virtually complete.

Liver cells were atrophied and vacuolated at the time when the mice were moribund. The results indicate that ribosomal content of intestinal epithelial cells is an accurate index of functional capability. 


\title{
ELECTRON MICROSCOPIC STUDIES OF RADIATION EFFECTS
}

ON CAPILLARY PERMEABILITY

\author{
Investigator: \\ J. C. Hampton \\ Technical Assistance: \\ B. Rosario
}

\begin{abstract}
Histochemical localization of intravenously injected horseradish peroxidase was used to assess changes in vascular permeability induced by $x$-radiation. This approach has been shown to be a sensitive indicator of cell viability not only for vascular components but also for parenchymal cells in vivo.
\end{abstract}

Mice were exposed to $1500 \mathrm{R} \mathrm{X-}$ radiation and injected with horseradish peroxidase (HRP) about 2 min prior to sacrifice at intervals of 1 , $2,3,3.5$ and 4 days postexposure. Horseradish peroxidase is an effective, low molecular weight, dense tracer which can be easily detected in electron micrographs and which normally leaves the vascular system via capillary fenestrae, gaps between endothelial cells, and by pinocytosis. Horseradish peroxidase provides a way by which exchange between plasma and tissue fluid can be studied. Damaged cells are apparently unable to exclude HRP from their cytoplasm and are, therefore, stained black by the HRP reaction product resulting from incubation of tissue slices in 3 - 3' diaminobenzidine. Tracer studies revealed damage to capillaries, as evidenced by blackened endothelial cells, as early as Day 2 postexposure. No evidence was found that would suggest increased leakage of HRP through endothelial fenestrae or between endothelial cells. Heavy deposits in the internal elastic lamina of small arteries were also observed, suggesting that elements of the vascular system other than the endothelium are subject to radiation damage. This is further substantiated by heavy deposits in arterial smooth muscle cells when other elements of the same vessel are free of reaction product (Figure 1). Endothelial damage not dependent upon HRP for detection was observed and consisted of disrupted and detached endothelial cells.

An important result of this work was the finding that parenchymal cells of various organs either damaged by radiation or undergoing norma1 degeneration processes, for example, kidney tubule cells and intestinal epithelial cells, were freely permeated by HRP (Figure 2). Thus, a method is available for assessing cell viability at the electron microscope level analogous to 


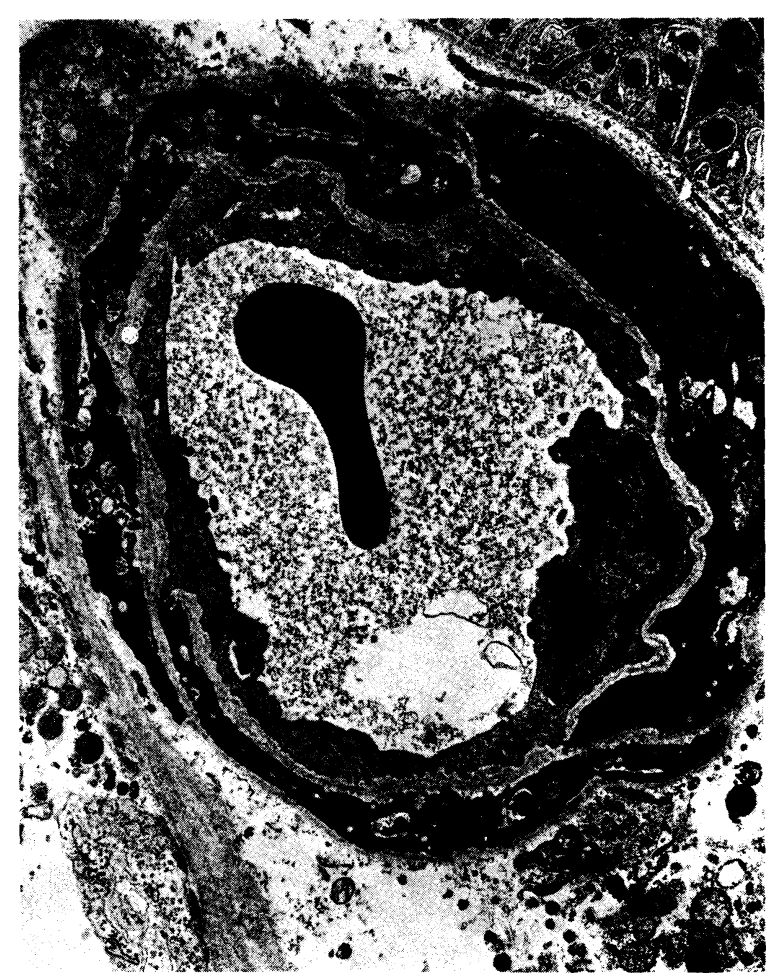

$6,000 x$

FIGURE 1. HRP Permeability of Nonviable Smooth Muscle Cells in a Kidney Arteriole. HRP reaction product stained cells black.

permeation of damaged cells by organic dyes when applied to living cel1 populations examined with the light microscope. This method is more useful than organic dyes because

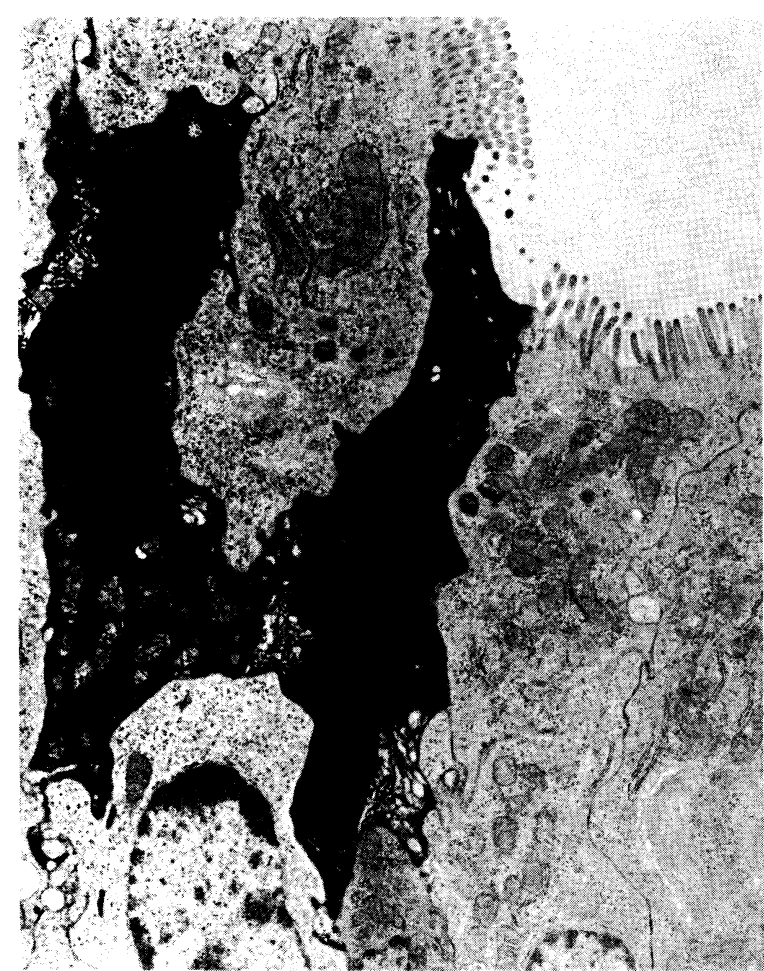

$6,750 \mathrm{X}$

FIGURE 2. HRP Permeability of Nonviable Intestinal Epithelial Cells. HRP reaction product stained cells black.

HRP can be applied in vivo; it is quickly distributed throughout the animal, and it can be used with any organ or tissue. 


\section{STUDIES WITH A PROTECTIVE AGENT}

Investigator:

J. C. Hampton

Technical Assistance:

B. Rosario

Preliminary results of tests with Compound WR 2721 in mice indicate good protection at $1500 \mathrm{R}$ but no protection at $2500 \mathrm{R}$.

Compound WR 2721, S-2 (3 aminopropylamino) ethyl phosphothioic acid hydrate, was supplied by walter Reed Army Institute of Research. Six hundred $\mathrm{mg} / \mathrm{kg}$ doses were administered intraperitoneally to mice $1 \mathrm{hr}$ prior to exposure to $1500 \mathrm{R}$ and $2500 \mathrm{R}$ whole-body radiation. Control animals not injected with WR 2721 died between Days 4 and 7 postexposure (Figure 1). Drug-treated animals were permitted to survive up to 10 days when they were sacrificed for study. At the time of sacrifice, the protected animals appeared normal. Examination of the small intestine at the time of sacrifice of drug-treated mice revealed mild dilation and shortening of crypts but no serious defects were observed on the villi. The drug is toxic since injected, unirradiated mice remained inactive for periods up to $4 \mathrm{hr}$. Histologic examination did not reveal changes in the intestine during this period nor at other intervals up to 10 days postinjection (Figure 2). In order to evaluate the mode of radioprotection, the experiments were repeated using safflower oil as a test of functional capability; HRP was injected to assess vascular permeability and cell viability; and ${ }^{3} \mathrm{H}-$ thymidine, along with colcimide, was used to study cell proliferation effects. These tissues are currently being processed for study. Incomplete results indicate that WR 2721 treated mice showed no impairment of gut function nor any depression of proliferative activity in the gut epithelium. WR $2721+1500$ R-treated mice did not show depression of absorptive capability but did show moderate, but not severe, depression of proliferative activity in the crypts. No results are available as yet from experiments dealing with vascular permeability and cell viability as determined with HRP. 


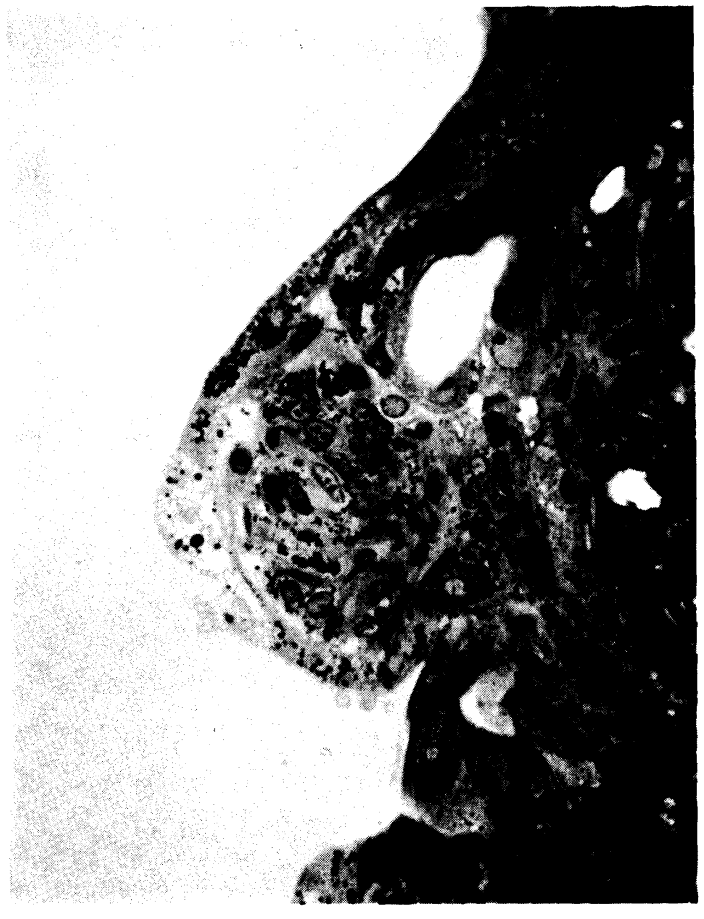

$420 \mathrm{X}$

FIGURE 1. Remains of an Intestinal Villus in a Mouse Exposed to $1500 \mathrm{R}$ X-rays but Unprotected with WR 2721 . Epithelial cells are low cuboidal and squamous, showing severe degeneration.

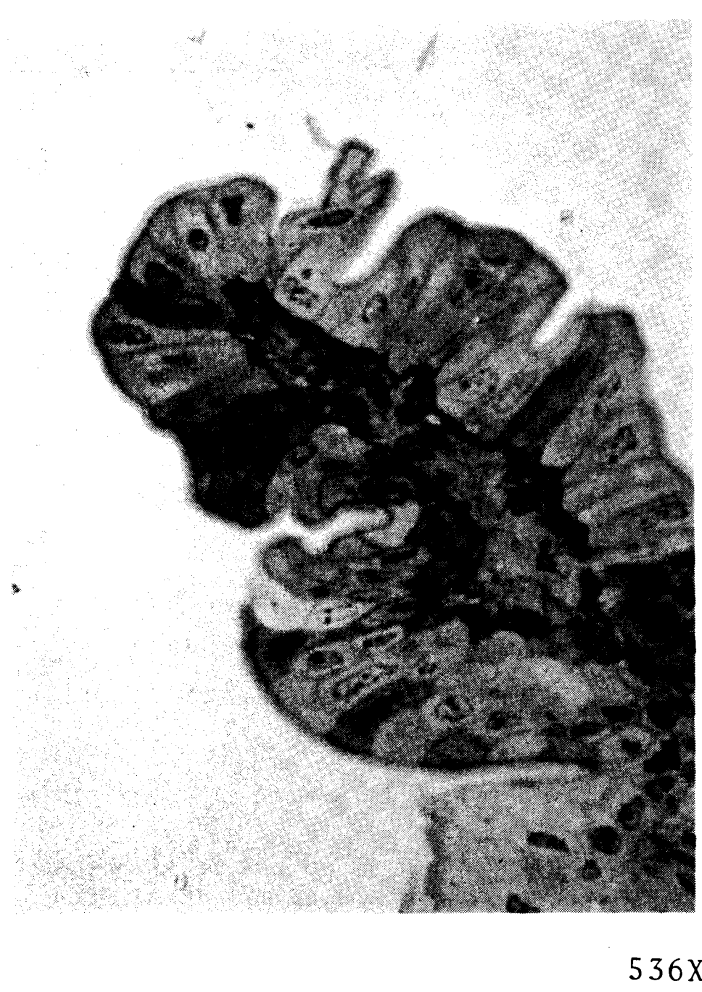

FIGURE 2. Tip of an Intestina 1 Villus of a Mouse 4 Days Postexposure to $1500 \mathrm{R} \mathrm{X}$-rays. The mouse was injected with WR 2721 about $1 \mathrm{hr}$ before $\mathrm{X}$-ray exposure. The epithelial cells have retained their tall, columnar shape, showing no cel1 degeneration. 
TOXICOLOGY OF INHALED PLUTONIUM AND TRANSPLUTONIUM ELEMENTS

The project combines under one title essentially all of our inhalation studies except those concerned with uranium miners. It includes activities previously funded under the titles "Inhalation Studies," "Space Nuclear Systems Studies," and "Low-Level Plutonium Inhalation Studies in Beagles." It does not include studies of the therapeutic removal of inhaled materials, which were previously funded in the "Inhalation Studies" project.

The activities within this large project are subdivided into four categories:

(1) Dose-Effect Relationship Studies - life-span research with rats and dogs

(2) Kinetics and Dosimetry Studies - deposition, retention, translocation, and excretion of the inhaled radionuclides

(3) Biological Effects Studies - determination of critical effects, organs, and tissues, and

(4) Aerosol Technology Studies - development of aerosol generation, sampling, and characterization procedures.

Data from experiments in all of these areas are included among the reports that follow.

\section{PUBLICATIONS}

BALLOU, J. E. and J. O. HESS. Biliary Plutonium Excretion in the Rat. Health Phys., vol. 22, p. 369. 1972.

BALLOU, J. E. and J. B. HURSH. The Measurement of Thoron in the Breath of Dogs Administered Inhaled or Injected Tho2. Health Phys., vol. 22 , p. 159 .

BALLOU, J. E. and W. G. MORROW. The Disposition and Long-Term Effect of Intratracheally Instilled $253_{E s}$ in Rats. Health Phys., vol. 23, p. 418. (Abstract). 1972 .
BALLOU, J. E., J. F. PARK, and W. G. MORROW. On the Metabolic Equivalence of Ingested, Injected and Inhaled 239 Pu Citrate. In: W. J. Bair and R. C. Thompson (Eds.), The Biological Implications of the Transuranium Elements, Health Phys., vol. 22 , p. 857. 1972 .

CRAIG, D. K., J. M. THOMAS, J.R. DECKER, and J. F. PARK. Alveolar Deposition of $239 \mathrm{PuO}_{2}$ Aerosols in Beagle Dogs as a Function of Respiration and Aerosol Parameters. Health Phys., vol. 22, p. 845. 1972. 
CRAIG, D. K., R. L. BUSCHBOM, J. P. HERRING, and J. F. PARK. Relationships Between the Size Distribution of $239 \mathrm{PuO}_{2}$ Aerosols, Aerosol Concentration and Nebulizer Suspension Concentration. Health Phys., vol. 22, p. 845. (Abstract). 1972.

DECKER, J. R. and D. K. CRAIG. Alpha Aerosol Monitor: Rapid Determination of Low-Level Alpha Aerosol Concentrations. Health Phys., vol. 23,

p. 429. (Abstract). 1972 .

HUNGATE, F. P. and D. W. BAXTER. $253 E s$ and $249 B k$ Uptake and Distribution in Rats. Radiat. Res., vol. 51, p. 542. (Abstract). 1972.

HUNGATE, E. P., J.E. BALLOU, D. D. MAHLUM, M. KASHIMA, V. H. SMITH, C. L. SANDERS, D. W. BAXTER, M. R. SIKOV, and R. C. THOMPSON. Preliminary Data on $253 \mathrm{Es}$ and $249 \mathrm{BK}$ Metabolism in Rats. Health Phys., vol. 22 , p. 653. 1972 .

MCDONALD, K. E., J. F. PARK, R.J. $O L S O N, R$. H. BUSCH, and C. L. SANDERS. Removal of Inhaled $239 \mathrm{PuO}_{2}$ from Beagle Dogs by Pulmonary Lavage. Health Phys., vol. 23, p. 425. (Abstract). 1972 .

PARK, J. F., W. J. BAIR, and R. H. BUSCH. Progress in Beagle Dog Studies with Transuranium Elements at Battelle-Northwest. In: $W$. J. Bair and $R$. C. Thompson $\overline{(E} d s$.$) , The$ Biological Implications of the Transuranium Elements. Health Phys. vol. 22, p. 803. 1972 .
SANDERS, C. L. Carcinogenesis of Inhaled 238Pu Derived from Crushed Microspheres. Radiat. Res., vol. 51, p. 492. (Abstract). 1972 .

SANDERS, C. L. Deposition Patterns and Toxicity of Transuranium Elements in Lung. In: W. J. Bair and R. C. Thompson ( $\overline{E d s .), ~ T h e ~ B i o l o g i c a l ~ I m p l i-~}$ cations of the Transuranium Elements, Health Phys., vol. 22, p.607. 1972.

SANDERS, C. L. Production of $A b-$ dominal Mesotheliomas in Rats with $239 \mathrm{PuO}_{2}$ and Chrysotile Asbestos. Health Phys., vol. 23, p. 418. (Abstract). 1972 .

SANDERS, C. L., T. A. JACKSON, and $R$. R. ADEE. Induction of Mesotheliomas and Sarcomas by Intra-Abdominal Deposits of $239 \mathrm{PuO}_{2}$ Particles. In: W. J. Bair and R. C. Thompson (Eds.), The Biological Implications of the Transuranium Elements, Health Phys. vol. 22, p. 755. 1972.

THOMPSON, R. C. and W. J. BAIR, Eds. Hanford Symposium on the Biological Implications of the Transuranium Elements. Health Phys., vol. 22. 1972 .

THOMPSON, R. C., J. F. PARK, and W. J. BAIR. Some Speculative Extensions to Man of Animal Risk Data on Plutonium. In: B. J. Stover and W. S. S. Jee (Eds.), Radiobiology of Plutonium. J. W. Press, University of Utah, Salt Lake City. 1972.

TOMBROPOULOS, E. G. Palmitate Incorporation into Lipids by Lung Subcellular Fractions. Biochem. J. (In Press). 1972. 


\section{DOSE-EFFECT STUDIES WITH INHALED PLUTONIUM IN RATS AND DOGS}

Investigators:

J. E. Balzou, D. K. Craig, J. F. Park,

H. A. Ragan, and C. L. Sanders

Technical Assistance:

J. S. Barnett, E. F. Blanton, R. D. Carmichael,

D. L. Catt, J. N. Fitzner, D. M. Meier,

W. G. Morrow, M. D. Snyder, G. L. Webb,

and $E$. L. Wierman

To determine 1 ife-span dose-effect relationships of inhaled ${ }^{239} \mathrm{Pu}$ and ${ }^{238} \mathrm{Pu}$, rats and beagle dogs are being exposed to ${ }^{238} \mathrm{Pu}$ and ${ }^{239} \mathrm{Pu}$ oxide, and rats, to ${ }^{238} \mathrm{Pu}$ and ${ }^{239} \mathrm{Pu}$ nitrate.

Eighteen-month old beagles were exposed to ${ }^{239} \mathrm{PuO}_{2}$ aerosols nebulized from water suspensions of ${ }^{239} \mathrm{PuO}_{2}$ (mean AMAD $2.3 \mu \mathrm{m}$, mean GSD 1.9) between October 1970 and November 1971. The ${ }^{239} \mathrm{PuO}_{2}$ was prepared by calcining the oxalate at $750^{\circ} \mathrm{C}$ for $2 \mathrm{hr}$. One hundred-twenty dogs were selected for long-term studies; 12 will be sacrificed to obtain $\mathrm{Pu}$ pulmonary retention, translocation, and pathology in low-level dogs that do not die early due to $\mathrm{Pu}$-induced causes, and 108 were assigned to 1 ife-span doseeffect studies (Table 1). Plutonium analyses of tissues have been completed on 10 dogs sacrificed 1 to 20 wk after exposure and on two dogs in the high level group that were euthanized when death was imminent due

\begin{tabular}{|c|c|c|c|c|c|c|}
\hline \multirow[b]{3}{*}{ Dose Level Group } & \multicolumn{6}{|c|}{ Dose-Effect Studies with Inhaled ${ }^{239} \mathrm{PuO}_{2}$} \\
\hline & \multicolumn{2}{|c|}{ Number of Dogs } & \multicolumn{4}{|c|}{ Initial Alveolar Deposition ${ }^{a}$} \\
\hline & $M$ & $\mathrm{~F}$ & $n C i^{b}$ & \multicolumn{3}{|c|}{$\underline{n C i / g \text { Lung }}{ }^{b}$} \\
\hline 0 & 10 & 10 & 0 & 0 & & \\
\hline 1 & 10 & 10 & $3.5 \pm$ & 0.04 & \pm & 0.02 \\
\hline 2 & 10 & 10 & $22 \pm$ & 0.3 & \pm & 0.05 \\
\hline 3 & 10 & 10 & $79 \pm 14$ & 1.1 & \pm & 0.2 \\
\hline 4 & 10 & 10 & $303 \pm 62$ & 3.9 & \pm & 0.7 \\
\hline 5 & 10 & 10 & $1083 \pm 167$ & 14.1 & \pm & 2.0 \\
\hline \multirow[t]{2}{*}{6} & 3 & 5 & \pm 3282 & 85.6 & \pm & 43.9 \\
\hline & 63 & 65 & & & & \\
\hline \multicolumn{7}{|c|}{$\begin{array}{l}\text { astimated from external thorax counts at } 14-\text { and } \\
30-\text { day postexposure and estimated lung weights. } \\
\text { bean } \pm 95 \% \text { confidence interval around the mean. }\end{array}$} \\
\hline
\end{tabular}


to $\mathrm{Pu}$-induced respiratory insufficiency during the first postexposure year. Plutonium analyses of tissues have also been done on one dog from the lowest dose level in the scheduled sacrifice group to compare pulmonary retention and translocation data (Table 2).

Dogs sacrificed during the 7- to 30-day postexposure period had more than $98 \%$ of the final Pu body burden in the lungs except for Dog 920M with a total body burden of $11 \mathrm{nCi}$; this dog showed more translocation to muscle, skeleton, and all remaining tissues than other dogs. Similar increased translocation appeared in Dog $849 \mathrm{~F}$ sacrificed 385 days after exposure with a final body burden of $0.65 \mathrm{nCi}$. Tissues from these and other very low-level exposure dogs will be recounted to confirm the apparent higher translocation. Since $>98 \%$ of the $\mathrm{Pu}$ was in the lungs and thoracic lymph nodes during the 7- to 30-day postexposure period, in vivo thorax counting during the 14- to 30day postexposure period was used to obtain estimates of initial alveolar burden as listed in Table 1 .

During the first postexposure year, 11 to $29 \%$ of the $\mathrm{Pu}$ was translocated from the lung to the thoracic lymph nodes with little translocation to other tissues. Except for Dog $849 \mathrm{~F},>99 \%$ of the $\mathrm{Pu}$ was in the lungs and thoracic lymph nodes 1 yr after exposure. In the dogs sacrificed at about 140 days, the final body burden was $92 \pm 4 \%$ of the $\mathrm{Pu}$ initially deposited. The initial alveolar deposition (8-day postexposure body burden) was $94 \pm 6 \%$ of the $\mathrm{Pu}$ initially deposited. About $75 \%$ of the tota 1 excreted $\mathrm{Pu}$ was excreted during the first $\&$ postexposure days, with $99 \%$ of this in the feces. The mean whole-body retention half-time of the alveolar-deposited $\mathrm{Pu}$ was $4900 \pm 3800$ days, and the lung retention halftime was $1500 \pm 700$ days.

TABLE 2. Tissue Distribution of Inhaled $\mathrm{Pu}$ in Dogs After Inhalation of $239 \mathrm{PuO}_{2}$ Aerosols.

Dog Number

Time After Exposure (Days)

Lungs

Thoracic Lymph Nodes a

Liver

Skeleton

Muscle

Skin

AlI Remaining Tissues

Final Body Burden (nCi)

Feces ( $\mathrm{nCi}$ )

Urine (nCi)

Total Excreted (nci)

Total Initial Alveolar Burden $(n c i)^{b}$

Whole-Body Retention Half-Time (Days)b Lung Retention Half-Time (Days)b
Percent of Final Body Burden

$\begin{array}{rrrrrr}\frac{478 \mathrm{M}}{7} & \frac{435 \mathrm{~F}}{7} & \frac{816 \mathrm{M}}{15} & \frac{918 \mathrm{M}}{28} & \frac{920 \mathrm{M}}{29} & \frac{913 \mathrm{M}}{30} \\ & & & & & \\ 98.00 & 99.66 & 99.52 & 98.75 & 93.62 & 98.56 \\ 0.15 & 0.10 & 0.12 & 0.82 & 0.47 & 1.08 \\ 0.24 & 0.00 & 0.00 & 0.11 & 0.08 & 0.03 \\ 0.08 & 0.03 & 0.03 & 0.08 & 0.61 & 0.05 \\ 0.56 & 0.05 & 0.05 & 0.00 & 3.68 & 0.22 \\ 0.57 & 0.15 & 0.09 & 0.02 & 0.99 & 0.03 \\ 0.40 & 0.01 & 0.19 & 0.22 & 0.55 & 0.03 \\ 293.1 & 3840.5 & 398.5 & 73.6 & 10.9 & 4849.4\end{array}$$$
\begin{array}{r}
93.79 \\
5.73 \\
0.01 \\
0.09 \\
0.12 \\
0.01 \\
0.25
\end{array}
$$$$
\frac{709 M}{141}
$$$$
\frac{734 M}{141}
$$

97.38
2.20
0.00
0.05
0.04
0.00
0.33

96.01
3.36
0.01
0.05
0.06
0.01
0.50

$\begin{array}{lll}1682.3 & 1726.4 \quad 914.4\end{array}$

$\begin{array}{llll}49.3 & 230.5 & 119.7 & 114.5\end{array}$

$\begin{array}{rrrr}49.3 & 230.5 & 119.7 & 114.5 \\ 1.2 & 2.5 & 1.7 & 0.7 \\ 50.5 & 233.0 & 121.4 & 115.2\end{array}$

$\begin{array}{rrrr}1732.8 & 1959.4 & 1035.8 & 1626.2 \\ 1702.0 & 1761.0 & 948.0 & 1551.0\end{array}$

$\begin{array}{llll}8210 & 4870 & 2690 & 3770\end{array}$ $\frac{747 \mathrm{~F}^{\mathrm{C}}}{358} \quad \frac{906 \mathrm{~F}^{\mathrm{C}}}{383} \quad \frac{849 \mathrm{~F}}{385}$

94.79
4.72
0.01
0.00
0.05
0.00
0.43

1511.0
114.5
0.7
115.2
626.2
551.0
0
1770
130

$\begin{array}{lll}71.16 & 88.13 & 79.21\end{array}$

$\begin{array}{rrr}28.54 & 11.62 & 15.32 \\ 0.01 & 0.03 & 0.04\end{array}$

$\begin{array}{lll}0.01 & 0.03 & 0.04 \\ 0.07 & 0.05 & 2.60\end{array}$

$\begin{array}{lll}0.10 & 0.08 & 0.55\end{array}$

$\begin{array}{lll}0.01 & 0.00 & 0.60 \\ 0.11 & 0.09 & 1.68\end{array}$

$5434.4 \quad 6154.2 \quad 0.65$

a. Tracheobronchia1, mediastinal and sternal $1 y$ mph nodes

b. Estimated from 8-day postexposure body burden determined from whole-

body retention curve obtained by Puanalyses of all tissues at sacri-

fice and summation of all Pu in daily and weekly excreta samples

c. Euthanized when death was imminent due to respiratory insufficiency 
The clinical signs in dogs euthanized when death was imminent were similar to those previously reported and included increased respiration rate, anoxemia, hypoxemia, bodyweight loss associated with pulmonary fibrosis and lymphopenia. A11 of the dogs in the highest dose-leve 1 group show increased respiration rate and subnormal body weights. The groups with mean initial alveolar burdens $>300 \mathrm{nCi}$ had lymphopenia during the first year after exposure, while the $80 \mathrm{nCi}$ and lower dose groups were similar to the controls (Figure 1).

In preparation for the ${ }^{238} \mathrm{PuO}_{2}$ dog exposures, six dogs were exposed to $238 \mathrm{PuO}_{2}$ that was prepared in the same manner as the ${ }^{239} \mathrm{PuO}_{2}$. $\mathrm{Plu}$ tonium oxalate was calcined at $750^{\circ} \mathrm{C}$ for $2 \mathrm{hr}$, and the product suspended in water at a concentration of 2 to $3 \mathrm{mg} \mathrm{PuO}_{2} / \mathrm{ml}$. As was the case with $239 \mathrm{PuO}_{2}$, the water suspension of $238 \mathrm{PuO}_{2}$ was stored until required for exposure at which time suspensions of suitable concentration were prepared from the stock. Aerosols were generated by nebulizing these suspensions. The ultrafilterability of the ${ }^{238} \mathrm{PuO}_{2}$ stock suspension 6 months after preparation was $25 \%$; and dogs exposed to aerosols (mean AMAD $0.9 \mu \mathrm{m}$, mean GSD 2.6) of this plutonium had 17 to $45 \%$ of the $\mathrm{Pu}$ body burden in the skeleton, 4 to $11 \%$ in the liver, and 30 to $75 \%$ in the lungs and thoracic lymph nodes when sacrificed 27 to 92 days postexposure (Table 3). The ultrafilterability of ${ }^{239} \mathrm{PuO}_{2}$ suspension had remained stable ranging from 0.1 to $0.2 \%$ over a 24-month period after preparation, and dogs exposed to ${ }^{239} \mathrm{PuO}_{2}$ during this time and sacrificed 1 to 12 months after exposure had $>94 \%$ of the body burden at death in the lungs and thoracic lymph nodes (Table 2).

The X-ray diffraction analyses of the ${ }^{239} \mathrm{PuO}_{2}$ stored in water suspension for 24 months and of freshly prepared ${ }^{238} \mathrm{PuO}_{2}$ yielded the expected peaks, but ${ }^{238} \mathrm{PuO}_{2}$ that had been in water suspension for 9 months showed no X-ray peaks. It appeared that radiation damage due to radiolysis had caused the ${ }^{238} \mathrm{PuO}_{2}$ to change to a more soluble form in the water suspension.

Dogs exposed to freshly prepared $238 \mathrm{PuO}_{2}$ (mean AMAD $2.2 \mu \mathrm{m}$, mean GSD 2.3) with $0.2 \%$ ultrafilterability showed more than $96 \%$ of the Pu body burden in the lungs and thoracic lymph nodes 30 to 78 days after exposure (Table 3). The ultrafilterability of the water suspension used for exposure changed from 0.2 to $16 \%$ over the 60-day postexposure period.

Table 4 shows ${ }^{238} \mathrm{Pu}$ tissue distribution in dogs 2 to 3 yr after inhalation of ${ }^{238} \mathrm{PuO}_{2}$ compared to dogs sacrificed at similar times after inhalation of ${ }^{239} \mathrm{PuO}_{2}$. The much greater translocation of the ${ }^{238} \mathrm{Pu}$, despite the low ultrafilterability and the fresh state of the water suspension employed in generating the aerosol, suggests that solubilization of the $238 \mathrm{PuO}_{2}$ occurs to a significant degree within the dog, as well as in the water suspension. Five of 17 dogs surviving 4 yr after exposure to $238 \mathrm{PuO}_{2}$ calcined at $350^{\circ} \mathrm{C}$ or to crushed ${ }^{238} \mathrm{PuO}_{2}$ microspheres were sacrificed during the 4 to $5 \mathrm{yr}$ 


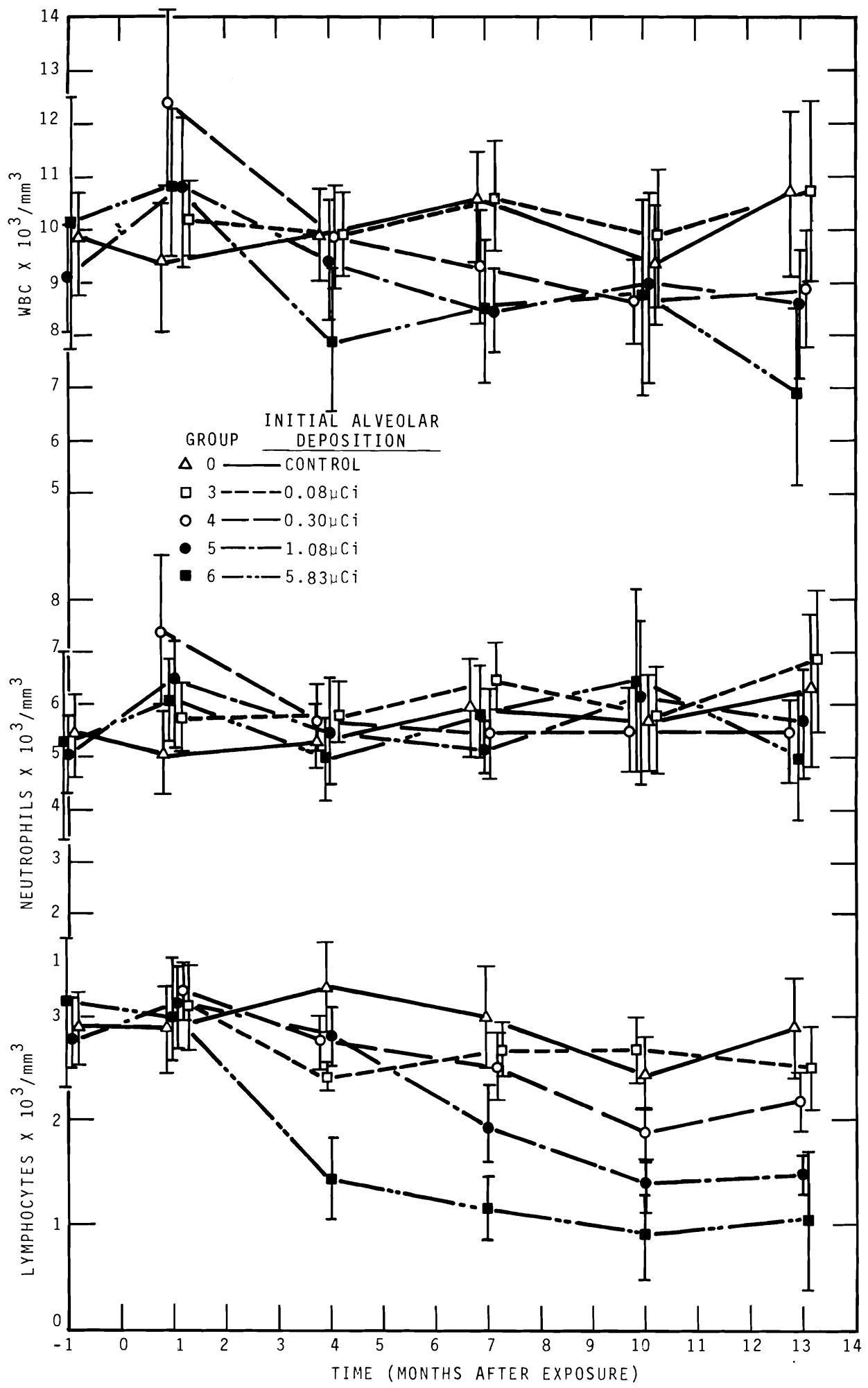

FIGURE 1. Leucocyte Values in Beagles After Inhalation of $239 \mathrm{PuO}_{2}$ (means $\pm 95 \%$ confidence interval) 
TABLE 3. Tissue Distribution of Inhaled $\mathrm{Pu}$ in Dogs After Inhalation of $238 \mathrm{Pu}$ Aerosols from "Aged" and "Fresh" Water Suspensions of $238 \mathrm{PuO}_{2}$

\begin{tabular}{|c|c|c|c|c|c|c|c|c|c|c|c|}
\hline \multirow[b]{2}{*}{ Dog Number } & \multicolumn{6}{|c|}{ "Aged" ${ }^{238} \mathrm{PuO}_{2}{ }^{\mathrm{a}}$} & \multicolumn{5}{|c|}{ "Fresh" ${ }^{238} \mathrm{PuO}_{2}{ }^{\mathrm{b}}$} \\
\hline & $\underline{917 \mathrm{~F}}$ & $\underline{956 \mathrm{~F}}$ & $\underline{936 \mathrm{~F}}$ & $958 \mathrm{M}$ & $\underline{957 M}$ & $1001 \mathrm{~F}$ & $\underline{924 M}$ & $\underline{933 \mathrm{~F}}$ & $\underline{942 M}$ & $\underline{935 \mathrm{M}}$ & $\underline{922 F}$ \\
\hline Time After Exposure (Days) & 27 & 29 & 37 & 91 & 92 & 92 & 30 & 55 & 55 & 78 & 78 \\
\hline Lungs & 74.6 & 55.7 & 59.3 & 55.9 & 49.8 & 22.7 & 97.7 & 93.2 & 91.9 & 92.2 & 89.5 \\
\hline Thoracic Lymph Nodesc & 0.3 & 0.0 & 2.4 & 6.2 & 4.7 & 9.3 & 0.7 & 4.9 & 5.0 & 3.9 & 6.0 \\
\hline Liver & 3.6 & 7.8 & 11.2 & 10.2 & 9.7 & 11.6 & 0.3 & 0.4 & 0.8 & 0.7 & 0.9 \\
\hline Skeleton & 17.4 & 28.9 & 23.0 & 23.0 & 30.2 & 48.2 & 0.5 & 0.8 & 1.1 & 1.3 & 2.2 \\
\hline Muscle & 1.5 & 1.6 & 1.3 & 2.9 & 1.9 & 6.0 & 0.4 & 0.3 & 0.8 & 1.4 & 0.9 \\
\hline Skin & 0.2 & 3.5 & 0.5 & 0.3 & 1.9 & 0.7 & 0.2 & 0.2 & 0.1 & 0.2 & 0.1 \\
\hline A11 Remaining Tissue & 2.4 & 2.5 & 2.3 & 1.5 & 1.8 & 1.5 & 0.2 & 0.2 & 0.3 & 0.3 & 0.4 \\
\hline Final Body Burden ( $\mathrm{nC} i$ ) & 48.8 & 125.8 & 3120.3 & 788.6 & 22.1 & 43.8 & 151.1 & 191.5 & 58.5 & 171.3 & 82.3 \\
\hline \multicolumn{12}{|c|}{ 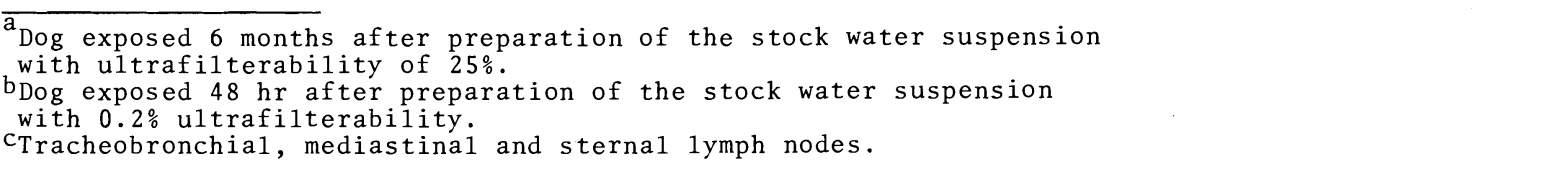 } \\
\hline
\end{tabular}

TABLE 4. Tissue Distribution of $\mathrm{Pu}$ in Beagles 2 to $3 \mathrm{Yr}$ After Inhalation of $239 \mathrm{PuO}_{2}$ and $238 \mathrm{PuO}_{2}$

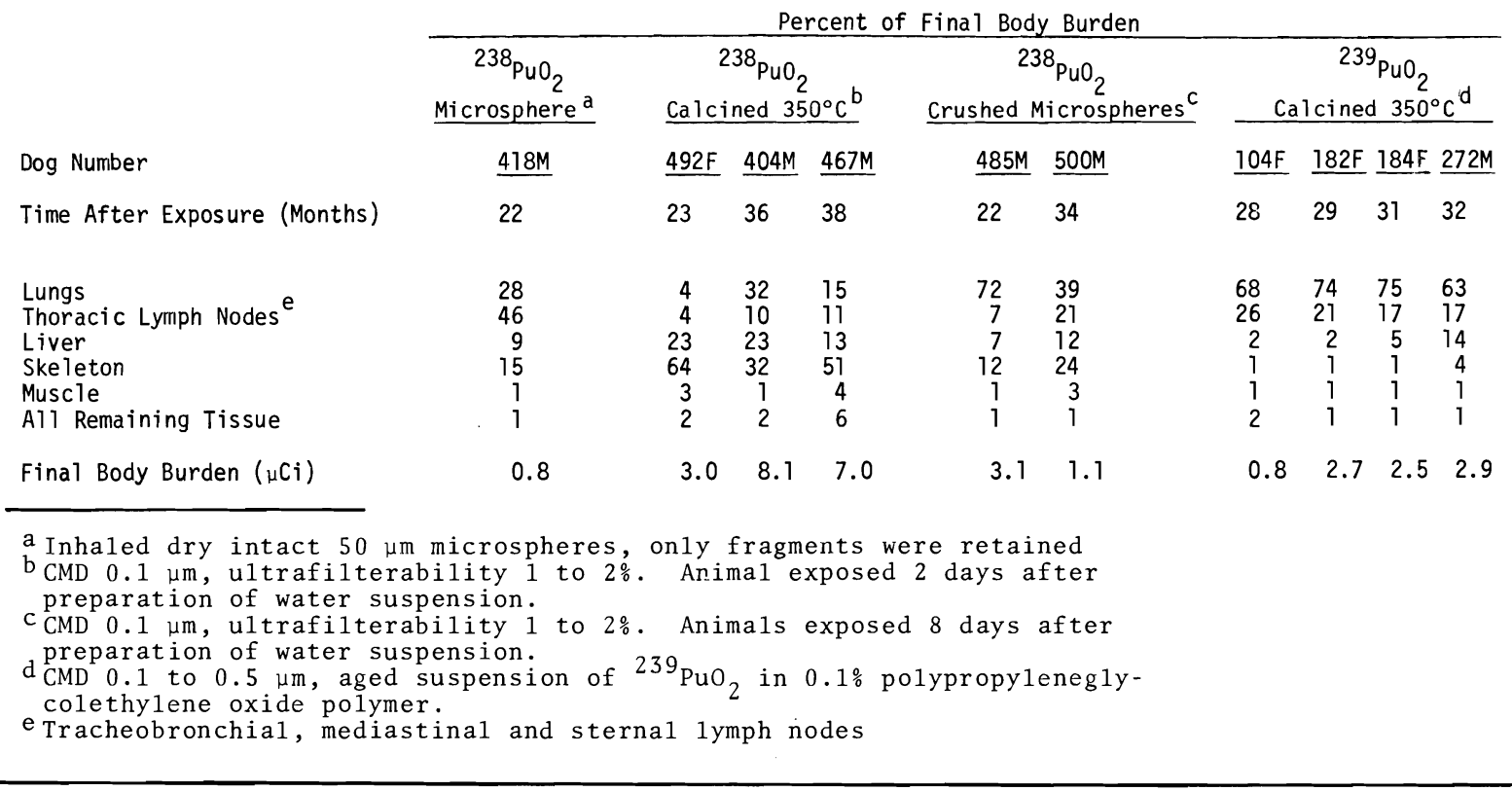


postexposure period due to osteosarcoma. Plutonium analyses and histopathologic study of tissues from these animals are in progress. Dogs on the ${ }^{238} \mathrm{PuO}_{2}$ low-leve1 dose-effects life-span study are being exposed to so-called pure $\mathrm{Pu}$ oxide (PPO). This material is the normal Savannah River product with $80 \pm 2$ atom percent ${ }^{238} \mathrm{Pu}$. The PPO is ${ }^{238} \mathrm{PuO}_{2}$ that was calcined from the oxalate at $700^{\circ} \mathrm{C}$ and subjected to $\mathrm{H}_{2}{ }^{16} \mathrm{O}$ steam in Ar exchange at $800^{\circ} \mathrm{C}$ for $96 \mathrm{hr}$. The material obtained from Los Alamos Scientific Laboratory was ball milled to particles with an MMD of $2.8 \mu \mathrm{m}$. Ten dogs were exposed to aerosols nebulized from freshly prepared water suspensions (ultrafilterability $0.02 \%$, mean AMAD $1.9 \mu \mathrm{m}$, mean GSD 1.7) and sacrificed for retention and translocation studies $7,28,60$ and 90 days after exposure. For comparison, 10 dogs were also exposed to aerosols nebulized from freshly prepared water suspensions (ultrafilterability $0.25 \%$, mean AMAD $2.1 \mu \mathrm{m}$, mean GSD 1.7) of ${ }^{238} \mathrm{PuO}_{2}$ cermet (PMC) and sacrificed at similar postexposure periods. This PMC, $3 \%$ Mo by weight, is representative of fuels from the
Mound Laboratory production site and was further treated by ball milling at the Los Alamos Scientific Laboratory to particles with an MMD of $3.6 \mu \mathrm{m}$. Plutonium analyses have been completed on dogs to 28 days postexposure showing $>90 \%$ of both materials remaining in the lungs (Table 5).

Exposure of approximately 110 dogs to ${ }^{238} \mathrm{Pu}^{16} \mathrm{O}_{2}$ is now in progress. These dogs will have burdens similar to those shown in Table 1 and will afford a comparison of the life-span dose-effect relationship of inhaled ${ }^{239} \mathrm{PuO}_{2}$ and ${ }^{238} \mathrm{PuO}_{2}$. The lowest dose-level group is equivalent to the dose that delivers u $15 \mathrm{rem} / \mathrm{yr}$ to the human lung.

Rats have been exposed to ${ }^{238} \mathrm{PuO}_{2}$ and ${ }^{239} \mathrm{PuO}_{2}$ aerosols so that 1 ife-span dose-effect results will be obtained for two species with a large normal life-span difference and for two $\mathrm{Pu}$ isotopes with different specific activities. Rats have also been exposed to ${ }^{238} \mathrm{Pu}$ nitrate and ${ }^{239} \mathrm{Pu}$ nitrate aerosols to compare the lifespan dose-effect relationship of ${ }^{238} \mathrm{Pu}$ and ${ }^{239} \mathrm{Pu}$ nitrate with inhaled ${ }^{239} \mathrm{Pu}$ and ${ }^{238} \mathrm{Pu}$ oxide. The experimental design for these rat studies is shown in Table 6 . 
TABLE 5. Tissue Distribution of Inhaled Pu in Dogs After Inhalation of $238 \mathrm{Pu}^{16} \mathrm{O}_{2}$ (PPO) and $238 \mathrm{PuO}_{2}$

Percent of Body Burden

Dog Number

PPO

$\begin{array}{lll}\frac{P P O}{1032 M} & \frac{921 \mathrm{~F}}{27} & \frac{931 \mathrm{~F}}{28}\end{array}$

\begin{tabular}{ccc} 
PMC & \\
\hline$\frac{940 M}{8}$ & $\frac{950 M}{28}$ & $\frac{948 \mathrm{~F}}{28}$
\end{tabular}

Lungs

96.9

92.8

96.0

94.

$90.1 \quad 97.5$

Thoracic Lymph Nodes ${ }^{b}$

$\begin{array}{lll}0.3 & 0.7 & 1.9\end{array}$

$\begin{array}{lll}0.3 & 0.9 & 0.7\end{array}$

Liver

$1.7 \quad 0.4$

0.1

$0.7 \quad 0.7$

0.3

Skeleton

$0.2 \quad 2.1$

0.3

2.4

2.1

0.9

Muscle

$0.4 \quad 2.4$

0.3

$\begin{array}{lll}1.2 & 1.8 & 0.4\end{array}$

Skin

$\begin{array}{lll}0.1 & 0.3 & 1.3\end{array}$

$\begin{array}{lll}0.8 & 3.1 & 0.1\end{array}$

A11 Remaining Tissues

$0.4 \quad 1.3$

0.1

$\begin{array}{lll}0.5 & 1.3 & 0.1\end{array}$

Final Body Burden ( $\mathrm{nC} i$ )

$\begin{array}{lll}149.5 & 4.4 & 347.1\end{array}$

19.6

$9.0 \quad 80.4$

a. Several of these low-level tissue samples are being recounted using longer counting times to evaluate $\mathrm{Pu}$ content in liver, skeleton, muscle, skin and other low-1evel tissues.

b. Tracheobronchial, mediastinal and sternal lymph nodes.

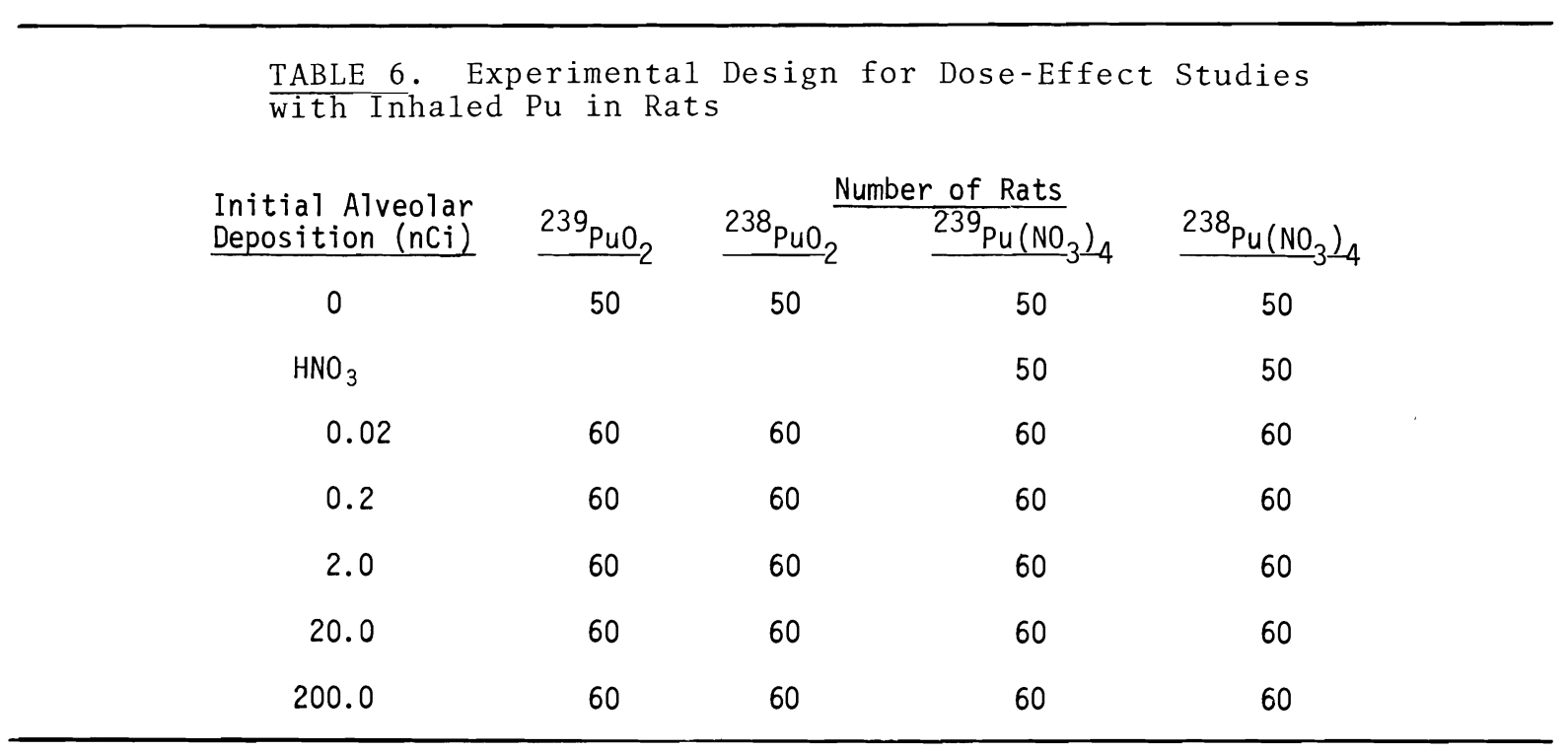




\title{
CARCINOGENICITY OF INHALED PLUTONIUM-238 FROM CRUSHED MICROSPHERES
}

\author{
Investigator: \\ C. L. Sanders \\ Technical Assistance: \\ Doris M. Meier and G. J. Powers
}

\begin{abstract}
Following inhalation of "soluble" $238 \mathrm{Pu}, 12$ to $25 \%$ of the initial alveolar lung burden remained in the body 1 to $2 \mathrm{yr}$ after exposure; 0.3 to $1 \%$ of this was in the lungs and $50 \%$ in the skeleton. The lung tumor incidence was 6.6, 23.3, and $25 \%$ for initial lung deposition of 5, 18, and $230 \mathrm{nCi}$, and average radiation doses of 9,32 , and 375 rads, respectively. There was a $1.1 \%$ incidence of lung tumors in controls. The incidence of all tumors other than mammary tumors was $4.3 \%$ in the unexposed controls and in the 238 Pu-exposed rats, $26.7,36.6$, and $46.8 \%$.
\end{abstract}

The design and preliminary results of this experiment were described in some detail in last year's Annual Report.

Three groups of 70-day-old female rats were exposed to an aerosol of "soluble" $238 \mathrm{Pu}$ (u1trafilterability $72 \%$, CMD 0.02, GSD 2.1) derived from crushed ${ }^{238} \mathrm{PuO}_{2}$ microspheres suspended in physiological saline for 2 to 3 months prior to the animal exposures. Mean initial lung depositions were $5 \mathrm{nCi}$ (Group I), $18 \mathrm{nCi}$ (Group II) and $230 \mathrm{nCi}$ (Group III).

Alpha tracks on autoradiograms of lung at one day after exposure, were randomly distributed throughout the alveolar tissues, most $1 \mathrm{y}$ as single tracks. Other than small peribronchial aggregates with hemosiderin, 1ittle evidence of ${ }^{238} \mathrm{Pu}$ was seen in the lung after a year postexposure. on 1 y $1 \%$ of initial1y deposited $238 \mathrm{Pu}$ remained in the lung after $1 \mathrm{yr}$; and on 1 y $0.3 \%$ after 600 days (Figure 1 ). Total retention was $25 \%$ of inhaled dose after $1 \mathrm{yr}$, decreasing to $12 \%$ at 1000 days; about $50 \%$ of this was in the skeleton. The mean accumulated radiation doses to the lung after 2 yr were about 9,32 , and $375 \mathrm{rads}$ for the three groups; corresponding doses to skeletal tissues were 2,20 , and 150 rads.

Control animals exhibited a median 1 ife-span of 825 days; the median 1 ife-spans for those exposed to ${ }^{238} \mathrm{Pu}$ ranged from 675 days down to 550 days for the highest exposure level (Figure 2). The incidence of lung tumors was $1.1 \%(1 / 92)$ for controls, $6.6 \%$ $(2 / 30)$ for Group I, 23.3\% (7/30) for Group II and $25 \%(8 / 32)$ for Group III (Table 1). The tumors were primarily peripheral bronchiolar adenocarcinomas and squamous ce11 carcinomas; several exhibited metastatic growth (Table 2).

of the 34 extra-mammary tumors found in rats exposed to ${ }^{238} \mathrm{Pu}, 50 \%$ were found in lung and $50 \%$ in other organs or tissues, including skeleton, ovary, kidney, urinary bladder, uterus, skin, intestine, adrenal, 


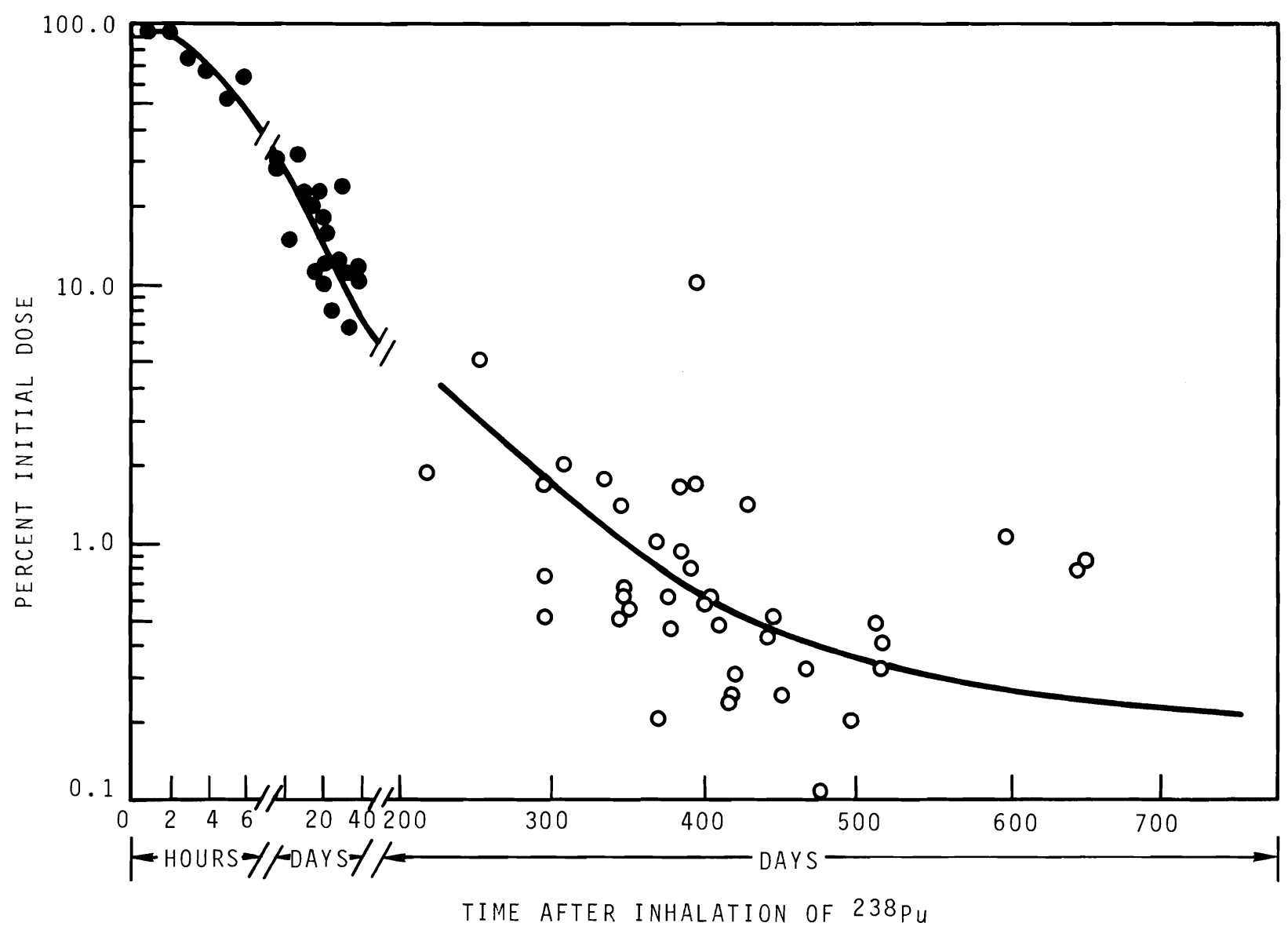

FIGURE 1. Retention of ${ }^{238} \mathrm{Pu}$ in the Lung. Data for the first 40 days after deposition were obtained from another experiment in which the same type of $238 \mathrm{Pu}$ was administered by intratracheal instillation.

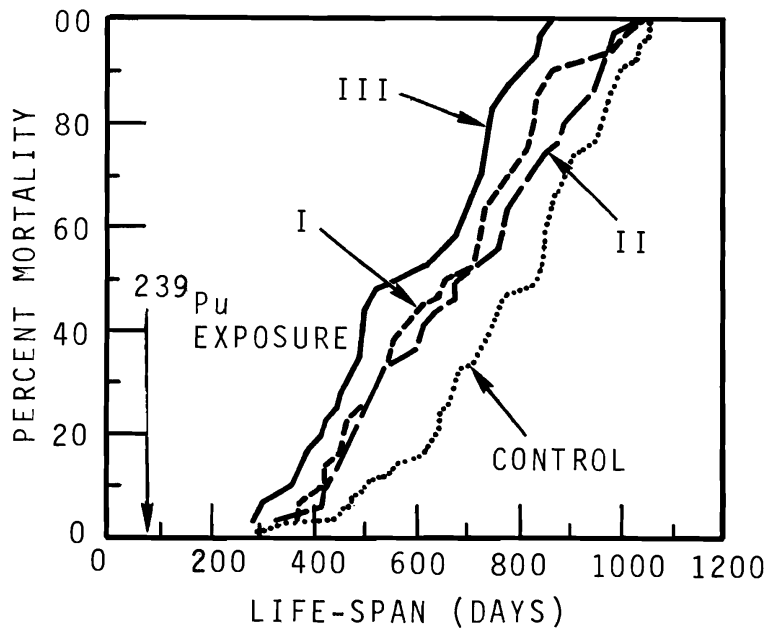

FIGURE 2. Cumulative Mortality of Control and $238 \mathrm{Pu}-$ Exposed Rats pancreas, spleen and abdominal lymph node. Three animals developed osteogenic sarcomas at bone doses of 51 , 96 and 152 rads, respectively. Control animals developed myelogenous leukemia (2/91), undifferentiated carcinoma in lung (1/91) and carcinoma of the kidney $(1 / 91)$. Tumors found in exposed animals were predominant1y carcinomas (Table 2). The incidence of nonmammary tumors in $238 \mathrm{Pu}$-exposed rats was $26.7 \%$ for Group I, 36.6\% for Group II and $46.8 \%$ for Group III, as compared to a $4.3 \%$ 
TABLE 1. Incidence of Tumors in the Lung and Other Tissues of the Rat, Excluding Mammary Tumors, as a Function of $238 \mathrm{Pu}$ Exposure. The level of significant difference of exposed rats from controls was determined by chi-square test.

\begin{tabular}{|c|c|c|c|}
\hline \multirow[b]{2}{*}{ Group } & \multirow[b]{2}{*}{$\begin{array}{l}\text { Number of } \\
\text { Animals }\end{array}$} & \multicolumn{2}{|c|}{ Incidence of Tumors } \\
\hline & & Lung & $\begin{array}{c}\text { A11 } \\
\text { Nonmammary } \\
\text { Tumors } \\
\end{array}$ \\
\hline Control & 92 & 1.1 & 4.3 \\
\hline I & 30 & 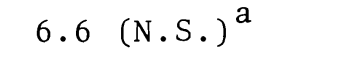 & $26.7(\mathrm{p}<0.0001)$ \\
\hline I I & 30 & $23.3(\mathrm{p}<0.0001)$ & $36.6(\mathrm{p}<0.00001)$ \\
\hline I I I & 32 & $25.0(\mathrm{p}<0.0001)$ & $46.8(\mathrm{p}<0.00001)$ \\
\hline
\end{tabular}

TABLE 2. Tumor Type, Location and Incidence as a Function of ${ }^{238} \mathrm{Pu}$ Exposure

Tumor

Mammary Fibroadenoma
Mammary Adenocarcinoma
Pulmonary Tumors
Bronchiolo-alveolar Adenocarcinoma
Epidermoid Carcinoma
$\quad$ Mixed Carcinomas
Undifferentiated Carcinoma
$\quad$ Lymphosarcoma
Uterine Carcinomas
Uterine Leiomyosarcoma
Ovarian Carcinoma
Bladder Transitional Ce11 Carcinoma
Adrena1 Pheochromocytoma
Renal Transitional Ce11 Carcinoma
Cutaneous Squamous Ce11 Carcinoma
Intestinal Adenocarcinoma
Pancreatic Carcinoma
Abdominal Reticulum Ce11 Sarcoma
Splenic Lymphosarcoma
Osteogenic Sarcoma
Myelogenous Leukemia

\begin{tabular}{|c|c|c|c|}
\hline \multirow{2}{*}{ Control } & \multicolumn{3}{|c|}{ Incidence of Tumors $(\%)$} \\
\hline & Group I & Group I I & Group III \\
\hline 57.6 & 53.3 & 50.0 & 43.7 \\
\hline 14.1 & 20.0 & 10.0 & 18.8 \\
\hline- & 6.6 & 13.3 & 21.9 \\
\hline- & - & - & 3.1 \\
\hline-- & -- & 6.6 & - \\
\hline 1.1 & - & -- & -- \\
\hline- & - & 3.3 & - \\
\hline-- & 6.6 & 3.3 & 3.1 \\
\hline-- & -- & 3.3 & -- \\
\hline-- & - & - & 3.1 \\
\hline-- & -- & -- & 3.1 \\
\hline-- & 3.3 & -- & -- \\
\hline 1.1 & 3.3 & - & -- \\
\hline- & - & 3.3 & - \\
\hline- & - & 3.3 & -- \\
\hline- & 3.3 & - & -- \\
\hline-- & 3.3 & - & -- \\
\hline-- & -- & -- & 3.1 \\
\hline-- & -- & -- & 9.4 \\
\hline 2.2 & -- & - - & -- \\
\hline
\end{tabular}


incidence in unexposed control animals (Figure 3, Table 2). The incidence of mammary tumors in unexposed rats was not different from that found in ${ }^{238} \mathrm{Pu}$-exposed rats (Table 2).

Exposure of rats to a "soluble" $238 \mathrm{Pu}$ aerosol resulted in a significant incidence of tumors in the lung and in other tissues at radiation doses that have not previously been shown to be carcinogenic in animals. It was further concluded that spread ing the $\mathrm{Pu}$ dose in the lung, as compared to concentrating in $\mathrm{PuO}_{2}$ particles, is more carcinogenic due to the greater number of epithelial ce11s "hit" by alpha emissions from $\mathrm{Pu}$.

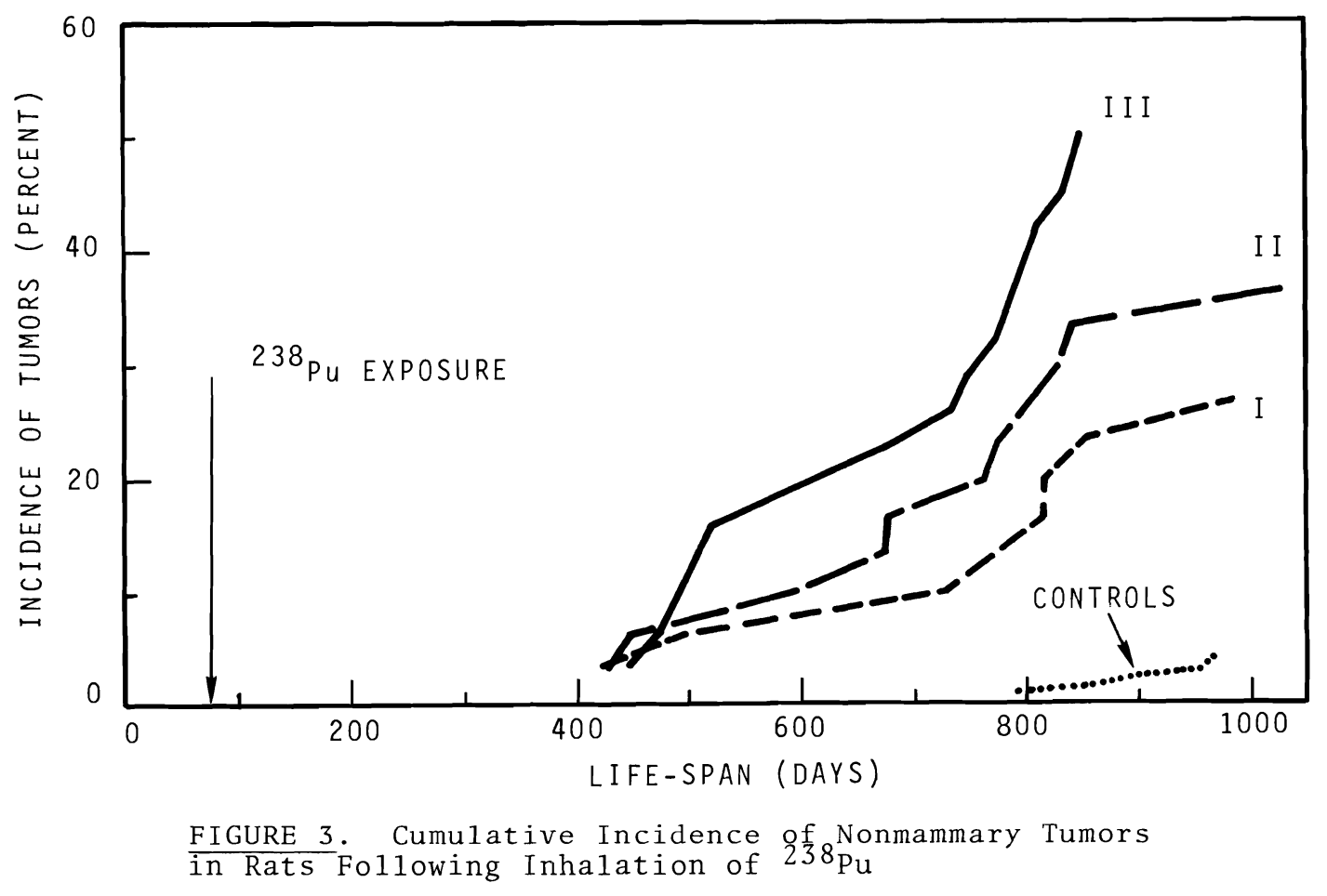




\section{THE LONG-TERM BIOLOGICAL EFFECTS OF INTRATRACHEALLY INSTILLED ${ }^{25{ }^{3} \mathrm{ESCl}_{3} \text { IN RATS }}$}

Investigator:

J. E. BalZou and W. G. Morrow

The biological effects of ${ }^{253}$ Es are of interest for comparison with $\mathrm{Pu}$ because of the relatively short half-1ife of ${ }^{253}$ Es (20.5 days) and the resulting differences in temporal and spatial distribution of the radiation dose. Male rats were administered $0.5 \mathrm{ml}$ of ${ }^{253} \mathrm{EsCl}_{3}$ in $\mathrm{HCl}$ solution ( $\mathrm{pH} 2$ ), according to the dose levels shown in Table 1. Retention curves in Figure 1 were determined from rats administered $2.2 \mu \mathrm{Ci}$ ${ }^{253} \mathrm{EsCl}_{3}$. The intratracheal mode of administration was employed because only a smal1 amount of ${ }^{253}$ Es was available and an accurate measure of the administered dose was required. The long-term animals are weighed each month and observed daily for survival and gross or histopathologic lesions. The radiation dose to lung, kidney, liver and skeleton was calculated using parameters determined. from the short-term retention curves (Figure 1).

The 1ong-term effects of intratracheal ${ }^{253} \mathrm{EsCl}_{3}$ were characterized by: (1) a depressed rate of growth which was dose related, shown in Figure 2; (2) early death due to radiation pneumonitis in the 47.2 $\mu \mathrm{Ci} / \mathrm{kg}$ group; (3) death due to neoplastic lesions in bone and soft tissues, and leukemia in the $10.7 \mathrm{\mu Ci} / \mathrm{kg}$ group; and (4) essentially no effect at the lowest level of $0.214 \mu \mathrm{Ci} / \mathrm{kg}$. The study is still in progress and histopathologic examination of tissues is not yet complete to establish the incidence of tumors or tumor type.

TABLE 1. Biologic Effect of Intratracheally

Instilled $253 \mathrm{EsCl} 3$ in Rats (Observations to

607 Days Postadministration)

\begin{tabular}{|c|c|c|c|c|c|}
\hline \multirow{2}{*}{$\begin{array}{c}\text { Administered } \\
\text { Dose } \\
(\mu \mathrm{Ci} / \mathrm{kg}) \\
\end{array}$} & \multicolumn{4}{|c|}{$\begin{array}{l}\text { Estimated Cumulative } \\
\text { Radiation Dose (rads) }\end{array}$} & \multirow[b]{2}{*}{ Survival } \\
\hline & Lung & Kidney & Liver & Skeleton & \\
\hline 47.2 & 15,000 & 1,000 & 250 & 3,000 & $0 / 29$ \\
\hline 10.7 & 3,000 & 200 & 50 & 600 & $11 / 48$ \\
\hline 0.214 & 60 & 5 & 1 & 15 & $31 / 48$ \\
\hline $\mathrm{HCl} \mathrm{pH} 2$ & -- & -- & -- & -- & $33 / 43$ \\
\hline
\end{tabular}




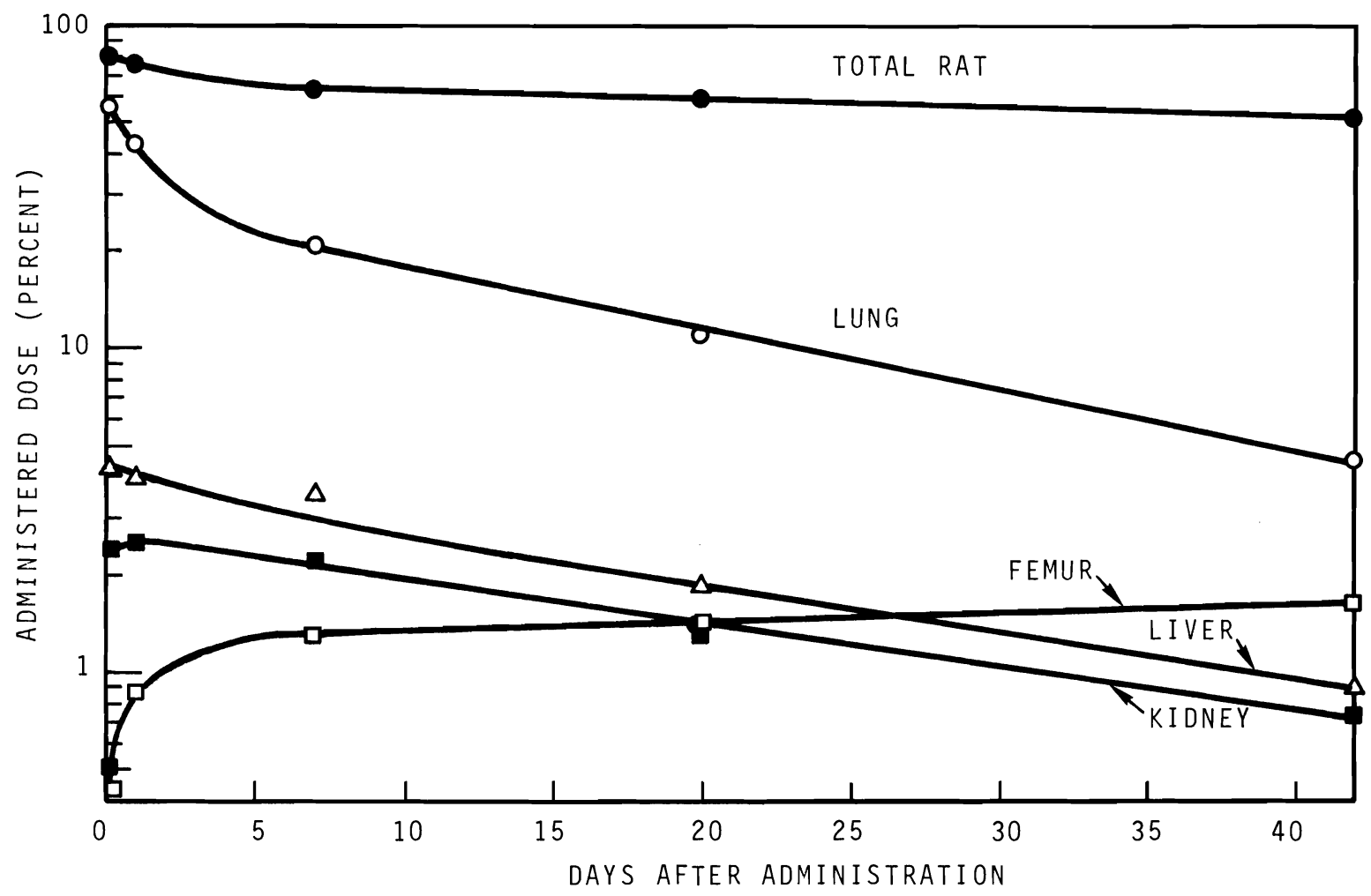

FIGURE 1. Retention of ${ }^{253}$ Es in Rat Tissues Following Intratracheal Instillation of $253 \mathrm{EsCl}_{3}$

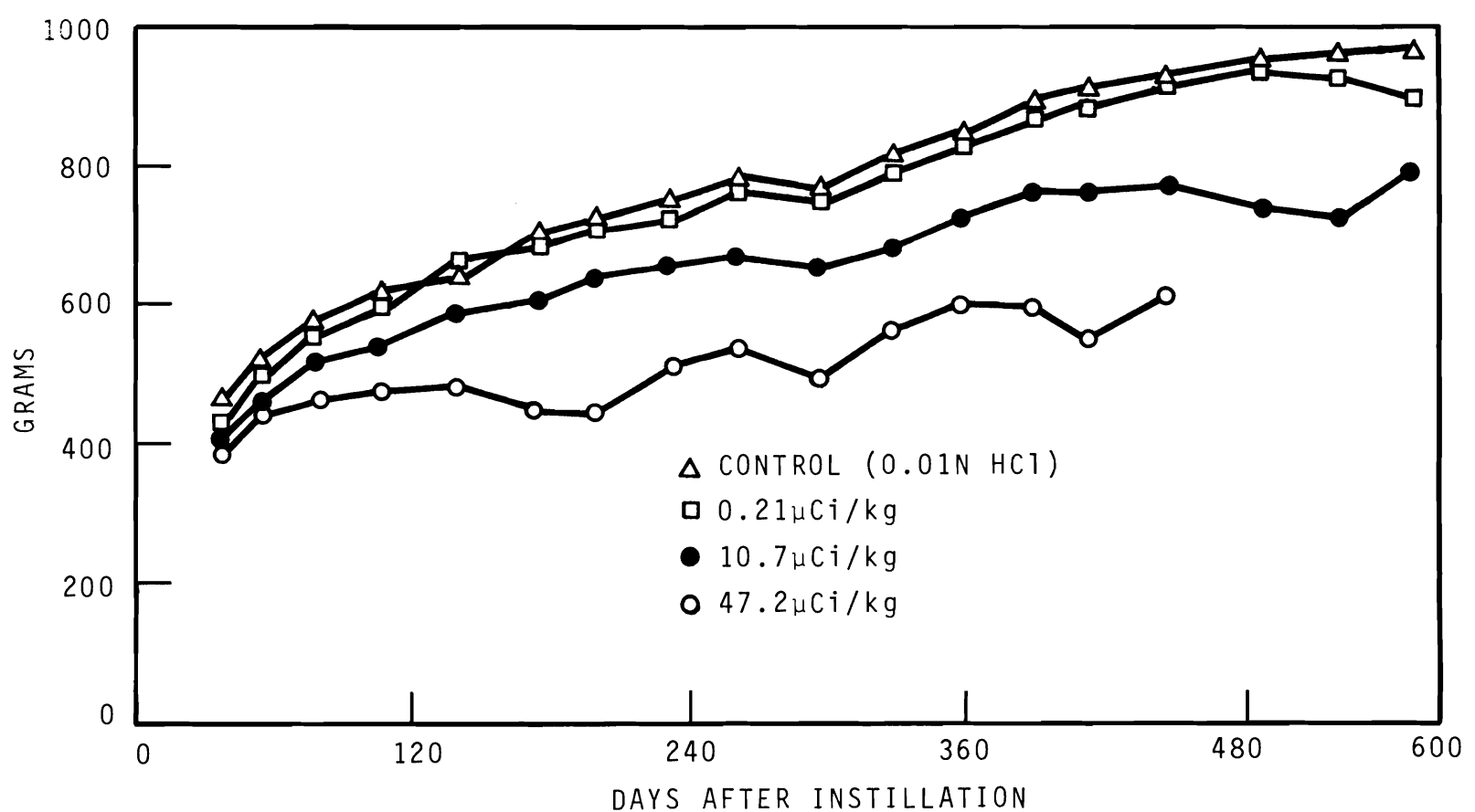

FIGURE 2. Effect of Intratracheally Instilled ${ }^{253} \mathrm{EsCl}_{3}$ on Rat Weight 


\section{COCARCINOGENIC EFFECT OF ${ }^{239} \mathrm{Pu} 02$ AND ASBESTOS IN THE LUNG}

Investigator:

C. L. Sanders

Technical Assistance:

Doris M. Meier

Previous studies in rats demonstrated the additive action of ${ }^{239} \mathrm{PuO}_{2}$ particles and chrysotile asbestos, deposited in the abdominal cavity, on the induction of abdominal sarcomas and mesotheliomas. The combination of both carcinogens produced as many or more of these tumors than was obtained by adding tumor incidences from the agents given singly (Annual Report, 1971). An experiment was initiated to investigate possibly similar effects in the lung.

Four groups of rats were given intratracheal instillations of either (1) ${ }^{239} \mathrm{PuO}_{2}$, (2) chrysotile asbestos,

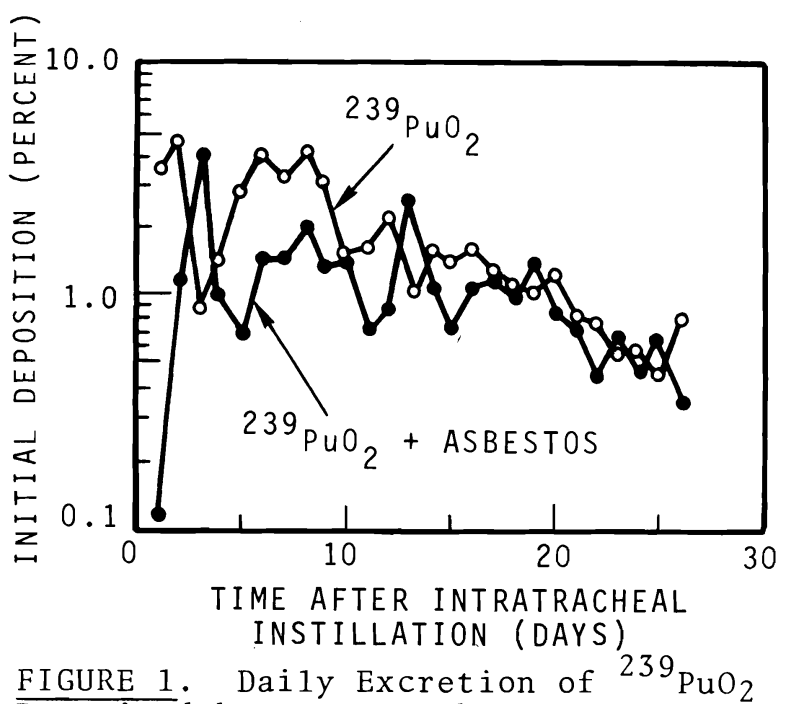
Deposited by Intratracheal Instillation, as Influenced by Co-Administration of Chrysotile Asbestos. Over $98 \%$ of the $239 \mathrm{Pu}$ excreted was present in feces. Initial $239 \mathrm{PuO}_{2}$ deposition was about $50 \mathrm{nCi}$; initial asbestos deposition was $1 \mathrm{mg}$. Values are means of 3 rats in each group.
(3) ${ }^{239} \mathrm{PuO}_{2}+$ chrysotile asbestos, or (4) saline. Particulates were suspended in $0.3 \mathrm{~m} 1$ saline prior to instillation. The co-administration of ${ }^{239} \mathrm{PuO}_{2}$ with asbestos resulted in less excretion of ${ }^{239} \mathrm{Pu}$ than was the case with ${ }^{239} \mathrm{PuO}_{2}$ only (Figure 1).

Focal granulomatous lesions were common around bronchiolar areas of the lung in animals receiving asbestos. Plutonium oxide particles tended to concentrate in these asbestos-induced lesions forming "hot spots" of alpha activity (Figure 2). Data on further pathologic effects are not yet available.

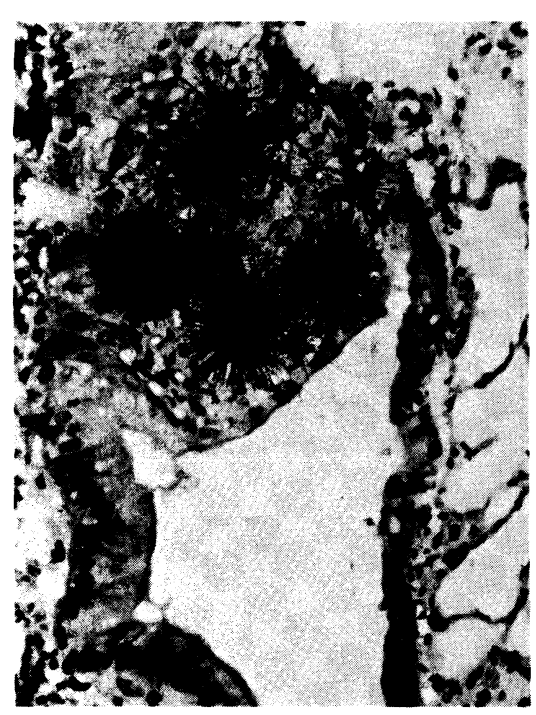

FIGURE 2. Localization of ${ }^{239} \mathrm{PuO}_{2}$ Particles in Asbestos-Induced Lesion in Rat Peribronchiolar Area at 30 Days After Intratracheal Instillation of $239 \mathrm{PuO}_{2}+$ Chrysotile Asbestos. 


\title{
BILIARY EXCRETION OF INJECTED ${ }^{238} \mathrm{PU}$
}

\author{
Investigators: \\ C. Astiey and C. L. Sanders
}

Biliary excretion is an important mechanism for clearance of liver $\mathrm{Pu}$. The experimental manipulations used to study biliary excretion may influence the tissue distribution and excretion of $\mathrm{Pu}$ by other routes. Groups of five rats were subjected to several manipulations required for bile duct cannulation and bile collection. Cannulated animals received $0.45 \% \mathrm{NaC} 1$ in their drinking water to replace lost electrolytes. Restraining animals in cylindrical wire cages significantly reduced the urinary and fecal excretion of injected ${ }^{238} \mathrm{Pu}$. Nembutal anesthesia prevented the reduced urinary ${ }^{238} \mathrm{Pu}$ excretion caused by restraining in wire cages, but had no effect on fecal excretion of ${ }^{238} \mathrm{Pu}$. On $1 \mathrm{y} 2.4 \%$ of injected $238 \mathrm{Pu}$ was found in the bile collected continuously for 5 days after $\mathrm{Pu}$ injection (Table 1). Bile flow rates were twice as high when bile was collected for only $1 \mathrm{hr} / \mathrm{day}$ and diverted

TABLE 1. Tissue Distribution and Excretion of Intraperitoneally Injected 238Pu. Urine and feces were collected for 5 days, at which time the animals were killed for tissue analysis. Values are means \pm standard deviation.

\begin{tabular}{|c|c|c|c|c|c|c|c|c|c|c|c|c|}
\hline \multirow{3}{*}{$\begin{array}{c}238 \mathrm{Pu} \\
\begin{array}{c}\text { Distribution } \\
\text { in Tissues }\end{array} \\
\text { Bone }\end{array}$} & \multicolumn{5}{|r|}{ Percent } & \multicolumn{5}{|c|}{${ }^{238} \mathrm{Pu}$ in Groups ${ }^{\mathrm{a}}$} & \multirow{2}{*}{\multicolumn{2}{|c|}{ E }} \\
\hline & & A & & & $\mathrm{B}$ & & $\bar{C}$ & & & $\mathrm{D}$ & & \\
\hline & 54 & \pm & 3.6 & 45 & \pm 9.3 & 45 & \pm & 1.5 & 44 & \pm 5.0 & 45 & \pm 2.3 \\
\hline Liver & 0.34 & \pm & 0.21 & 15 & \pm 11 & 16 & \pm & 1.8 & 15 & \pm 1.1 & 17 & \pm 1.4 \\
\hline Spleen & 0.59 & \pm & 0.25 & 0.37 & \pm 0.09 & 0.33 & \pm & 0.05 & 0.21 & \pm 0.05 & 0.30 & \pm 0.04 \\
\hline Lung & 1.9 & \pm & 0.12 & 0.21 & \pm 0.07 & 0.20 & \pm & 0.02 & 0.19 & \pm 0.05 & 0.18 & \pm 0.08 \\
\hline Skin & 0.70 & \pm & 0.75 & 2.4 & \pm 1.1 & 2.0 & \pm & 0.78 & 4.2 & \pm 1.5 & 2.2 & \pm 1.5 \\
\hline G.I. Tract & 0.94 & \pm & 0.83 & 2.0 & \pm 0.92 & 2.7 & \pm & 0.65 & 1.6 & \pm 0.73 & 3.2 & \pm 1.5 \\
\hline Thorax & 1.6 & \pm & 0.92 & 0.50 & \pm 0.15 & 0.19 & \pm & 0.03 & 0.26 & \pm 0.10 & 0.10 & \pm 0.02 \\
\hline Kidney & 0.47 & \pm & 0.42 & 2.5 & \pm 0.28 & 1.9 & \pm & 0.51 & 2.4 & \pm 0.29 & 1.8 & \pm 0.52 \\
\hline Total in Body & 81 & \pm & 7.2 & 84 & \pm 5.0 & 83 & \pm & 4.2 & 92 & \pm 1.9 & 81 & \pm 3.6 \\
\hline Tota1 in Urine & 13 & \pm & 4.8 & 12 & \pm 3.4 & 12 & \pm & 3.3 & 5.1 & \pm 1.8 & 9.8 & \pm 2.7 \\
\hline Total in Bile & 2.4 & \pm & 1.4 & & - & & - & & & - & & - \\
\hline Total in Feces & 3.3 & \pm & 1.7 & 3.6 & \pm 2.0 & 4.2 & \pm & 1.6 & 3.0 & \pm 0.69 & 9.0 & \pm 3.8 \\
\hline
\end{tabular}

a. Nembutal, bile duct cannulation, animal restrained (A); nembutal, sham surgery, animal restrained (B); nembutal, animal restrained (C); animal restrained (D); none (E). 
back into the G.I. tract the remaining $23 \mathrm{hr} / \mathrm{day}$, as compared to bile flow rates when the bile was collected continuously during a 5-day period after cannulation. Cannulation of the bile duct prior to injection of ${ }^{238} \mathrm{Pu}$ greatly reduced the amount of $238 \mathrm{Pu}$ in liver, while increasing the amount of ${ }^{238} \mathrm{Pu}$ present in bone. About $0.3 \%$ of ${ }^{238} \mathrm{Pu}$ given to rats by gavage along with bile and $\mathrm{NaOH}$ to neutralize stomach $\mathrm{HCl}$, was retained in the body at 10 days after administration.

These limited studies suggest that the experimental manipulations re- quired to study ${ }^{238} \mathrm{Pu}$ excretion in bile may greatly modify the normal response of the animal so as to make interpretation difficult. It seems preferable to collect bile for only a few hours per day and to divert the bile back into the G.I. tract during the remaining time. Bile duct cannulation should be carried out several days prior to injection of ${ }^{238} \mathrm{Pu}$. Less than half the ${ }^{238} \mathrm{Pu}$ excreted in feces was accounted for in the bile, indicating $10 \mathrm{ss}$ of ${ }^{238} \mathrm{Pu}$ in feces via diffusion or secretion from gut mucosa. 


\title{
DETECTION OF CYTOTOXIC LYMPHOCYTES IN BEAGLES WITH ${ }^{238}$ PU-INDUCED BONE TUMORS
}

Investigator:

\author{
M. E. Frazier
}

Technical Assistance:

T. K. Andrews

Ce11 cultures were prepared from eight dogs that had inhaled Pu. These dogs showed no sign of lung tumors, but did have areas of apparent pulmonary fibrosis. The cells cultured from these dogs displayed none of the characteristics of ${ }^{239} \mathrm{Pu}$-induced lung tumor ce11s. Un1ike cultured ${ }^{239} \mathrm{Pu}$ induced lung tumor cells, these cells were difficult to maintain in culture, possessed predominately fibroblastic characteristics and did not divide in soft agar. The greater ease of growth of lung tumor cells as compared to these lung cells may be due to the loss of normal contact inhibition mechanisms in the cultured lung tumor cells.

Bone tumor cells from a beagle that had been exposed to ${ }^{238}$ Pu by inhalation were injected intraperitoneally into neonatal puppies. This experiment was designed to investigate the transmissibility of ${ }^{238} \mathrm{Pu}$-induced canine bone tumors. These animals at 9 months of age showed no evidence of tumors, but they were producing lymphocytes that were cytotoxic to cultured ${ }^{238} \mathrm{Pu}$-induced canine bone tumor cells (Figure 1).

Preliminary experiments suggest that cell lines prepared from canine bone tumors (a11 bone tumors referred to throughout this paper are ${ }^{238} \mathrm{Pu}$ induced canine bone tumors) have at

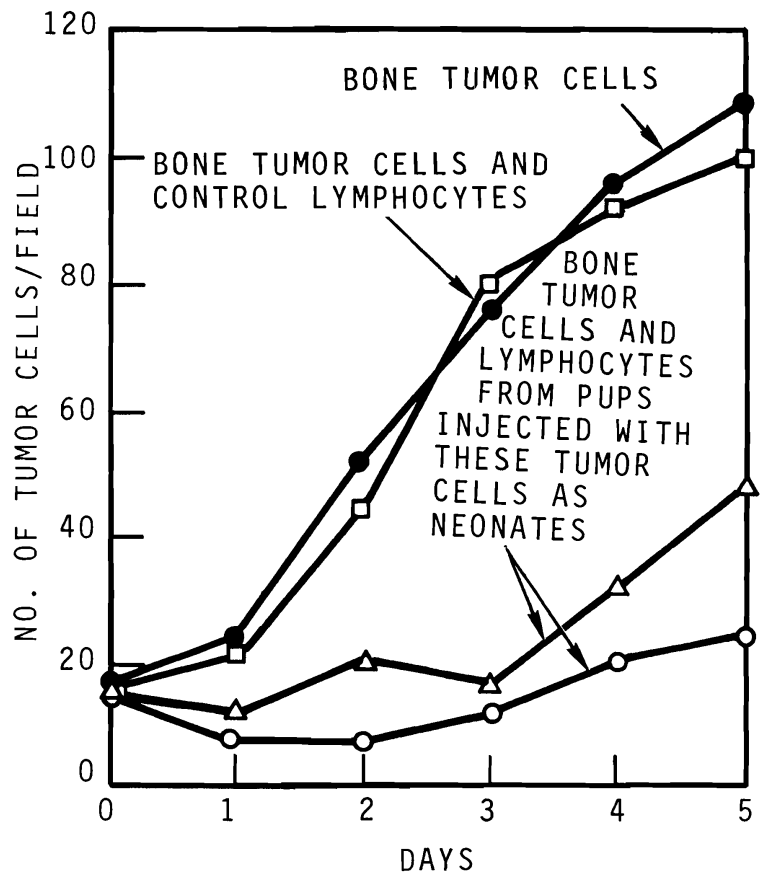

FIGURE 1. Effects of Lymphocytes on the Growth of Bone Tumor Cells in Vitro

least one antigen which is common to bone tumors found in other dogs that inhaled ${ }^{238} \mathrm{Pu}$. Dogs with these bone tumors a1so possess 1ymphocytes that are cytotoxic to cultured bone tumor cells from heterologous animals (Figure 2). Cultured cells from a spontaneous mammary tumor and ${ }^{239} \mathrm{Pu}-$ induced canine lung tumor cells were not killed by these lymphocytes, implying a degree of specificity based on tumor type. In addition, a specific serum-blocking factor, capable 


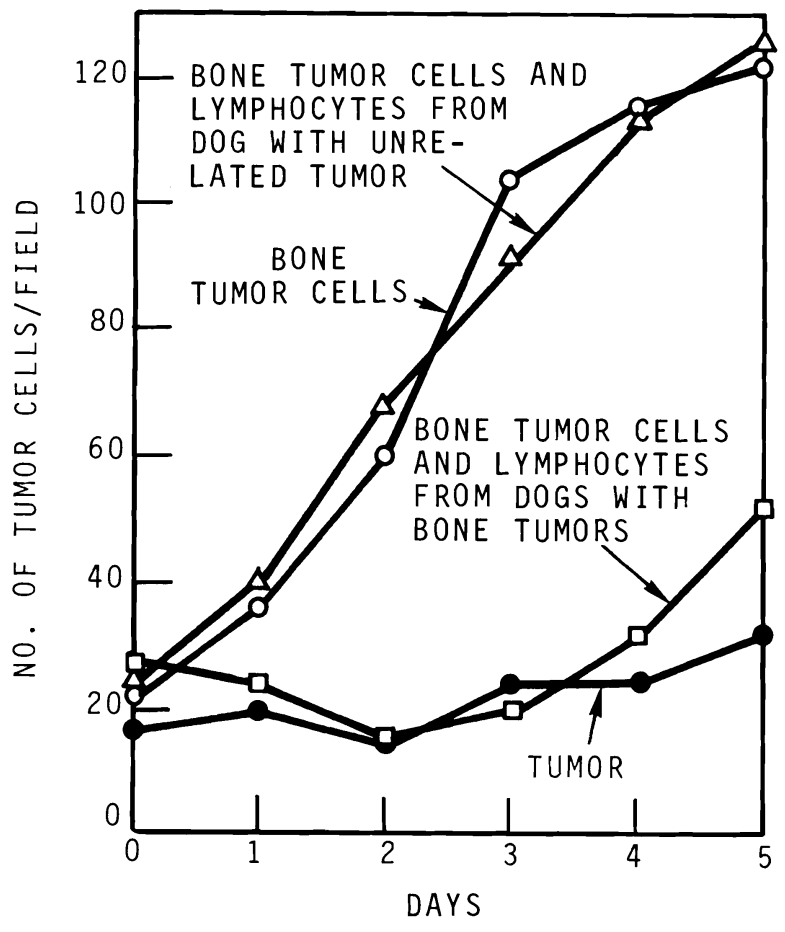

FIGURE 2. Effect of Lymphocytes from Two Dogs with $238 \mathrm{Pu}$-Induced Bone Tumors on Cultured Bone Tumor Cells from Another Dog. The cytotoxic action of these lymphocytes suggests that a common tumor antigen may be present in a11 $238 \mathrm{Pu}$-induced canine bone tumors.

of preventing the cytotoxic effect of 1 ymphocytes directed against canine bone tumor cells, has been found in one dog dying from such a bone tumor (Figure 3).
Tumors, cultured tumor cells, and lymph nodes from several dogs exposed to $\mathrm{Pu}$ have been prepared for electron microscopic examination, and they will be examined for virus particles.

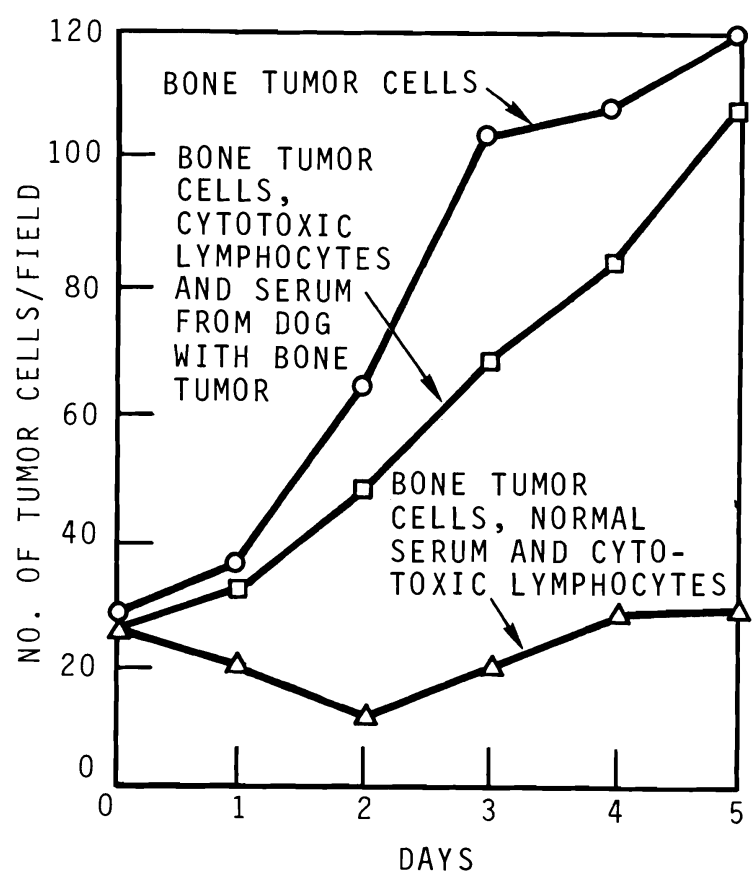

FIGURE 3. A Factor in the Serum of a Dog with a Bone Tumor Protects Cultured Bone Tumor Cells from the Cytotoxic Action of Lymphocytes 


\title{
DIRECT DETERMINATION OF THE PERCENTAGE TOTAL DEPOSITION OF AEROSOLS INHALED BY BEAGLE DOGS
}

\author{
Investigators: \\ D. K. Craig, J. R. Decker, and J. P. Herring \\ Technical Assistance: \\ E. F. Blanton, R. D. Carmichael, D. L. Catt, \\ G. L. Webb, and E. L. Wierman
}

A two-way valving system designed to separate expired from inspired air has been built as an integral part of the venturi used to measure a dog's respiration parameters during aerosol inhalation exposures. The exhaled air is collected in a 30 liter meteorologic balloon, from which a cascade impactor sample can be drawn while the dog is being exposed. Figure 1 shows the complete valving system, including the fiberglass mask into which the dog fits (upper right) and a filter holder through which air from the balloon may be exhausted after completion of the exposure (upper left). Three female beagles have each been exposed three times to ${ }^{198} \mathrm{Au}-1$ abelled gold aerosols (half-1ife, 2.7 days) using this system. Filter paper and cascade impactor samples were used to analyze the inhaled and exhaled aerosol. Total activity in the balloon air was added to activity deposited in the balloon and the exhaust plumbing to obtain the total exhaled activity. Activity retained in the dogs was assessed in a thorax counter 2,8 , and 15 to 16 days postexposure. All excreta were collected and analyzed for this period, enabling estimates to be made of both total initial deposition (activity retained + activity excreted) and probable alveolar deposition of inhaled $\mathrm{Au}$.

Results for the final series of exposures, expressed as a percentage of the measured inhaled activity (total initial deposition + total exhaled activity), are presented in Table 1. A calculated inhaled activity value close to $100 \%$ indicates a good balance of materials between the inhaled and exhaled aerosols. The system gives satisfactory results, though some leakage of air past the dog mask for \#1029 caused her inhaled activity to be underestimated.

Both inhaled and exhaled aerosols were 1 og-normally distributed. It is interesting that there is no significant difference between the AMADs obtained for the inspired and the expired aerosol. However, the GSDs increased to between 1.93 and 1.98 (from 1.65 and 1.71). This meant that the CMD of the aerosols decreased from the range 0.13 to 0.14 $\mu \mathrm{m}$ in the inspired aerosol to 0.09 to $0.10 \mu \mathrm{m}$ in the expired aerosol.

The utility of this system for separating expired from inspired air during inhalation exposures has been demonstrated. The additional information yielded, namely the total initial deposition of inhaled material, 


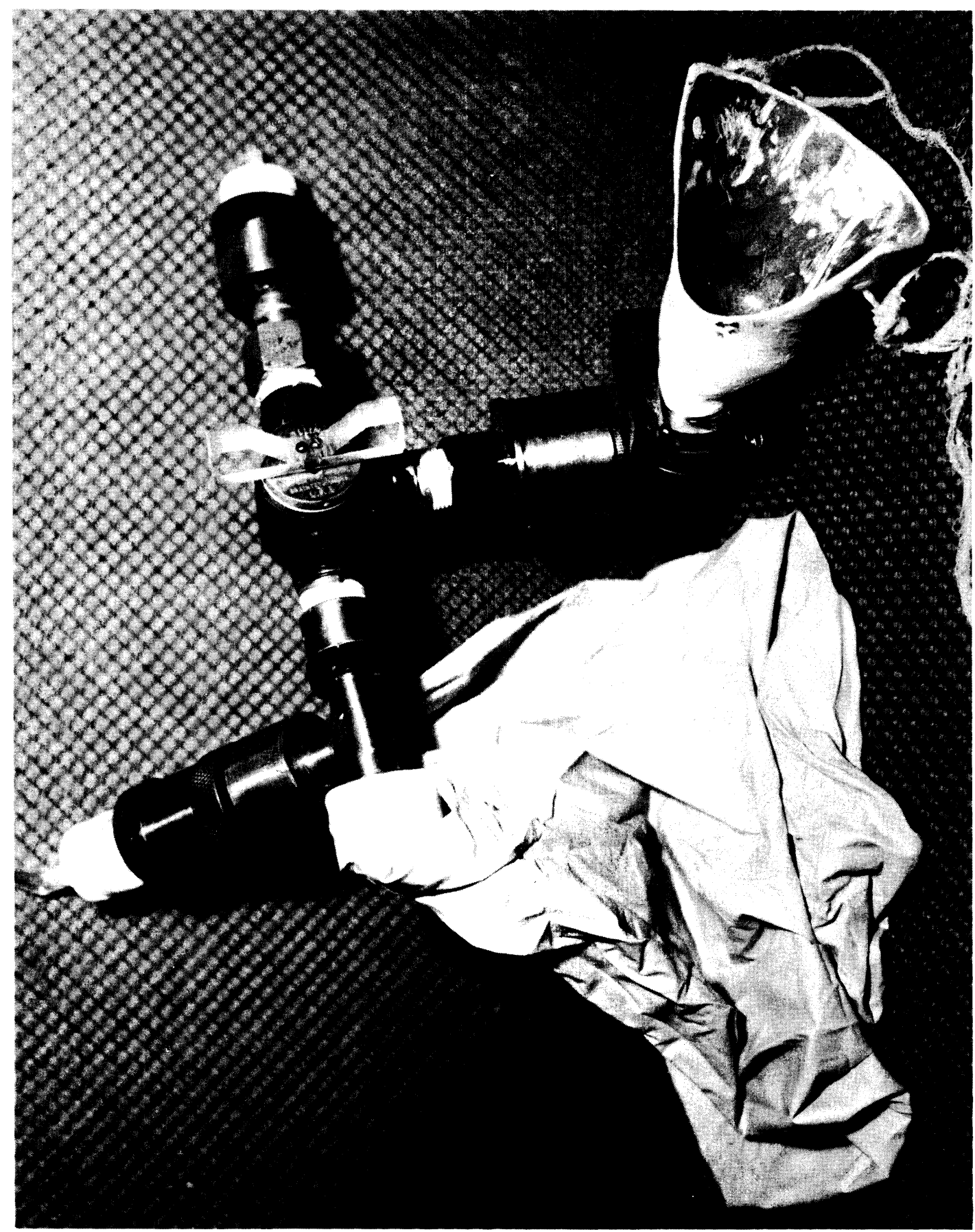

FIGURE 1. Valving System for Separating Expired from Inspired Air in Dog During Inhalation Exposures, Including Fiberglass Mask (Upper Right), Filter Holder (Upper Left), Balloon (Lower Right) and Cascade Impactor (Left). 
TABLE 1. Direct Determination of Total Initial Deposition of Inhaled 198Au-Labeled Gold Aerosols in Beagle Dogs by Separation of Expired from Inspired Air

Values at 2 Days Postexposure Are Expressed as a Percentage of Measured Inhaled Activity

\begin{tabular}{|c|c|c|c|}
\hline & $\begin{array}{l}\text { Dog } \\
\text { Number } \\
928 \mathrm{~F} \\
\end{array}$ & $\begin{array}{l}\text { Dog } \\
\text { Number } \\
980 \mathrm{~F} \\
\end{array}$ & $\begin{array}{l}\text { Dog } \\
\text { Number } \\
1029 \mathrm{~F} \\
\end{array}$ \\
\hline $\begin{array}{l}\text { Calculated } \\
\text { Inhaled Activity } \\
\text { (conc. x vol. } \\
\text { inhaled) }\end{array}$ & 96.3 & 91.3 & 73.3 \\
\hline $\begin{array}{l}\text { Activity Retained } \\
\text { (thorax count } \\
\text { postexposure) }\end{array}$ & 11.4 & 30.0 & 12.1 \\
\hline $\begin{array}{l}\text { Activity Excreted } \\
\text { (feces + urine up } \\
\text { to thorax count) }\end{array}$ & 54.3 & 37.6 & 51.5 \\
\hline $\begin{array}{l}\text { Total Initial } \\
\text { Deposition } \\
(2+3)\end{array}$ & 65.7 & 67.7 & 63.6 \\
\hline $\begin{array}{l}\text { Activity Exhaled } \\
\text { During Exposure }\end{array}$ & 34.3 & 32.3 & 36.4 \\
\hline $\begin{array}{l}\text { Measured } \\
\text { Inhaled Activity } \\
\text { in nCi }\end{array}$ & 3736 & 3006 & 2952 \\
\hline $\begin{array}{l}\text { AMAD Inhaled } \\
(\mu \mathrm{m}) \text { Exhaled }\end{array}$ & $\begin{array}{l}1.540 \\
1.647\end{array}$ & $\begin{array}{l}1.677 \\
1.657\end{array}$ & $\begin{array}{l}1.699 \\
1.708\end{array}$ \\
\hline $\begin{array}{l}\text { GSD Inhaled } \\
\text { Exhaled }\end{array}$ & $\begin{array}{l}1.747 \\
1.978\end{array}$ & $\begin{array}{l}1.785 \\
1.931\end{array}$ & $\begin{array}{l}1.756 \\
1.934\end{array}$ \\
\hline $\begin{array}{l}\text { CMD Inhaled } \\
(\mu \mathrm{m}) \text { Exhaled }\end{array}$ & $\begin{array}{l}0.130 \\
0.088\end{array}$ & $\begin{array}{l}0.133 \\
0.098\end{array}$ & $\begin{array}{l}0.142 \\
0.100\end{array}$ \\
\hline
\end{tabular}

the activity exhaled and the relative size distributions of the inhaled and exhaled aerosols, is considerable and the system can be recommended for incorporation in our other dog inhalation exposure chambers. 


\section{INHALATION HAZARDS TO URANIUM MINERS}

Uranium miners are exposed to many potentially carcinogenic air contaminants (including $\mathrm{Rn}$, Rn daughters, $\mathrm{U}$ ore dust, diesel engine exhaust, and cigarette smoke) that could account for the sixfold increased incidence of lung cancer among $U$ miners of the Colorado plateau. In addition to the separate or combined biologic effects of these agents, their concommitant presence causes important physical interaction; the high concentrations of condensation nuclei in operating $U$ mines result in less than $3 \%$ unattached Rn daughters causing a distribution of radiation dose in the respiratory tract different from that which may occur in other environments. Neither the Working Level concept of total potential alpha disintegration nor the ICRP value based upon Rn concentrations and unattached RaA adequately deals with differing absorbed dose patterns.

The objectives of this project are to determine cause and effect relationships of inhaled $U$ mine air pollutants in experimental animals for comparison with similar observations in $U$ miners and to determine the mechanisms of action of these agents or combinations of agents in the development of lung pathology. An understanding of these relationships will aid in determining if reduction of Rn daughter exposure alone is sufficient to reduce the risk of lung cancer in $U$ miners or if reduced exposure to other potential carcinogens should also be considered.

\section{PUBLICATIONS}

STUART, B. O., R. H. BUSCH, and

R. F. PALMER. Studies of the Effects of Inhaled Radon Daughters, Uranium Ore Dust, and Diesel Engine Exhaust in Hamsters. Health Phys., vol. 23, p. 417. (Abstract). 1972.
STUART, B. O., D. H. WILLARD, and E. B. HOWARD. Studies of Inhaled Radon Daughters, Uranium ore Dust, and Cigarette Smoke in Dogs and Hamsters. In: Inhaled Particles III, p. 543, Unwin Bros. Lt'd., Gresham Press, England. 1972. 


\title{
EFFECTS IN HAMSTERS OF LIFE-SPAN INHALATION EXPOSURE TO SIMULATED URANIUM MINE ATMOSPHERES
}

\author{
Investigators: \\ B. O. Stuart and R. H. Busch \\ Technical Assistnace: \\ H. G. Steele, J. C. Gaven, and E. J. Rossignol
}

\begin{abstract}
Hamsters are receiving life-time daily 6-hr inhalation exposures to various combinations of Rn daughters, U ore dust, and diesel engine exhaust at levels causing no effects on mortality, body weights, or hematology. Histopathologic examination of tissues has shown the greatest variety of severe pathologic effects in hamsters exposed to 1200 WL Rn daughters with U ore plus diesel exhaust. Invasive squamous cell carcinoma was obsered in hamsters receiving 1200 WL Rn daughters with and without uranium ore dust.
\end{abstract}

Life-span studies with hamsters are designed to determine the roles and effective levels of the principal mine air contaminants in causing lung pathology. The initial hamster studies (Phase I) have been completed, in which hamsters inhaled $30 \mathrm{WL}$ Rn daughters, $600 \mathrm{WL}, 600 \mathrm{WL}$ with $\mathrm{U}$ ore dust $\left(15 \mathrm{mg} / \mathrm{m}^{3}\right.$ ), or laboratory air (controls). In phase II of these experiments, 6 groups of 102 male hamsters each have received 1 ife-span expo- sures according to the protocol in Table 1 .

Methods for generating and monitoring the various exposure atmospheres were described in previous reports. Particle size spectra of U ore aerosols indicate a count median diameter ranging from 0.19 to $0.36 \mu \mathrm{m}$.

The presence of submicron particles in $U$ ore and/or diesel exhaust aerosols greatly increases the levels of condensation nuclei to which $\mathrm{Rn}$

TABLE 1. Phase II Life-Span Exposures of Six Groups of 102 Hamsters Each

\begin{tabular}{clc} 
Group & \multicolumn{1}{c}{ Exposure } & Funded by \\
\cline { 2 - 2 } 1 & Controls (1aboratory air) & AEC \\
2 & 1200 WL Rn daughters & AEC \\
3 & 1200 WL Rn daughters with & \\
& U ore dust $\left(15 \mathrm{mg} / \mathrm{m}^{3}\right)$ & AEC \\
4 & U ore dust $\left(15 \mathrm{mg} / \mathrm{m}^{3}\right)$ & AEC \\
5 & Diese1 engine exhaust, $50 \mathrm{ppm} \mathrm{CO}$ & HEW \\
6 & Diese1 engine exhaust (50 ppm CO) p1us & \\
& $1200 \mathrm{WL}$ Rn daughters with U ore dust & HEW \\
& $\left(15 \mathrm{mg} / \mathrm{m}^{3}\right)$
\end{tabular}


daughters principally attach and may in this way affect deposition patterns and subsequent biologic response. Daily measurements of condensation nuclei levels in each chamber show counts for the Group 1 (contro1) and Group 2 (1200 WL) chambers ranging from 2000 to 8600 per $\mathrm{cm}^{3}$; Group 3 (1200 WL + U ore dust), 60,000 to 173,000 per $\mathrm{cm}^{3}$; Group 4 (U ore dust), 51,000 to 120,000 per $\mathrm{cm}^{3}$; Group 5 (diesel exhaust), 110,000 to 235,000 per $\mathrm{cm}^{3}$; and Group $6(1200 \mathrm{WL}$ + ore dust + diesel exhaust), 155,000 to 340,000 per $\mathrm{cm}^{3}$. Periodic determinations of percent unattached daughters, using the modified Mercer cascade impactor, show $0.5 \%$ unattached Rn daughters in the chamber also containing the U ore aerosol (Group 3), 1ess than $0.3 \%$ in the presence of diesel exhaust condensation nuclei (Group 5), but 15 to $30 \%$ or more unattached RaA in the $1200 \mathrm{WL}$ chamber containing Rn daughters only (Group 2). Periodic sacrifices of additional test hamsters followed by rapid gamma spectrographic analyses are being made to determine absorbed doses from individual Rn daughters and to study their subsequent biologic disposition as influenced by these three widely different free ion (unattached Rn daughter) fractions.

A11 of the original 612 hamsters of the Phase II studies are now dead. There were no significant differences in mean body weight or mortality patterns between exposed and control groups throughout the exposure period. Bimonthly hematologic sampling of selected hamsters in each group showed no significant differences in peripheral blood cell levels compared to controls. The original Phase II hamsters were sacrificed for histopathologic examination when moribund. In order to observe the pathogenesis of these changes, to obtain tissues from animals without complications of morbidity, to determine tissue burdens of short-lived Rn daughters for dose determination, and to obtain exfoliative cells by lung lavage for correlation with developing pathology, 54 hamsters were added to each group, including the control group, and are being sacrificed in groups of nine at $1,2,4,6,8$, and 10 months of exposure.

Tissues from the original Phase II hamsters have been examined histologica11y; they represent subjects exposed for times ranging from 2 to 20 months. After 6 months of exposures, enteritis developed in 15 to $20 \%$ of hamsters in a11 groups including controls. The situation persisted for approximately $3 \mathrm{wk}$, then subsided to a very low leve1. A few hamsters surviving past 1 yr exposure in a 11 groups, including controls, developed generalized amyloidosis involving kidneys, adrenals, spleen, 1 iver and occasionally other organs. Other disease conditions are of low incidence, including interstitial pneumonitis and chronic glomerulonephritis. Nonpulmonary neoplasms were present at low incidence in all groups as follows: Group 1 - one hemangioendothelioma, two reticulum ce11 sarcomas, one myelogenous leukemia; Group 2 - one reticulum cell sarcoma, one undifferentiated sarcoma; Group 3 - two osteosarcomas, one 
undifferentiated carcinoma, one myelogenous leukemia; Group 4 - one reticulum cell sarcoma, one hemangioendothelioma, one melanoma; Group 5 one undifferentiated carcinoma, one reticulum cell sarcoma; and Group 6 two reticulum ce11 sarcomas. Osteosarcoma is rare in hamsters, and its occurrence in hamsters of Group 3 receiving 1200 WL Rn daughters plus U ore containing long-1ived alpha emitters, including $230 \mathrm{Th}$ and $226 \mathrm{Ra}$, is of interest.

Control hamsters show generally lesion-free lungs during the first year of exposures to laboratory air only. The hamsters of Group 6 (diesel exhaust, Rn daughters, U ore dust) have shown the greatest variety and most extensive pulmonary patho1ogy throughout the experimental period; other groups developed similar lesions at slower rates. After a few months of exposures, emphysema was observed, and there was an accumulation of particulate material in macrophages localized around small vessels and bronchioles. With time, emphysema became more severe and particle depositions progressively denser and more diffuse throughout the lungs. Alveolar septal cell hyperplasia occurred after a few weeks of exposures. Increased numbers of inflammatory cel1s, neutrophils, lymphocytes and plasma cell types became more abundant within septa. After more than a year of exposures to ore dust, vast fields of macrophage and fibroblast populations gave the appearance of more classic pneumoconiosis - evidently silicosis due to the silica present in U ore. Epi- thelial lesions other than septal cell hyperplasia also occurred, consisting of morphological changes representing stages of progression. Early, basal cells of the bronchial and bronchiolar epithelium began to appear hyperplastic and crowded. Goblet cells increased in size and number. With time, atypical and degenerate epithelial cells appeared, and squamous metaplasia began to appear after about 1 yr of exposure in Group 3 and Group 6 hamsters (Figure 1). Proliferating cuboidal epithelium, described as bronchiolization, cuboidal metaplasia, adenomatoid proliferation or adenomatosis, began to appear coincident with basal cell hyperplasia.

In the second year of exposure, proliferating cuboidal epithelium appeared to be lining alveoli and was frequently found in large areas of

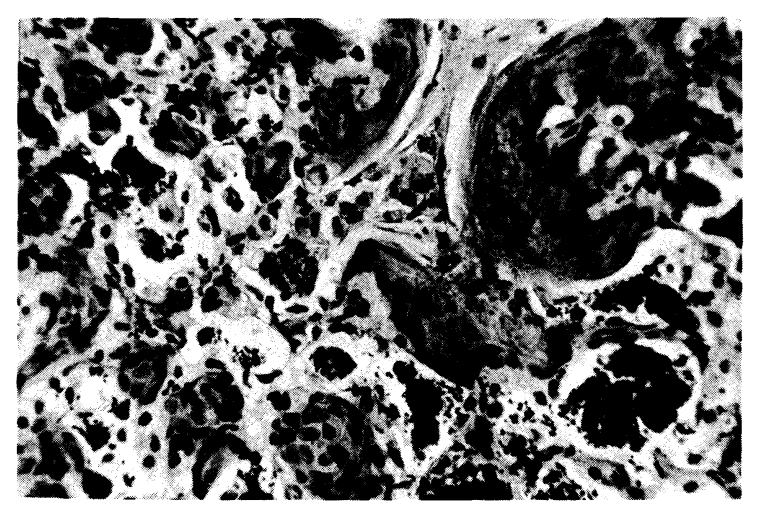

HEE $260 X$

FIGURE 1. Lung Section from a Hamster After 17 Months of Daily Exposures to 1200 WL Rn Daughters with U Ore Dust Plus Diesel Engine Exhaust. The section shows squamous metaplasia with atypia and degenerating metaplastic cells. 
the lungs, continuous with more normal alveolar lining. This epithelium was frequently ciliated and has been observed in all experimental groups except Group 5 (diesel exhaust only). Group 5 animals often show such proliferation adjacent to and continuous with bronchiolar epithelium. In a few animals of Groups 2, 3, 4, and 6 , sacrificed after 15 to 17 months of exposure, a morphologically different epithelial lesion was present. This lesion was small, well circumscribed and peripherally located, with cells appearing columnar and with piled cells becoming horizontally flattened and developing into squamous metaplasia. No cilia were seen on cells in these lesions, which were found only in lungs with exten-

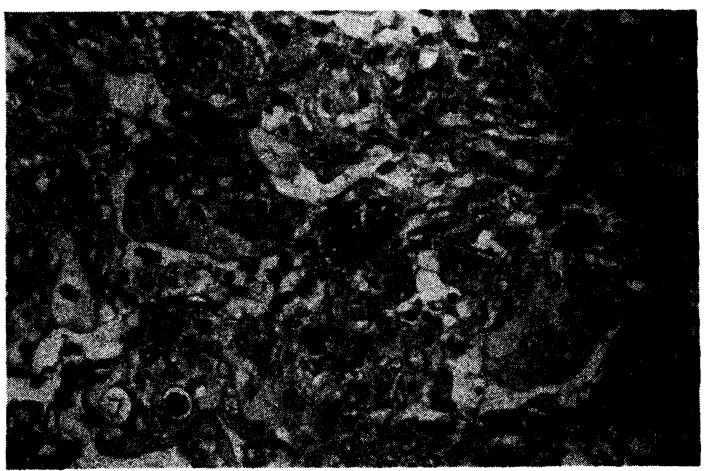

H\&E 260X

FIGURE 2. Lung Section from a Hamster After 16 Months of Daily Exposures to 1200 WL Rn Daughters. The section shows a squamous tumor in the periphery of the lung that has obscured normal lung structure. sive pathology. Individual cells in these lesions showed considerable variation in size, nuclear-cytoplasm ratio and nuclear outlines and were often irregular with chromatin margination. In hamsters of Groups 2 and 3 , the metaplastic squamous epithelium showed each stage of progression from "typical squamous metaplasia" through all stages of "atypical squamous metaplasia" and finally features of carcinoma in two of the Group 2 and one of the Group 3 hamsters (Figures 2, 3, and 4). The exact point of transformation to unequivocal invasive squamous cell carcinoma cannot be ascertained; however, the fact that the three animals showing these lesions also show all

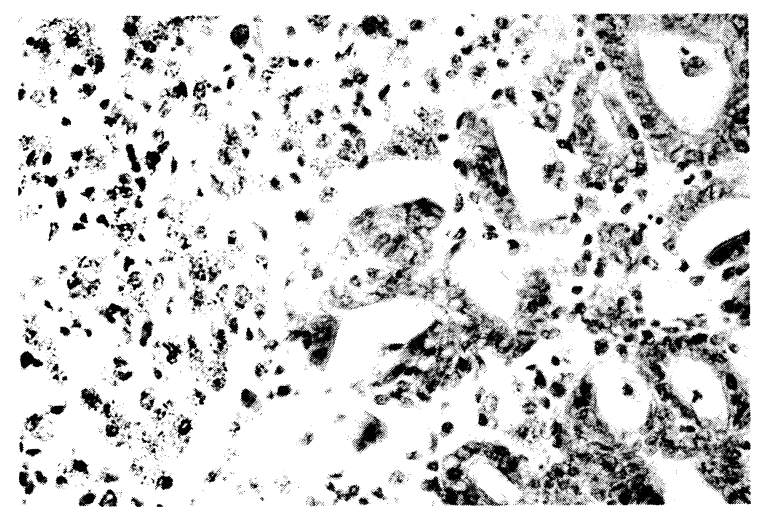

HE्E 260X

FIGURE 3. Lung Section from a Hamster After 15 Months of Daily Exposures to $1200 \mathrm{WL}$ Rn Daughters with $15 \mathrm{mg} / \mathrm{m}^{3} \mathrm{U}$ Ore Dust. The sections have accumulations of particulate-bearing macrophages adjacent to areas of squamousappearing cells beginning to show atypia. 


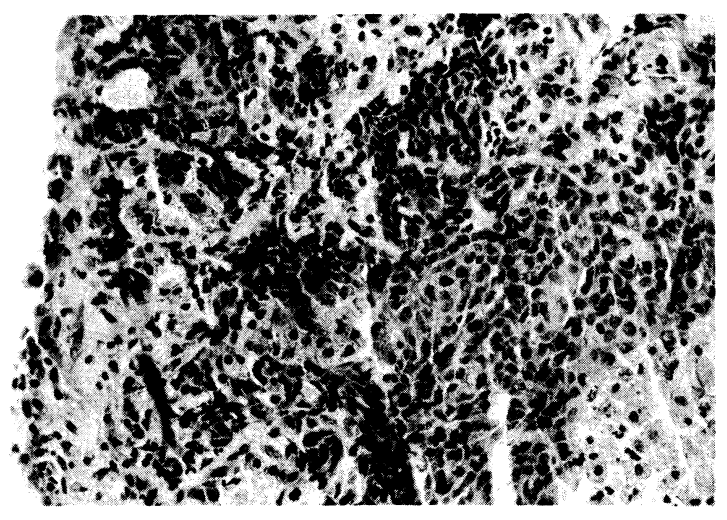

HEE $163 \mathrm{X}$

FIGURE 4. Lung Section from a Hamster After 16 Months of Daily Exposures to $1200 \mathrm{WL} R \mathrm{R}$ Daughters with $15 \mathrm{mg} / \mathrm{m}^{3} \mathrm{U}$ Ore Dust. The slide shows a squamous carcinoma in the periphery of the lung . stages of progression from simple basal cell hyperplasia in bronchioles to malignant tumor strongly suggest at least precancerous status for much of the epithelial change. This development of pulmonary neoplasia in hamsters during 1 ife-span daily exposures to $1200 \mathrm{WL}$ Rn daughters with and without $U$ ore dust is highly significant because the species has an essentially zero incidence of spontaneous pulmonary neoplasia and because the Syrian golden hamster is widely accepted as a model for human respiratory pathology.

\title{
EFFECTS IN BEAGLE DOGS OF LIFE-SPAN INHALATION EXPOSURE TO SIMULATED URANIUM MINE ATMOSPHERES
}

\section{Investigators:}

B. O. Stuart, R. H. Busch, H. A. Ragan, and $P$. L. Hackett

Technical Assistance:

J. C. Gaven, W. Skinner, K. C. Upton,

E. J. Rossignol, G. M. Lewis, L. R. Peters,

W. A. Zimmerman, and $N$. Perez

\begin{abstract}
Sixty beagles have now received 39 months of daily inhalation exposures to various combinations of $R$ n daughters, $U$ ore dust, and cigarette smoking. Higher than control neutrophil and total leukocyte levels in the group exposed to all three insults are the only gross effects noted to date. Histologic changes are seen in the lungs at autopsy. Retention of $230 \mathrm{Th}$ was greater than that of $234 U$ in all tissues.
\end{abstract}

In 1 ife-span studies, 20 beagles are continuing to receive daily exposures to $600 \mathrm{WL}$ of Rn daughters with $15 \mathrm{mg} / \mathrm{m}^{3} \mathrm{U}$ ore dust and with sham cigarette smoking; 20 dogs (supported by HEW) receive the same exposure and in addition smoke 10 cigarettes per day over a $16-\mathrm{hr}$ period; and 20 dogs (supported by HEW) receive cigarette 
smoking only. Two Rn daughterexposure chambers, a11owing head-on1y exposures, provide daily 4 -hr exposures for 40 dogs. Condensation nuclei counts are taken twice daily in each chamber and in room air; chamber counts range from 65,000 to 110,000 per $\mathrm{cm}^{3}$; 1aboratory air counts range from 2000 to 9500 per $\mathrm{cm}^{3}$. Routine physical examinations, periodic thoracic radiographs, hematology and clinical chemistry are obtained for each dog. After nearly 3 yr of exposure, no consistent changes in respiratory rates, minute volumes, tidal volumes or clinical chemistry, including blood urea nitrogen, glucose and alkaline phosphatase, have occurred; creatinine levels were slightly higher in dogs exposed to 600 WL Rn daughters with ore.

Two dogs receiving daily exposures to cigarette smoke plus Rn daughters with $U$ ore showed indistinct, diffuse densities in current radiographs. Total white blood cell counts and absolute segmented neutrophil levels remain significantly higher $(\mathrm{p}<0.05)$ for the last two periods in the group receiving $\mathrm{Rn}$ daughters with ore plus cigarette smoke; the changes apparent in the exfoliative cytology of these dogs indicate that the neutrophilia may be a response to chronic irritation and increased pulmonary cell death rate. All other white blood ce11 levels, including lymphocytes, eosinophils, monocytes, and banded neutrophils, remain not significant $1 y$ different from controls.
The lungs of a dog that died after 31 months of exposure to $600 \mathrm{WL} \mathrm{Rn}$ daughters with $U$ ore showed diffuse and focal deposition of $U$ ore particles throughout a11 lobes. Particulate material contained in macrophages had exudated into alveoli or had congregated around small vessels and bronchioles. Septal cell proliferation was apparent in a11 areas of the lung. The epithelium of bronchi and bronchioles showed considerable hyperplasia. Goblet cells were increased in size and number. Chronic inflammatory changes were present, involving peribronchial and peribronchiolar areas as well as bronchial glands. In the more severely involved areas septal fibrosis was present in adjacent alveoli (Figure 1). Nearly all lobes showed focal or patchy areas in which proteinaceousappearing structures were present in alveoli. In some areas these structures involved hyperplasia of alveolar epithelium. Macrophages appeared adjacent to some deposits, and in other areas frank granulomatous reactions were present. Many foreign body giant cells could be seen in the granulomatous foci (Figure 2). Often these cells contained material similar to the amorphous deposits in their cytoplasm. Similar structures have been observed in human subjects exposed to certain dusts and fumes.

Samples of lung lobes, tracheobronchial and mediastinal lymph nodes, and systemic organs, including kidneys and liver, were radiochemically analyzed for long-lived alpha emitters present in the carnotite $U$ ore 


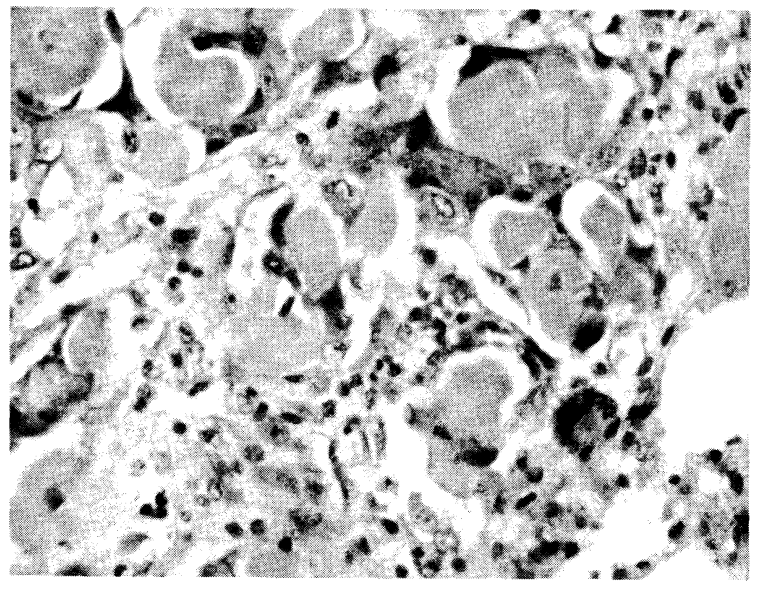

HEE $320 X$

FIGURE 1. Lung Section from a Beagle Exposed for 31 Months to 600 WL Rn Daughters with U Ore. Proteinaceousappearing structures have filled alveoli. Alveolar septa appear thickened with chronic inflammatory cells, and macrophages have exudated into alveolar sacs.

in secular equilibrium that is inhaled daily. These tissues were obtained from two dogs that were sacrificed after 6 months of daily inhalation of $600 \mathrm{WL}$ Rn daughters with $15 \mathrm{mg} / \mathrm{m}^{3}$ carnotite $U$ ore and the same concentrations of $\mathrm{Rn}$ daughters with ore plus daily cigarette smoking. Marked nonequilibrium ratios (different from 1.0) of $230_{\mathrm{Th}} /{ }^{234} \mathrm{U}$ were observed in all tissues, ranging from 4.2 to 6.8 in lungs, 2.9 to 23 in mediastinal and tracheobronchial

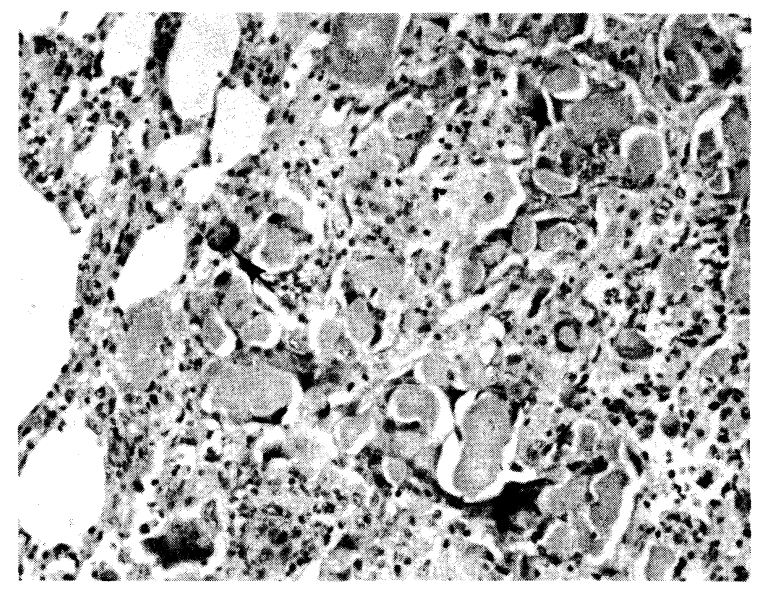

HEE $205 \mathrm{X}$

FIGURE 2. Lung Section from a Beagle Exposed for 31 Months to $600 \mathrm{WL}$ Rn Daughters with U Ore. Granulomatous reaction to proteinaceous bodies. Foreign body giant cells (arrow) are present.

lymph nodes, 1.4 to 2.1 in kidneys, and approximately 8 in liver. This higher retention of ${ }^{230} \mathrm{Th}$ than ${ }^{234} \mathrm{U}$ in a11 tissues, especially lungs and thoracic lymph nodes, corroborates previous findings of consistently higher Th levels in dogs exposed to a high-grade pitchblende $U$ ore alone. These findings emphasize the need for re-evaluation of the maximum permissible concentrations established for airborne U ore, currently based only on $\mathrm{U}$ content. 


\title{
COMPARATIVE EFFECTS IN HAMSTERS, RATS, AND MICE OF EXPOSURE \\ TO SIMULATED URANIUM MINE ATMOSPHERES
}

\section{Investigators:}

R. F. Palmer and B. O. Stuart

Technical Assistance:

H. G. Steele and J. C. Gaven

\begin{abstract}
Hamsters, SPF rats, and mice are being chronically exposed to 3000 to $6000 \mathrm{WL}$ of radon daughters with and without uranium ore dust to provide interspecies comparison of the effects of these uranium mine inhalation hazards.
\end{abstract}

Phase I studies with hamsters at 30 WL Rn daughters (representing the highest levels in some areas of working $\mathrm{U}$ mines) produced slight pulmonary response, but 1 ife-span daily exposures to $600 \mathrm{WL}$ Rn daughters with U ore dust caused vesicular emphysema, fibrosis, metaplasia, and adenomatous lesions with anaplasia. In experiments involving 1200 WL Rn daughters, diesel engine exhaust and $U$ ore dust, described above as Phase II studies, pulmonary lesions have become more severe with accelerated development of epithelial metaplasia and the appearance of squamous tumors. Studies at the University of Rochester have shown a threefold reduction in 1 ifespan in mice exposed to $1750 \mathrm{WL}$ Rn daughters (150 hr/wk) but no increase above spontaneous control incidence of adenomatous tumors. Investigators in France have reported peripheral tumors in the lungs of SPF rats after $500 \mathrm{hr}$ of exposure to $\sim 1 \mu \mathrm{Ci} / \ell$ of $\mathrm{Rn}$, but neither $\mathrm{Rn}$ daughter concentrations nor attachment fractions were measured, and no correlation to human exposure histories based on Rn daughter Working Levels is possible.
In order to correlate these results and to provide direct interspecies comparison of the biologic effects of exposures to characterized aerosols of $U$ mine air contaminants, experiments were initiated with SPF rats, hamsters and mice. These rodents are exposed 90 hr/wk to atmospheres containing Rn daughter levels ranging from 3000 to $6000 \mathrm{WL}$, with or without $18 \mathrm{mg} / \mathrm{m}^{3} \mathrm{U}$ ore dust. Radon daughters and $U$ ore dust are generated and monitored in the manner presently employed in our continuing $U$ mine atmosphere studies. The three species are exposed simultaneously in the same chambers with 16 animals of each species exposed to each of the two atmospheres. Animals are sacrificed when moribund, and tissues retained for histopathologic examination. At 4 months of exposures, mortality is nearly complete; rodents inhaling $\mathrm{Rn}$ daughters alone received $6.2 \times 10^{6}$ workinglevel-hours total exposure, and rodents inhaling $\mathrm{Rn}$ daughters with U ore dust received $7.0 \times 10^{6}$ workinglevel-hours. Histopathlogy on sacrificed animals is in progress. 


\title{
CHARACTERIZATION OF ACTUAL AND SIMULATED
} URANIUM MINE ATMOSPHERES

\section{Investigators:}

J. A. Cooper, * P. O. Jackson, *

J. C. Langford, * and M. R. Petersen*

\begin{abstract}
Radioactivity versus particle size studies in exposure chambers containing $R$ n daughters with $U$ ore dust and/or diesel engine exhaust show activity peaks for all Rn daughters at vo.1 $\mu \mathrm{m}$. The chamber receiving Rn daughters alone contained up to 30\% unattached RaA with high diffusion rates. X-ray fluorescence analyses show $T i, V, F e, C u, Z n, P b$ and $U$ at levels ranging from $0.06 \%$ to $2.5 \%$ in airborne $U$ ore in chambers and mines. High molecular weight polycyclic hydrocarbons correlate closely with soot loading at different size levels.
\end{abstract}

The organic, elemental and radioactive constituents of the simulated $\mathrm{U}$ mine atmospheres in animal test chambers were studied as a function of particle size using Lundgren, Andersen and low pressure impactors. The soot from the diesel exhaust chambers peaked on the fifth stage $(0.2 \mu \mathrm{m})$ of the six-stage low pressure impactor. Unburnt diesel fuel appeared in greatest concentration on the first stage and decreased down the stages until it was absent on the backup filter. A gross mixture of high molecular weight hydrocarbons was separated from the diesel exhaust components in the chromatograms and correlated well with the visible soot load. The same samples were analyzed using the electron capture detector which is especially sensitive to polynuclear aromatic compounds; these are correlated with the soot load.

Air particulates in an active $U$ mine (sampled last year) and in $U$ ore

* Radiological Sciences Department and diesel exhaust exposure chambers were sampled with Lundgren and Andersen impactors. The stages on which particles of a specific size range impacted, the $U$ ore, and the diesel fuel, are being analyzed for their elemental content by X-ray fluorescence, atomic absorption and neutron activation analysis. Results for seven elements ( $\mathrm{Ti}, \mathrm{V}, \mathrm{Fe}, \mathrm{Cu}, \mathrm{Zn}$, $\mathrm{Pb}$ and $\mathrm{U}$ ) have been obtained by $\mathrm{X}$-ray fluorescence. Concentrations ranged from $0.06 \% \mathrm{Cu}$ to $2.3 \% \mathrm{U}$ in the ore, from $3.9 \mu \mathrm{g} / \mathrm{m}^{3}$ of $\mathrm{Cu}$ to $214 \mu \mathrm{g} / \mathrm{m}^{3}$ of $U$ in the $U$ ore aerosol and were below detection 1 imits ( $50 \mathrm{ppm}$ ) in the diesel fuel and diesel exhaust aerosol $\left(0.1 \mu \mathrm{g} / \mathrm{m}^{3}\right)$. Upper 1imits of about $0.1 \mu \mathrm{g} / \mathrm{m}^{3}$ or lower have also been established for $S, C 1, K, S c$, $\mathrm{Cr}, \mathrm{Mn}, \mathrm{Co}, \mathrm{Ni}, \mathrm{Ga}, \mathrm{Ge}, \mathrm{Se}, \mathrm{Br}$ and $\mathrm{Rb}$ in the exposure aerosols. Almost $70 \%$ of the mineral content of the $U$ ore dust sampled from the exposure chambers was associated with particles of $1 \mu \mathrm{m}$ diameter or smaller, less than $1 \%$ was in particles as 
large as $10 \mu \mathrm{m}$. In contrast with 0.2 to $0.5 \mu \mathrm{m}$ CMD particle distributions obtained in operating mines in 1964, the mineral components of aerosols obtained in an operating $U$ mine sampled this year were mainly associated with larger particles; 5\% occurred in the $0.3 \mu \mathrm{m}$ and smaller range, while $23 \%$ had particle diameters $10 \mu \mathrm{m}$ and larger.

The low pressure type cascade impactor, having a last stage cutoff diameter of $0.06 \mu \mathrm{m}$ for unit density spheres, has been evaluated and applied to the analysis of Rn daughters in simulated $U$ mine aerosols. Radon daughter activity in samples from all three aerosol chambers peaked on the fifth stage $(0.1 \mu \mathrm{m})$ of the six stage impactor. Total RaA was lowest, relative to $\mathrm{RaB}$ and $\mathrm{RaC}$, in the 1200 WL Rn daughter only chamber; yet this chamber had the highest relative level of RaA on the first stage, presumably because of the large unattached fraction of RaA $(30 \%)$. In the presence of higher concentrations of condensation nuclei, less of the RaA was unattached; and a higher portion penetrated to the backup filter. In the presence of diesel exhaust, which is mostly deposited on the fourth and fifth stages, there is more than a tenfold reduction of the activity on the backup filter. The Rn may be absorbed on the carbon particles for time intervals long enough for $\mathrm{Rn}$ daughters to be born attached. 


\section{EVALUATION OF RADIONUCLIDES IN MAN}

This project is concerned with the development and application of methods for evaluating the radiologic impact of the nuclear industry on its workers and on the general public. It includes as subprojects work previously funded under the titles, "Radiological Evaluation of Postmortem Tissue Samples" and "Dosimetry of Radionuclides in Man."

Analyses of postmortem tissue samples from Hanford plant workers and local residents have been conducted on a very limited scale since 1949. The purpose has been to establish baseline quantities of significant radionuclides as distributed within the body and as related to age, occupation, geographic residence, and point in time. Postmortem studies are required because present methods of in vivo measurement do not give adequate data on such important radionuclides as ${ }^{239} \mathrm{Pu}$. Another important aspect of this project is concerned with the development of more sensitive and more accurate techniques for in vivo assessment of internal deposition of radionuclides.

The effort devoted to this project during the past year has been severely curtailed due to the diversion of funds and personnel to the preparation of environmental impact statements.

\section{PUBLICATION}

NELSON, I. C. A Simplified Method for Evaluating the Healy Plutonium Excre- tion Equations. Health Phys., vol. 22, p. 191. 1972. 


\title{
EVALUATION OF POSTMORTEM TISSUE SAMPLES
}

\author{
Investigators: \\ I. C. Nelson and V. W. Thomas, Jr. \\ Technical Assistance: \\ D. T. Harless
}

Present studies are an outgrowth of efforts conducted on a limited scale since 1949. Collection of postmortem tissue samples (lung, liver, bone and tracheobronchial lymph nodes) from individuals residing or formerly residing in the vicinity of the Hanford complex continued during the past year. Postmortem tissue samples and blood samples were also received from the U.S. Transuranium Registry for whom analyses are performed.

In June, 1972 , the analytical laboratory was moved to more permanent quarters. Renovation, clean up, and investigation of background levels prevented resumption of sample analyses until November. By year end, 22 Registry samples and 44 environmental samples had been processed to completion; 49 Registry samples were in process, and 53 Registry and about 100 Environmental samples were awaiting processing. Similar work is being done at the Los Alamos Scientific Laboratory (LASL). The LASL and Pacific Northwest Laboratory programs provide for needed mutual redundancy in laboratory capability; frequent communication and interlaboratory comparison of calibrations and checks provide a unique basis for the establishment of state-of-the-art measurement techniques and interpretive analysis. Both laboratories process samples for the Registry, and both conduct their own regional program of postmortem tissue analysis. The LASL will coordinate processing of samples collected at selected locations around the nation.

\section{DIAGNOSIS OF PROMETHIUM HAZARD IN MAN}

Investigators:

I. C. Nelson, D. B. Shipler,

J. E. Ballou and B. I. Griffin

For diagnosing the retention of ${ }^{147} \mathrm{Pm}_{2} \mathrm{O}_{3}$ in accidentally exposed workers, human data on the retention of inhaled Pm are badly needed. Exposure of human volunteers to the 
readily detectable ${ }^{143} \mathrm{Pm}$ seems feasible, providing a suitable carrier can be found which will provide the necessary mass and which will behave in the body like Pm. Samarium has been proposed as such a carrier and experiments comparing the behavior of intravenously injected and inhaled $\mathrm{Sm}$ and $\mathrm{Pm}$ in rats were described in last year's Annual Report. The results of these rat studies indicate

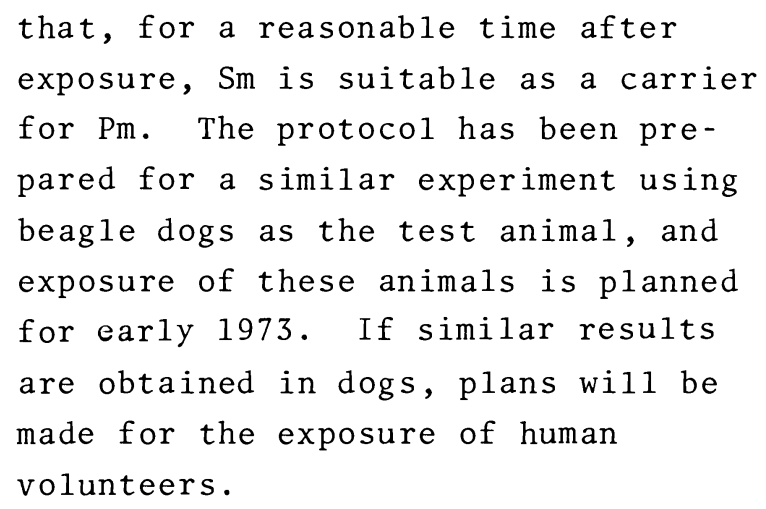


REMOVAL OF RADIONUCLIDES

The general objective of this project is to develop methods that will hasten the removal, prevent the deposition, or otherwise decrease the damage potential from ingested, absorbed, or inhaled radionuclides. Necessarily associated with this effort is the development of information on the absorption, translocation, mobilization, and tissue distribution of radionuclides to help in understanding and predicting their behavior and to serve as a basis for recommendations for the treatment of exposed persons. Further, this project seeks to be responsive to the practical needs of those persons responsible for the treatment of external or internal radionuclide poisoning, to act in a supportive role in examining hazards of biologic, medical and technical applications of radionuclides, and to try to anticipate problems associated with human involvement in nuclear industry and defense.

\section{PUBLICATIONS}

HUNGATE, F. P., J. E. BALLOU, D. D. MAHLUM, M. KASHIMA, V. H. SMITH, C. L. SANDERS, D. W. BAXTER, M. R. SIKOV, and R. C. THOMPSON. Preliminary Data on $253 \mathrm{Es}$ and $249 \mathrm{BK}$ Metabolism in Rats. Health Phys., vol. 22, p. 653. 1972 .

MCDONALD, K. E., J. F. PARK, R. J. OLSON, R. H. BUSCH, and C. L. SANDERS. Removal of Inhaled $239 \mathrm{PuO}_{2}$ from Beagle Dogs by Pulmonary Lavage. Health Phys., vol. 23, p. 425. (A bstract). $\overline{1972}$.

SMITH, V. H. Comparison of Efficiency of Removal of Plutonium, Cerium and Zine from Rats by $C a-$ and $2 n-D T P A$. Radiat. Res., vol. 51, p. 540

(Abstract). 1972 .
SMITH, V. H. The Effect of Mass on Promethium Retention and Removal from the Rat. Health Phys., vol. 23, p. 31. $19 \overline{72}$.

SMITH, V. H. Metal-DTPA Chelates in Biological Systems - A Bibliography. BNWL-1657, Battelle, Pacific Northwest Laboratories, Richland, WA. 1972.

SMITH, V. H. Some Aspects of Chelation Therapy for Internal Contamination with Actinide Elements. Health Phys., vol. 23, p. 425 (Abstract). 1972 .

SMITH, V. H. Therapeutic Removal of Internally Deposited Transuranium Elements. Health Phys., vol. 22, p. 765 . 1972 . 


\title{
PATHOLOGIC EFFECTS OF INHALED DTPA
}

\author{
Investigators: \\ J. E. Ballou, R. H. Busch, D. K. Craig, \\ and V. H. Smith \\ Technical Assistance: \\ W. G. Morrow and M. D. Snyder
}

\begin{abstract}
With the possible exception of a transient emphysema, no pathology was observed in rats or hamsters attributable to inhaled CaNa3-DTPA at absorbed doses of 1 to 10 times the customary dose.
\end{abstract}

To check for early pathology associated with Ca-DTPA inhalation, male, adult Wistar-stain rats and Golden Syrian hamsters, 225 of each, were exposed nose-only to aerosols generated from medica $1-$ grade, $25 \%$ Ca-DTPA (Geigy) by a typical human inhalation therapy nebulizer. Animals were exposed for either 1 or 2 hr three times in $1 \mathrm{wk}$, and comparisons were made with animals exposed similarly to physiological saline aerosols, with sham-treated animals kept in chambers for $2 \mathrm{hr}$ with no aerosol, and with shelf-control animals receiving no treatment or handling. The absorbed DTPA dose was estimated from chemical analyses of DTPA in urine and based on literature reports that intravenously injected DTPA is about 99\% excreted via the kidneys. Aerosols in the rat exposure chamber averaged $4.7 \mathrm{mg}$ DTPA/1., $3.25 \mu \mathrm{m} \mathrm{MMAD}$ (mass median aerodynamic diameter), $2.4 \sigma_{g}$ and in the hamster exposure chamber, $3.9 \mathrm{mg}$ DTPA/1., $3.96 \mu \mathrm{m} \mathrm{MMAD,}$ $2.4 \sigma_{\mathrm{g}}$. Absorbed doses were estimated at $4.5 \pm 0.36$ and $8.0 \pm 0.51$ $\mathrm{mg}$ DTPA to rats and $2.1 \pm 0.26$ and $5.4 \pm 0.68 \mathrm{mg}$ DTPA to hamsters after the 1 and 2 hr exposures, respectively. This represents about 4 to $10 \mathrm{mg}$ DTPA/g lung in these animals or a dose of 14 to $24 \mathrm{mg}$ DTPA/kg body weight in the rats and 21 to $54 \mathrm{mg}$ DTPA/kg body weight in hamsters. If the $1 \mathrm{~g}$ of DTPA given humans is $100 \%$ absorbed from the lung, corresponding values for the human are $1 \mathrm{mg}$ DTPA/g lung and $14 \mathrm{mg} / \mathrm{kg}$ body weight. The human more likely absorbs about $25 \%$ of the DTPA deposited in the lung so that the animal doses represent 4 to 12 times the customary human dose. Five animals from each of the five groups were killed after the first and third exposure and every 7 days for the following $5 \mathrm{wk}$. The lungs, liver, kidneys, spleen, adrenals, turbinates, trachea, esophagus, stomach, duodenum, jejunum, ileum, eyes, and large intestine were examined histologically. The only observed pathology definitely ascribable to the DTPA was a transitory vesicular emphysema (Table 1). This was diagnosed in $9 / 20$ rats and $10 / 20$ hamsters through the third exposure and was still present 7 days after exposure 
TABLE 1. Observed Pathology in Rats and Hamsters After Inhaling $\mathrm{CaNa}_{3}$-DTPA

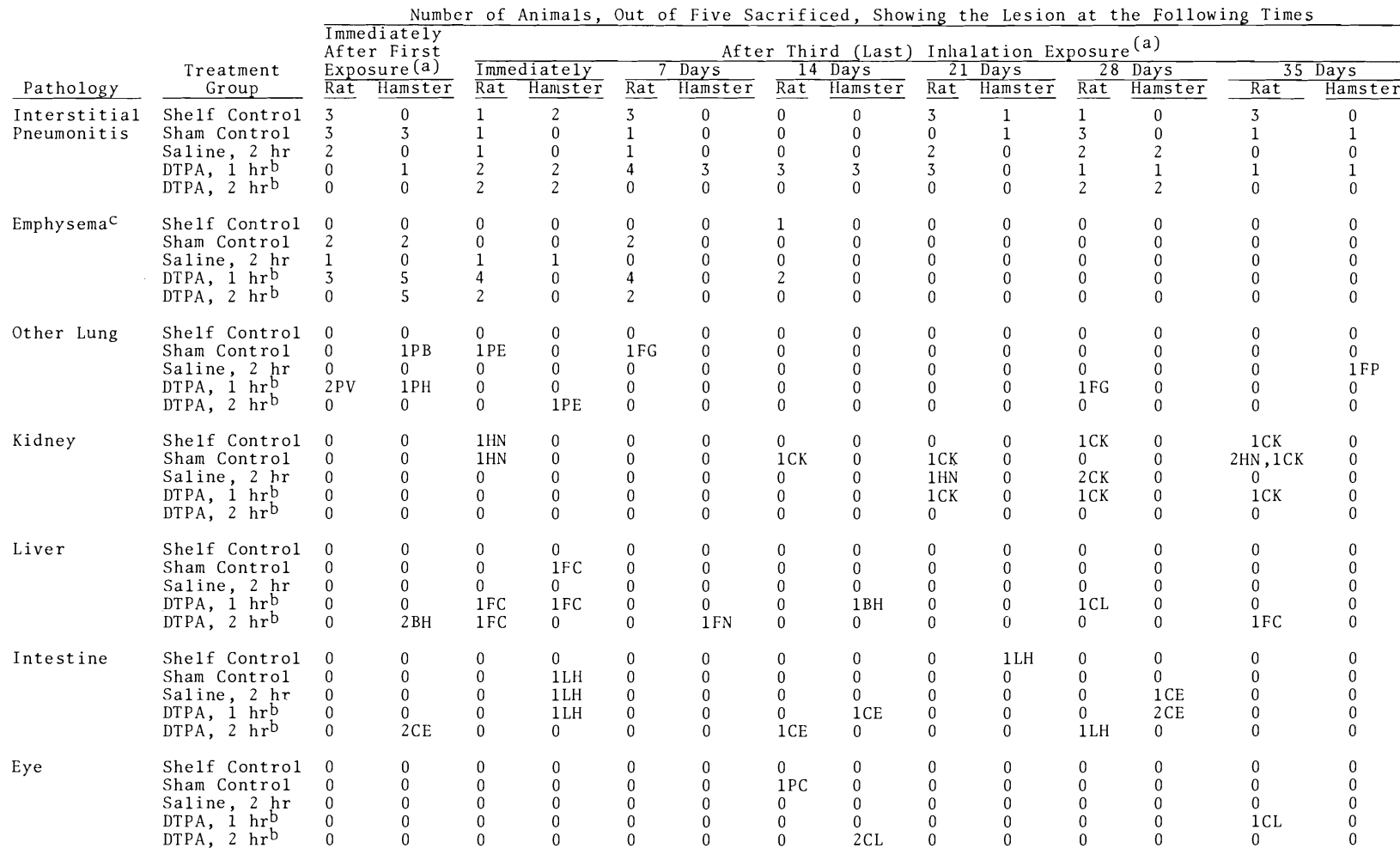

abbreviations:

BH Bile duct hyperplasia CY Cystic Liver FP Focal pneumonitis PC Pannus of cornea

CE Chronic enteritis FC Fatty change HN Hydronephrosis PE Pulmonary edema

CK Cystic kidney FG Focal granuloma LH Lymphoid hyperplasia PH Hemorrhage

CL Corneal lesion FN Focal necrosis PB Peribronchiolitis PB Perivascular edema

bestimated dose from $1 \mathrm{hr}$ aerosol exposure: $3 \mathrm{~g}$ CaNa 3 -DTPA/kg lung to rats; $2.1 \mathrm{~g} / \mathrm{kg}$ to hamsters. The dose is given per

c pathogenically this is a transient emphysema, mainly vesicular in morphological aspects, and is common early in inhalation

experiments in these animals. As is the case here, the lesion is usually repaired.

in 6/10 rats but in none of the hamsters. Recovery was complete in both species by 3-wk postexposure. No weight changes significantly different from the controls were observed in any of the groups.

Doses up to 10 times the $1 \mathrm{ike} 1 \mathrm{y}$ human dose and exposures 2 to 8 times longer than used in humans induced only a transitory emphysema in the rat and hamster. It is not known whether such a phenomenon might aggravate pre-existing lung problems, but caution is indicated until such factors can be explored. 


\title{
DISTRIBUTION AND RETENTION OF ${ }^{14}$ C-LABELED EDTA IN RATS
}

\author{
Investigator: \\ V. H. Smith \\ Technical Assistance: \\ M. D. Snyder
}

\begin{abstract}
The rate of appearance in rat urine of inhaled CaNa2-EDTA is retarded compared with intravenously administered EDTA. Assuming that urinary excretion mimics blood levels, inhaled chelating agents should be available for metal decorporation over longer time periods than injected chelating agents.
\end{abstract}

Studies with ${ }^{14} \mathrm{C}$-1abeled DTPA are needed to confirm the analytical methods employed for DTPA and to obtain more precise data on its translocation and clearance following inhalation or injection. A preliminary study was made with ${ }^{14} \mathrm{C}$-EDTA, mainly to gain experience before utilizing the more expensive ${ }^{14} \mathrm{C}$-DTPA. The two agents DTPA and EDTA, may be expected to show very similar results.

Female rats with indwelling urethral catheters were injected with, or exposed to aerosols of, ${ }^{14} \mathrm{C}$-EDTA. Inhalation exposures were for $30 \mathrm{~min}$ to an aerosol concentration of $10 \mathrm{mg}$ $\mathrm{CaNa}_{2}-\mathrm{EDTA} / 1$. (3.48 $\mathrm{mm}$ MMAD, $2.20 \sigma_{\mathrm{g}}$ ). The absorbed dose varied from 5.5 to $11 \mathrm{mg} \mathrm{CaNa}_{2}$-EDTA. Following exposure by inhalation, about $50 \%$ of the absorbed chelating agent was excreted by the fifth hour, $90 \%$ in $24 \mathrm{hr}$ and $99 \%$ in $72 \mathrm{hr}$ postexposure. In contrast, rats intravenously administered $50 \mathrm{mg}$ EDTA excreted $50 \%$ in the first hour, at least $90 \%$ by the fifth hour, and $99 \%$ by $24 \mathrm{hr}$ postinjection. Concentrations in the urine were as high as $25 \mathrm{mg}$ EDTA $\mathrm{ml}$ after the intravenous dose, but about a tenth of that level after inhalation administration. There is no doubt that the inhaled chelating agent was present at therapeutically significant concentrations for a longer time than the injected EDTA, assuming that the urine output reflects the blood concentration. Concentration in the urine $24 \mathrm{hr}$ after administration was 10 times 1 ess for the 10-fold higher intravenous dose than for the inhaled dose, $0.3 \mathrm{mg}$ EDTA/ml urine at $24 \mathrm{hr}$. These results point to an interaction of the chelating agent with the lung, slowing absorption beyond that expected for such a freely water-soluble compound.

Since absorption from the gut could be a factor in the amount of chelating agent reaching the blood after inhalation, rats were administered ${ }^{14} \mathrm{C}$-EDTA by stomach tube; and the urine collected via catheter. Maximum absorption was reflected in the urine after about 1 to $3 \mathrm{hr}$, perhaps coincident with residence in the stomach and small intestine, with a concentration in urine of about 0.4 $\mathrm{mg}$ EDTA/m1 from a dose of $25 \mathrm{mg}$. 
Total absorption was $<3 \%$ of the dose, in accord with previous estimates of others. These results indicate a minor, but significant contribution from gut absorption following inhalation of a chelating agent. Thus, if $250 \mathrm{mg}$ is directly absorbed, of the $1000 \mathrm{mg}$ assumed deposited in the lung of a human, $3 \%$ of the $750 \mathrm{mg}$ assumed to be swallowed would account for $22 \mathrm{mg}$ absorbed from the gut, or about
$10 \%$ of the total absorbed.

A much improved method for the bladder catheterization of female rats was developed in the course of these studies. The catheter is inserted from the bladder through the urethra. This technique is very useful for following the kinetics of passage through the kidney and appearance in urine of materials administered by various routes.

LONG-TERM EFFECTS

OF DTPA TREATMENT OF PLUTONIUM DEPOSITION IN RATS

Investigator:

J. E. BaZZou

Technical Assistance:

W. G. Morrow

Delayed DTPA inhalation administered 20 days after inhaled $\mathrm{Pu}\left(\mathrm{NO}_{3}\right)_{4}$ decreased the body burden of $\mathrm{Pu}$ to about one-half the sham-treated control value.

There has been some evidence in the Russian 1iterature that DTPA combined with the insult of Pu might be more damaging over the long term than either agent alone. As part of an extensive study of the carcinogenicity of inhaled $\mathrm{Pu}\left(\mathrm{NO}_{3}\right)_{4}$, six weekly treatments of inhaled DTPA were given to rats starting 20 days after $\mathrm{Pu}$ inhalation, with animals sacrificed periodically over their lifetime for pathologic examination. A total of 400 rats were employed in this phase of the study. Aerosols of ${ }^{239} \mathrm{Pu}\left(\mathrm{NO}_{3}\right)_{4}$ were generated from a $0.27 \mathrm{~N} \mathrm{HNO}_{3}$ solution. Groups with Pu- or DTPA-only, and sham treatment groups are included.
As expected, DTPA treatments decreased the Pu content of soft tissues and bone compared to the amounts found in sham treated controls (Figure 1). Little or no $\mathrm{Pu}$ was anticipated to be removable from the lung by the delayed treatment with DTPA. However, after the series of 6 DTPA treatments the lung burden tended to be reduced to about $70 \%$ of that in sham-treated rats although the results are only marginally significant at this time interval. The total rat burden was reduced by half. No gross pathologic response has been observed in the DTPA-treated rats out to 200 days; histopathology results are not yet available. 


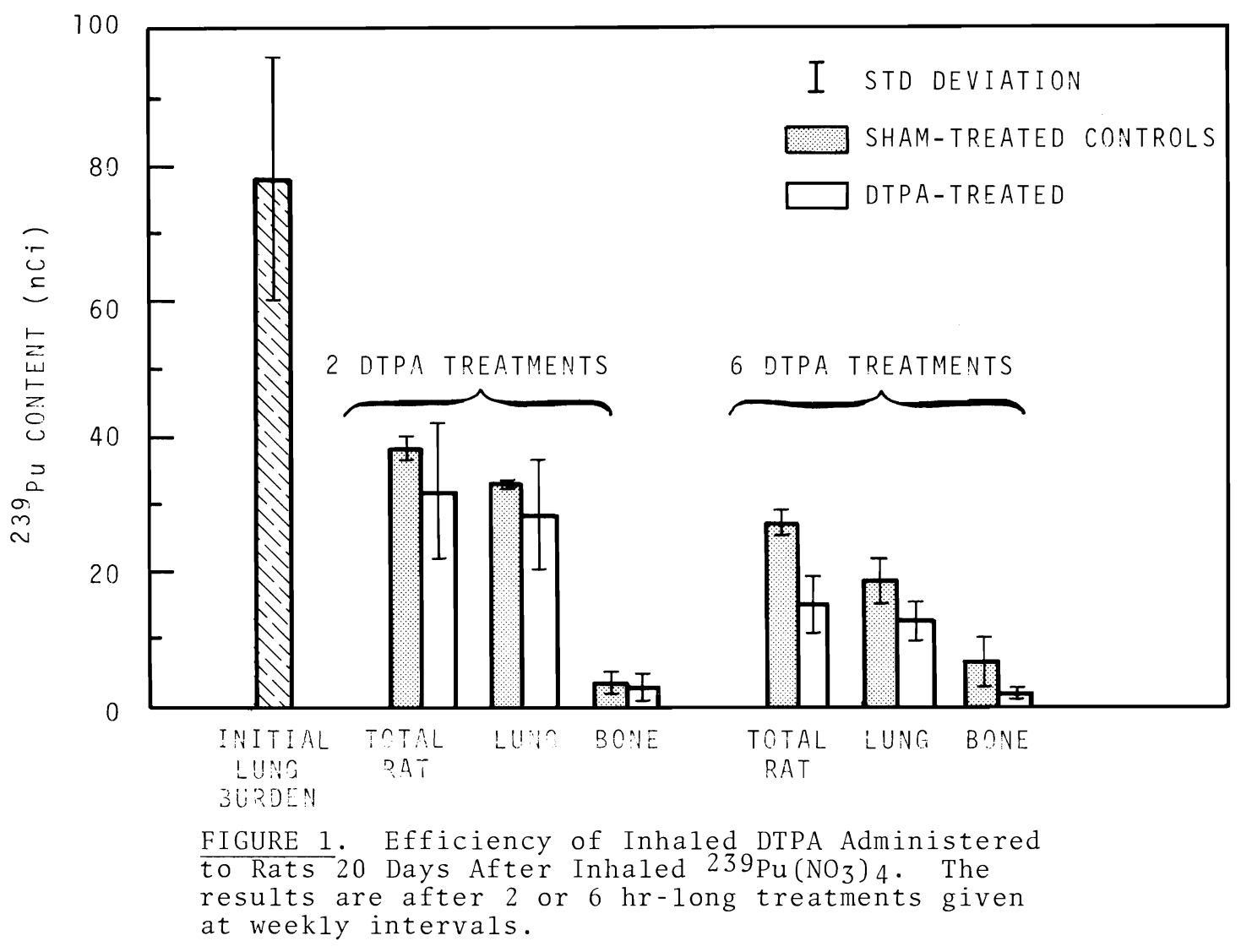

EFFECT OF FASTING ON REMOVAL OF PLUTONIUM BY DTPA

Investigator:

C. L. Sanders

Technical Assistance:

Doris M. Meier

\begin{abstract}
Metabolic alterations due to fasting had no effect on the biologic deposition of $239 \mathrm{PuO}_{2}$ injected intraperitoneally in rats or on decorporation of Pu with DTPA.
\end{abstract}

Fasting causes many metabolic changes such as depletion of body energy stores, decreased basal metabolic rate, urinary ketosis and an increased urinary excretion of $P, S$ and Ca. Such changes might interfere with $\mathrm{Pu}$ absorption into tissues or effect the release of already bound $\mathrm{Pu}$ and thus be useful in conjunction with chelation therapy in the the removal of $\mathrm{Pu}$. 
Plutonium-238, as a 'soluble' form derived from crushed, plasma torchprepared ${ }^{238} \mathrm{PuO}_{2}$ microspheres which had been stored in water, was injected intraperitoneally in 70 rats. Some of the rats were fasted for the first 10 days following $\mathrm{Pu}$ injection and either not treated or treated with $0.5 \mathrm{mmol}$ DTPA at the beginning or at the conclusion of the fasting period. Other animals were maintained as nonfasted but variously treated controls. Fasting alone had no effect on the distribution or excretion of the Pu compared to the fed controls; both groups re- tained about $60 \%$ of the injected $\mathrm{Pu}$ at 30 days. Neither was the effectiveness of DTPA treatments enhanced by fasting, retention being decreased to about $10 \%$ when treatments were initiated ear $1 y$ and to about $40 \%$ when initiated after the fasting period in both fed and fasted rats. These results reflect the predominantly physical-chemical nature of $\mathrm{Pu}$ uptake and distribution in tissues and are in line with other results showing a general lack of response of the boneseeking, nonphysiologic metals to metabolic alterations.

\section{DTPA-ENHANCED PLUTONIUM EXCRETION VIA THE BILE}

Investigator:

M. F. Suzzivan

Technical Assistance:

A Zma Crosby

DTPA enhanced the biliary excretion of both monomeric and polymeric $239 \mathrm{Pu}$; it was almost twice as effective for monomeric.

An experiment was performed to determine the influence of the physical-chemical state of injected ${ }^{239} \mathrm{Pu}$ on its subsequent excretion in the bile before and after treatment with DTPA. The common bile duct of rats was cannulated, and the animals placed in a Bollman-type restraining cage. They were injected with either monomeric or polymeric ${ }^{239} \mathrm{Pu}$, and a complete collection of bile was made. An average of $1.8 \%$ of the monomeric ${ }^{239} \mathrm{Pu}$ appeared in the bile by the third day; about half that amount of polymeric $\mathrm{Pu}$ appeared in the bile (Figure 1). On the third day, DTPA was injected and bile collection continued. Rats that had received monomeric $\mathrm{Pu}$ excreted an additional $13 \%$ in the bile following DTPA; and those that had received polymeric $\mathrm{Pu}$, an additional $8 \%$. Approximately $21 \%$ of the monomeric and $15 \%$ of the polymeric was excreted into the urine. A small amount, approximately $3 \%$, 
was excreted into the G.I. tract despite bile duct cannulation, indicating that there is direct entry of $\mathrm{Pu}$ from the blood stream into the G.I. tract. Autoradiographs prepared from sections of liver showed fewer stars after injection of the monomer than after injection of the polymer. Autoradiographs prepared from collected bile showed no large particles after injection of either form. Although $\mathrm{Pu}$ retention in the femur was about equal, $2.7 \%$ and $2.9 \%$, respectively, with monomer and polymer, retention in the liver was 2 -fold greater when the polymer was administered. These results indicate that the bile is a more important route of excretion for monomeric than for polymeric $\mathrm{Pu}$.

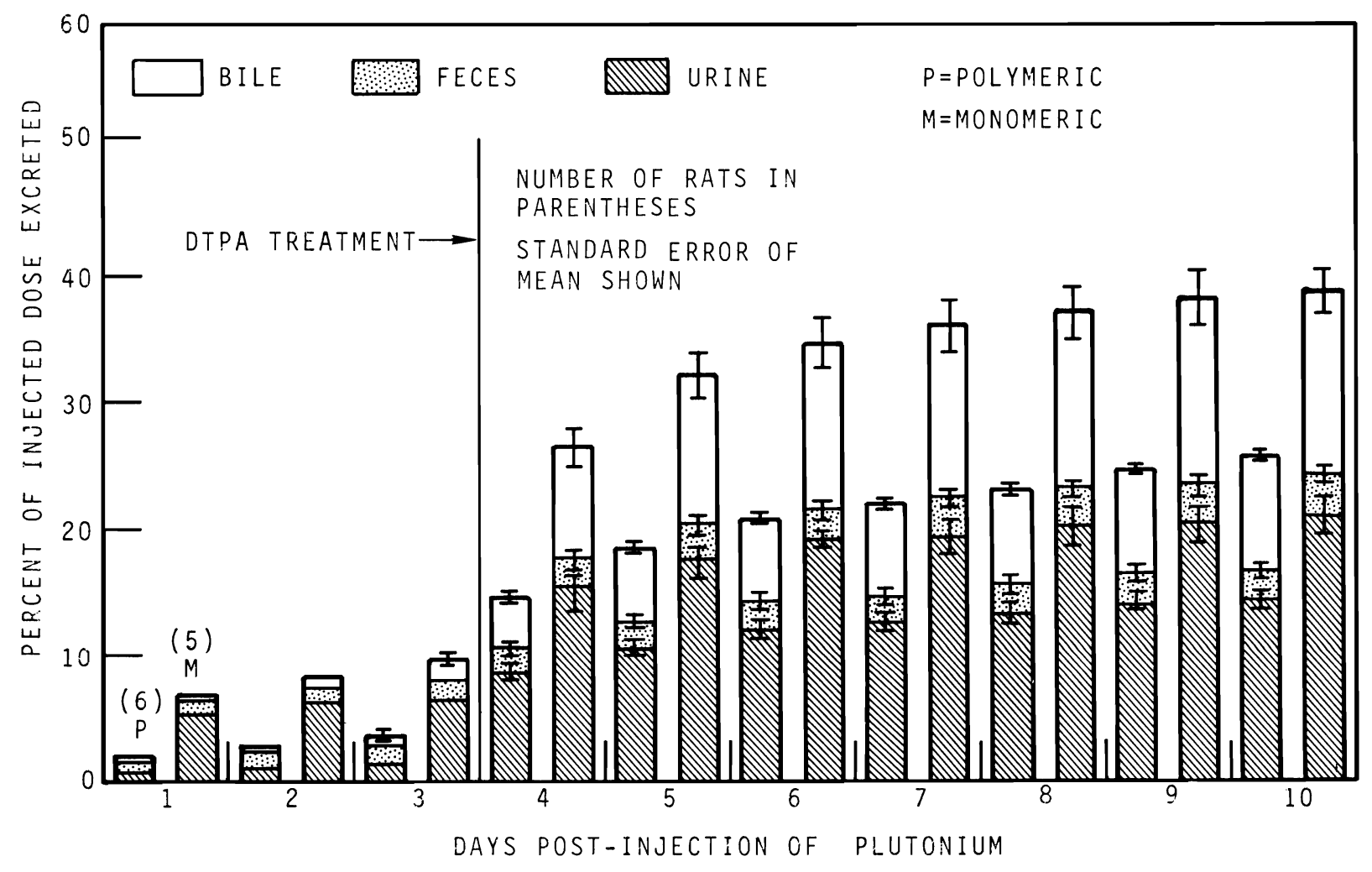

FIGURE 1. Cumulative Excretion After Treatment with DTPA of Either Monomeric or Polymeric $239 \mathrm{Pu}$ 


\title{
CHELATABILITY OF PLUTONIUM IN BLOOD
}

\author{
Investigator: \\ J. E. Bazzou \\ Technical Assistance: \\ W. G. Morrow
}

\begin{abstract}
The fraction of Pu susceptible to chelation by DTPA in whole blood remains fairly constant for about 3 hr after injection. In separated plasma or serum, Pu rapidly becomes less available, suggesting the involvement of formed elements of blood.
\end{abstract}

One of the problems facing the industrial physician is whether to treat an exposed individual and how soon this decision must be made and implemented. In the human and in larger animals, Pu has been found to leave blood fairly slowly; and $\mathrm{Pu}$ while in blood is amenable to chelation therapy. Plutonium present in blood and lung is probably the major target of early DTPA therapy so further knowledge of the very early changes in these systems may suggest new approaches to therapy and aid in establishing the maximum benefit from current regimens. Earlier in vitro studies indicated that $\mathrm{Pu}$ in synthetic lung fluid or blood serum was rapidly polymerized and essentially not available for DTPA chelation after $2 \mathrm{hr}$. This finding has been confirmed also for blood plasma containing the anticoagulant, heparin. However, whole blood studies in vitro and in vivo suggest that $80 \%$ of the chelatable Pu is still available for therapeutic removal $3 \mathrm{hr}$ after injection.

Blood taken from a dog at various times after intravenous or intra- tracheal injection with Pu nitrate or Pu citrate, was heparinized and centrifuged; and the plasma was ultrafiltered using Visking cellulose tubing. DTPA $\left(7 \times 10^{-3} \mathrm{M}\right)$ was added to these samples of blood, and the percent of ultrafilterable $\mathrm{Pu}$ in the plasma was taken as a measure of the amount of Pu available for chelation. Following intravenous injection of $\mathrm{Pu}$ citrate, $\mathrm{Pu}$ in blood was initially 30 to $40 \%$ chelatable; after $3 \mathrm{hr}$ approximately $80 \%$ of the blood was chelatable. However, during this interval the total blood Pu level decreased about $40 \%$, so the net amount of $\mathrm{Pu}$ available for chelation remained fairly constant up to $3 \mathrm{hr}$ after injection. The results after intratracheal injection of $\mathrm{Pu}$ nitrate and $\mathrm{Pu}$ citrate, still very tentative, indicate that blood $\mathrm{Pu}$ is from 50 to $60 \%$ chelatable up to $4 \mathrm{hr}$ after injection. The amount in blood increased 3- to 10-fold for the nitrate and citrate salts, respectively, during the first $4 \mathrm{hr}$ following intratracheal injection.

These data for $\mathrm{Pu}$ in vivo are to be compared with in vitro studies 
where Pu added to plasma with or without heparin became unavailable for chelation at a rapid rate. Plutonium added to heparinized whole blood, on the other hand, remained about $80 \%$ chelatable for at least $3 \mathrm{hr}$. The observation that $\mathrm{Pu}$ appears to be stabilized for DTPA chelation in whole blood and not in serum or plasma suggests that the formed elements in blood may be active in slowing the rate of $\mathrm{Pu}$ polymerization or in promoting $\mathrm{Pu}$ binding in readily chelatable forms. Essentially no Pu is recovered with the red cell fraction after centrifugation, suggesting that the stabilizing effect may be related to the cell surface or perhaps involve a metabolic product of the blood cells.

More work is required before recommendations can be made concerning human therapy; however, it seems likely that DTPA therapy could be delayed as much as $3 \mathrm{hr}$ after $\mathrm{Pu}$ incorporation without undue loss of effectiveness in removing $\mathrm{Pu}$ from blood. While other actinides and lanthanides would be expected to behave similarly, the behavior of $\mathrm{Pu}$ may be unique at least in practice; and until the experiments are carried out, delays in treatment should be avoided.

\title{
RADIOLYTIC EFFECTS ON CHELATABILITY OF PLUTONIUM OXIDE
}

Investigator

V. H. Smith, J. F. Park, and D. K. Craig

Technical Assistance:

M. D. Snyder

\begin{abstract}
Ultrafiztration of Pu oxides, stored as aqueous suspensions, reveals increased solubility with time for the higher specific activity isotope $238 \mathrm{Pu}$. Complexing by DTPA is facilitated by the radiolytic degradation of the oxide and by length of contact time.
\end{abstract}

The success of chelation treatment for removing 'insoluble' radionuclides and the scheduling of such treatments is to a great extent dependent on the solubility and subsequent availability of a chelatable form of the radionuclide. Ultrafiltration was employed to study whether there were changes in solubility and complexation behavior of various plutonium oxide suspensions after storage in water. It seems likely such changes would be associated with possible radiolytic degradation of the oxide and its environment and would be more rapidly incurred by high specific activity isotopes such as ${ }^{238} \mathrm{Pu}$. If this occurs in vivo, translocation rates and availability for chelation therapy would be affected.

It was found that ${ }^{239} \mathrm{PuO}_{2}$, prepared from oxalate fired at $750^{\circ} \mathrm{C}$ for 
$2 \mathrm{hr}$ and suspended in water at a concentration of $0.1 \mathrm{mCi} / \mathrm{ml}$, was about $0.2 \%$ ultrafilterable (u.f.) through membranes with $\sim 28 \AA$ pores over a period of at least $1 \mathrm{yr}$. Plutonium238 oxide, prepared in the same manner and suspended in water at a concentration of $1.1 \mathrm{mCi} / \mathrm{ml}$, was found to be $25 \%$ u.f. after 6 months. If membranes with $80 \AA$ pores were used, the ${ }^{239} \mathrm{PuO}_{2}$ was still only $0.2 \%$ u.f.; but the ${ }^{238} \mathrm{PuO}_{2}$ was $60 \%$ u.f. When a freshly prepared suspension of ${ }^{238} \mathrm{PuO}_{2}$ was tested, it showed $0.2 \%$ u.f., the same as for the ${ }^{239} \mathrm{PuO}_{2}$; but by the third day after preparation it was $0.4 \%$ u.f.; by the ninth day it was $1.7 \%$; by 35 days it was $12 \%$, and after 2 months it was $15.8 \%$ u.f. When DTPA $(0.002$ mmoles $/ \mathrm{ml}, \mathrm{pH} 4)$ was added to a 6-month-old suspension of ${ }^{238} \mathrm{PuO}_{2}$, the u.f. was found to be $36 \%$ after a contact time of 1 to $6 \mathrm{hr}$, compared to $25 \%$ in the absence of DTPA. After $35 \mathrm{hr}$ contact, the u.f. had increased to $46 \%$. This finding demonstrates the increased chelatability of the Pu when altered presumably by intense radiolysis reactions. With old ${ }^{239} \mathrm{PuO}_{2}$ suspensions u.f. increased sharply in the presence of DTPA to $2.2 \%$ at $6 \mathrm{hr}$ and to $5.3 \%$ after $35 \mathrm{hr}$ contact. These studies indicate that, if this radiolytic breakdown and increased susceptibility to chelation occurs in vivo, one may expect some beneficial effect of chelate therapy regardless of the supposed refractory nature of the incorporated material.

\title{
REMOVAL OF PLUTONIUM BY PULMONARY LAVAGE
}

Investigator:

K. E. MeDonazd

\begin{abstract}
The removal of inhaled ${ }^{239}{ }^{\mathrm{PuO}}$, from the rat lung during a single lavage session was improved by the use of hypertonic NaCl or Triton X-100. Little lung pathology was noted in dogs ascribable to 19 weekly lavage sessions.
\end{abstract}

The removal of insoluble Pu from the lung by pulmonary lavage was reported last year to be about $50 \%$ efficient in dogs after 19 weekly lavage sessions beginning 8 days after exposure to ${ }^{239} \mathrm{PuO}_{2}$. The pathologic consequences of this treatment have subsequently been evaluated. Lavage was performed on the right side only, the left side serving as control. After the last lavage treatment, one dog was sacrificed immediately, one after $24 \mathrm{hr}$, one after $48 \mathrm{hr}$ and one after 7 days. All lavaged lungs showed an increased goblet cell production. The animal killed immediately postlavage had chronic bronchitis in one of the washed lobes. 
The dog sacrificed at $24 \mathrm{hr}$ showed signs of edema in one of the lavaged lobes. Differences in fluid content between lungs of the lavaged dogs and of controls appeared radiographically at times up to 5 to $6 \mathrm{hr}$ after lavage but were not found at later times. No lung damage was observed at $48 \mathrm{hr}$ and at 7 days postlavage.

Humans would probably not be subjected to more than one lavage session per lung; therefore, efforts are being made to improve the efficiency of a single session. Screening experiments are being done with rats; the more promising agents will be tested in dogs. Rats receive ${ }^{239} \mathrm{PuO}_{2}$ by inhalation; 7 days later their lungs are lavaged with the test solution; they are killed, and the lungs and lavage fluid analyzed for Pu. Physiological saline is the reference wash solution. Some of the agents tested include dimethylsulfoxide (DMSO) and DMSO + DTPA, to see if the membrane-penetrating effects of DMSO would be beneficial; $0.25 \%$ sucrose, to see if solution density might be a factor in loosening the macrophages containing $\mathrm{Pu} ; \mathrm{KCl}, 1.8 \% \mathrm{NaCl}$, and water, to see if tonicity is a fac- tor; and Pluronics and Triton X-100, to see if surfactant activity might be useful. The effects of temperature variation were also tested since hypothermic solutions are useful in the harvest of macrophages from the liver. There are eight rats per treatment group. The reference wash solution, $0.9 \% \mathrm{NaC} 1$, removes 10 to $16 \%$ of lung plutonium in a single lavage session. Removal was increased about $50 \%$ with Triton $\mathrm{X}-100$ or with $1.8 \% \mathrm{NaCl}$; and the combination of the two doubled the amount removed. Wash solutions at $4^{\circ} \mathrm{C}$ or $50^{\circ} \mathrm{C}$ were no more effective than bodytemperature solutions. Water or sucrose lavage removed only about $3 \%$ of the lung Pu. Addition of pronase to saline essentially blocked Pu removal. The amount of $\mathrm{Pu}$ removed was usually in direct proportion to the number of macrophages in the recovered wash solutions. Improvement in lavage efficiency does appear to be possible with relatively innocuous agents. Efforts will continue in this area, since lavage is the only method currently available for removing insoluble, particulate, Pu from the lung. 


\section{NUCLEAR-POWERED PROSTHESES AND OTHER HUMAN APPLICATIONS}

This project is currently involved in the study of two applications of radioisotopes to medicine and surgery. The first of these studies is concerned with describing the biological effects of intracorporeal radioisotope heat sources. Fifty-watt ${ }^{238} \mathrm{Pu}$ heat sources, such as those designed for use in cardiac-assist/replacement systems, will be implanted in miniature swine. These swine will be observed for possible long-term effects of the added heat and radiation.

The second study is concerned with the development and evaluation of blood irradiators. Radionuclide irradiators suitable for intra-arterial implantation or portable extracorporeal use will be designed, and their performance tested in beagle dogs. Such portable or implantable blood irradiators should be useful in the treatment of leukemic states and in the prevention of allograft rejection.

\section{PUBLICATION}

DECKER, J. R. and M. F. GILLIS. A Completely Implantable Three Channel
Temperature Biotelemetry System. Biomed. Sci. Instrum., vol. 9, p. 133. 1972 . 
OF INTRACORPOREAL RADIOISOTOPE HEAT SOURCES

\author{
Investigators: \\ M. F. Gizlis, J. R. Decker, W. K. Winegardner, * \\ M. T. Karagianes, and F. T. Cross** \\ Technical Assistance: \\ R. D. Carmichael and Linda G. Smith
}

Earlier work established surgical methods for fixing heavy implants in the dorsal thorax of swine, developed telemetry circuitry for monitoring internal heat exchanger temperatures in free-ranging animals, and perfected apparatus and surgical procedures required for the cooling of a source-containing heat exchanger and for its rapid transfer to the thoracic aorta. Two surgical control animals were implanted with thoracic heat exchangers in their descending aorta, containing lead slugs to mimic the anticipated heat source mass (Figure 1). These two animals continue on experiment at this time.

Progress toward implantation of an actual source was delayed by unavailability of the first $50-W{ }^{238} \mathrm{Pu}$ source. One source has now been received, and its incorporation in the thoracic heat exchanger preparation will take place soon. In the meantime telemetry performance was refined and trials of circuitry performance carried out in the body cavities of animals killed for other reasons. In liaison with extradepartmental engineering personne1, a sham

* Mechanical Engineering Department

* Radiological Sciences Department transdiaphragmatic heat conduit source assembly was designed and fabricated. This device, mocking a typical system providing passive transfer of heat from an abdominally located heat source to a thoracic heat exchanger, will be ready for implantation following addition of necessary fabrics for tissue ingrowth.

The maximum heat flux tolerable at a device-tissue interface for direct conduction on a long-term basis is not known. Work by Pierce Foundation with flat plates in the abdomen of sheep established that $0.03 \mathrm{~W} / \mathrm{cm}^{2}$ is tolerable. The question is important since the simplest animal preparation for the long-term study of effects of radiation from an abdominally located radioisotope heat source is that in which'the source is cooled by capillary blood flow in adjacent tissue. To study the surgical feasibility of such an approach, a 5-in. diameter silastic sphere weighing $21 \mathrm{~b}$ was covered with nylon velour fabric and implanted retroperitoneal1y in the abdomen of a miniature swine. Hea1ing was rapid and without incident except for a single small peritoneal adhesion to the large intestine found at postmortem examination 3 month 1 ater. This massive implant did not 


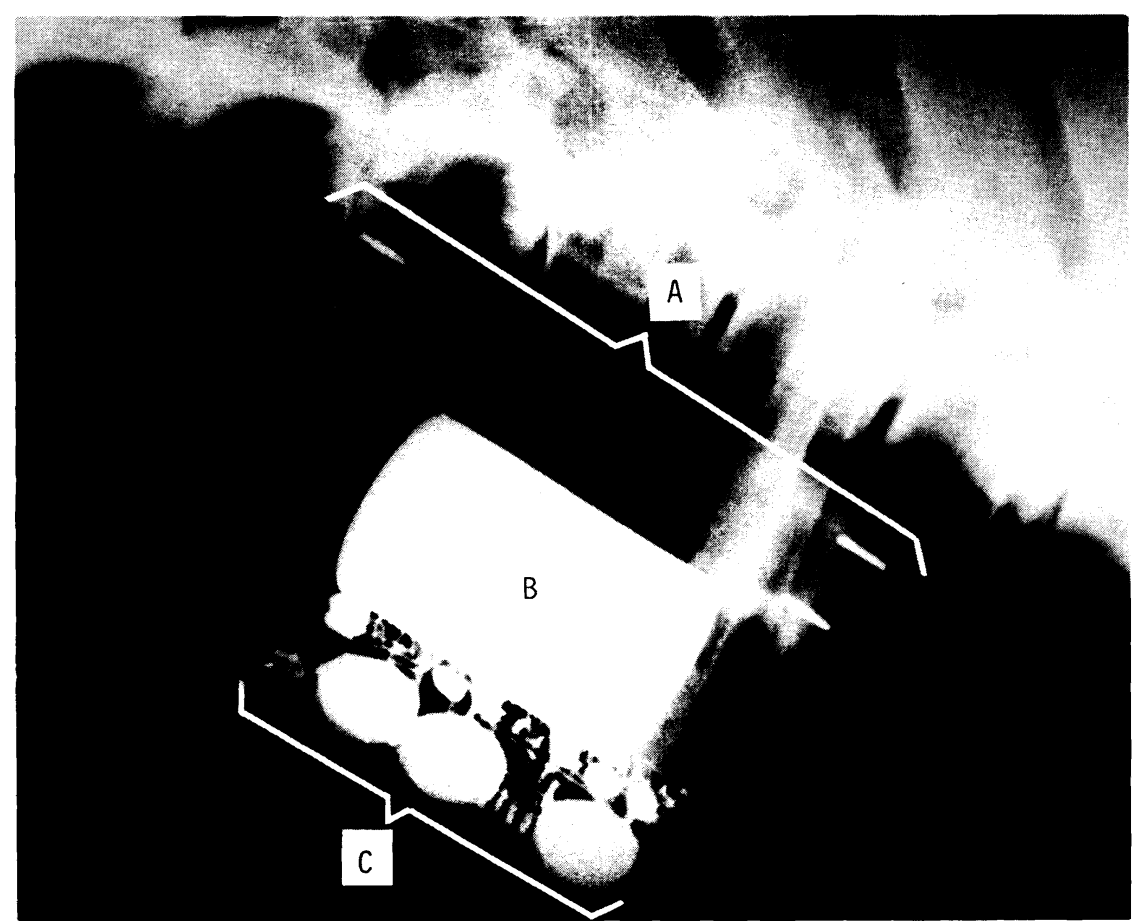

FIGURE 1. Lateral Radiogram of Swine Thorax Immediately Following Heat Exchanger Implantation. The animal's head is to the right. A. Blood flow lumen. B. Heat source. C. Temperature telemetry package.

migrate or produce deleterious effects. Such a sphere containing a $50-$ or $30-W$ source would have an average surface heat flux of 0.10 or $0.06 \mathrm{~W} / \mathrm{cm}^{2}$, respective $1 \mathrm{y}$.

Engineering studies on designs for radioisotope heat source containment are in progress. The abdominal sphere approach is attractive for at least two reasons, the first being that current cardiac replacement system designs call for locating the power subsystem, including its heat source, in the abdominal cavity. The second reason relates to the use of direct conduction of heat into tissues, if possible, rather than relying on blood flowing through tubes as a coolant, as in the thoracic (aortic) heat exchangers. Thrombus formation and occlusion threaten the longevity of nonporous, rigid vascular implants of any kind. In this regard we borrowed techniques developed in other research programs at this laboratory and fabricated a simple tube of porous, surface-passivated titanium alloy, the intent being to provide a surface on which a "pseudoendothelium" could develop and adhere. Because of its composition, the surface should conduct heat better than the usual polymer flocks and velours currently used for vascular prostheses. This tube was implanted in the thoracic 
aorta of a miniature swine and examined a month later. The results were extremely encouraging, as there was no evidence of iris-type thrombi near its ends, a consistent finding whenever nonporous tubes are so im- planted. We hope to further explore this approach, in the event that we must use intravascular heat exchangers for heat source implantation in this program.

\section{DEVELOPMENT AND EVALUATION OF BLOOD IRRADIATORS}

Investigators:

F. P. Hungate, B. I. Griffin, *

J. H. Jarrett, ** and M. F. Gillis

Technical Assistance:

D. L. Catt, W. R. Riemath, † and Linda G. Smith

A ${ }^{204}$ T1 blood irradiator has now been implanted in the thoracic aorta of a beagle dog for more than a year. The initial dose to dog blood was slightly more than 10 rads per day; final dose rate will be evaluated when the irradiator is removed at sacrifice. This dog has shown no change in either small or large 1ymphocyte levels nor change in migration of peripheral blood cells when challenged in vitro with an appropriate antigen, and skin allograft rejection time was not prolonged.

A new type of irradiator, consisting of a 2 -inch stainless steel wire coated in its mid segment with ${ }^{238} \mathrm{Pu}$ covered by a thin layer of $\mathrm{Pt}$, was implanted in the aorta of a dog by inserting the wire diagonally through

* Radiological Sciences Department * Chemical Technology Department

+ Fuels and Materials Department the vessel and suturing the wire in place at both ends. The implant was successful in that both the irradiator and its control were implanted directly into the blood stream with no apparent deleterious effects. The dose to dog blood from the irradiator is not precisely known but was designed to be in the range of 50 to $100 \mathrm{rads} / d a y$. Depending on the condition of the wire, dosimetry may be attempted when it is retrieved from the animal. Some loss of radionuclide has occurred as evidenced by ${ }^{238} \mathrm{Pu}$ in the urine and feces. This irradiator has been in place for 6 months. No change has been observed in lymphocyte levels nor in mobility of peripheral cells challenged by antigen in vitro, nor was there any effect on time of allograft rejection.

Principal emphasis is currently on the development of portable extracorporeal irradiators adaptable to 
arteriovenous shunts, such as are typically installed in renal transplant patients. Candidate isotopes were screened relative to their ability to produce transit doses of over 10 rads to flowing blood without the necessity of massive shielding which would reduce portability and convenience. "Portable" irradiators currently described utilize ${ }^{90}$ Sr and ${ }^{90} \mathrm{Y}$ and require several pounds of shielding to absorb the bremsstrahlung. Iodine-125 and ${ }^{204} \mathrm{~T} 1$ have been shown to suitably irradiate blood and be shieldable, but they are either of too low specific activity or prohibitively expensive. Promethium-147 is available in suitable form, and devices using this isotope are being fabricated. We are attempting to obtain ${ }^{204} \mathrm{~T} 1$ with sufficient specific activity for similar use.

A sham model of the ${ }^{147} \mathrm{Pm}$ irradiator, weighing $200 \mathrm{~g}$ and $15 \mathrm{~cm}$ long, will soon be implanted in a beagle dog. A carotid-jugular shunt will be attempted; it is anticipated that the major problem will be the confirmation of continuous blood flow through the $2.5-\mathrm{mm}$ ID tubing of the shunt. Devices containing ${ }^{147} \mathrm{Pm}$ wil1 be tested as soon as reliable surgical preparations are developed. Standard commercially available arteriovenous shunt gear will be used to facilitate later transition to clinical trials. 


\section{MECHANISMS OF RADIATION EFFECTS}

The measurement of overt pathologic changes induced by ionizing radiation has produced data vital to the establishment of radiation protection standards. Such gross changes, however, as with most clinical measures, are the observed terminal effects of events occurring early in the growth, development, and differentiation of the cell. The studies included in this project are concerned with basic biologic and chemical indices that may aid in understanding the primary effects of the radiation insult and also serve in the diagnosis of such early effects. These studies were previously funded under the titles: "Cellular Regulatory Mechanisms," "Radiation-Induced Leukemogenesis," and "Characterization of Radiation-Induced Free Radical Reactions."

Several reports are concerned with the cell membrane of the eukaryotic microorganism Neurospora crassa, the regulation of enzymes located on the organelle, the nature of the organization of proteins in its structure, and the transport of nutrilities through a simple membrane system derived from it. Information is presented on the role of virus in ${ }^{90} \mathrm{Sr}$-induced leukemia. And there is a report on the kinetics of production of free radicals by ionizing radiation and their potential role in damaging cell membranes, employing both a simple synthetic membrane and red blood cells as targets for the radiationgenerated radicals.

\section{PUBLICATIONS}

DRUCKER, H. An Activation Step in the Induction of Exocellular Protease from Neurospora. Abstracts of the Annual Meeting of the American Society for Microbiology, p. 171 ( $A b-$ stract). 1972 .

DRUCKER, H. Regulation of ExocelzuLar Proteases in Neurospora crassa: Induction and Repression of Enzyme Synthesis. J. Bacteriol, vol. 110, p. 1041. 197\%

DRUCKER, H. Sensitive Radiochemical Assay for Proteolytic Activities. Anal. Biochem., vol. 46, p. 598. 1972.
DRUCKER, H. Tryptophan Repression of Exocelluzar Proteases in Neurospora. Abstracts of the Fourth International Fermentation Symposium, Kyoto, Japan, p. 222 (Abstract). 1972 .

DRUCKER, H. and L. L. CAMPBELL. EZectrophoretic and Immunological Differences Between the Cytochrome c 3 of Desulfovibrio desulfuricans and that of Desulfovibrio gigas. In Cytochromes: Current Research II,$M \overline{S S \text { Information }}$ Corp., New York. 1972.

DRUCKER, H., E. B. TROUSIL, G. H. BARLOW, and E. MARGOLIASH. Amino Acid 
Composition, Heme Content, and Molecular Weights of Cytochrome c 3 of Desulfovibrio desulfuricans and Desulfovibrio vulgaris. In Cytochromes: Current Research II, MSS Information Corp., New York. 1972.

FRAZIER, M. E., R. N. USHIJIMA, and J. R. PRATT. Characterization of a c-Type Virus Isolated from Leukemic Swine. Abstracts of the Annual Meeting of the American Society for Microbiology, p. 211 (Abstract). 1972 .

FRAZIER, M. E., R. N. USHIJIMA, J.R. PRATT, and T. K. ANDREWS. Celzular Immunity in Swine Chronically Exposed to $90 \mathrm{Sr}$. Radiat. Res.,

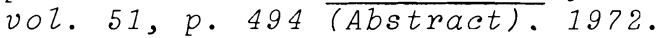

FRAZIER, M. E., R. N. USHIJIMA, J. R. PRATT, T. K. ANDREWS, and B. ROSARIO. Immunological and Virological Aspects of Radiogenic Leukemia in Miniature Swine. In Radionuclide Carcinogenesis, 12 th Annual Hanford Biology
Symposium ( $A E C$ Symposium Series), Battelie, Pacific Northwest Laboratories, Richland, Washington. 1973.

KALKWARF, D. R., D. L. FRASCO, and W. H. BRATTAIN. Ion-Diffusion Potentials and Electric Rectification Across EIM-Activated Lipid Membranes. Proc. Natl. Acad. Sci., vol. 69, p. 3765. 1972 .

WILEY, W. R. Spheroplast and Vesicle Formation from yeast and Fungi. In Methods in Enzymology, Biomembranes, Academic Press, New York (in press). 1973.

WILEY, W. R., R. B. SANDERS, and L. S. WINN. Induction and Properties of a Membrane-Bound Leucine-pNitroanilide Amidase in Neurospora crassa. Abstracts of the Annual Meeting of the American Society for Microbiology, p. 141 (Abstract). 1972 . 


\title{
INDUCTION OF EXOCELLULAR PROTEASES
}

\author{
Investigator: \\ H. Drucker \\ Technical Assistance: \\ Louise Neil
}

\begin{abstract}
Exocellular protease induction from Neurospora crassa appears to involve three types of processes: 1) activation of a cell-bound zymoprotease by an active proteolytic enzyme, 2) release of the resultant zymopeptide, facilitated by protein substrate, and 3) induction of protease at the level of the gene by the released zymopeptide. Kinetic evidence is presented to support this model. Amino acids can be grouped as to their effects on protease induction as follows: no effect-acidic and alcoholic amino acids, glycine, cysteine, catabolite repressors - chain aliphatic amino acids; specific repressors aromatic amino acids; and mixed repressors - basic amino acids. The aromatic amino acid tryptophan appears to repress through an intermediate in its catabolism, n-formyl kynurenine.
\end{abstract}

Previous work had shown that induction of protease from cells of $\underline{N}$. crassa, grown on sucrose and transferred to a salts medium, required a protein substrate, an active protease of defined specificity (the Bacillus protease thermolysin appeared to be the enzyme of choice) and protein synthesis. Information presented last year suggested a tenable model of induction, which can be stated briefly as follows: The first step in the induction of protease from $\mathrm{N}$. crassa involves the autocatalytic cleavage by limited proteolysis of an inactive protease zymogen located in the cell's periphytic space. In the experiments, where cells grown on a sugar were transferred to a medium containing protein as sole carbon source (log-phase cell experiments), this process is accelerated by the addition of added proteolytic enzyme. Two products (an active proteolytic enzyme and a zymopeptide) are generated by the postulated autocatalytic cleavage. The "inactive" product of cleavage (the zymopeptide) in the presence of a protein substrate enters the cell and serves as a "message" to the cell's genetic equipment. The peptide carries the information that a metabolizable protein, incapable of entering the ce11, 1 ies in the medium. In response to the message, the proteolytic enzyme (or enzymes) are synthesized and secreted into the milieu.

Using a limited number of time points, it was observed that the initial rate of protease induction from $10 \mathrm{~g}$-phase cells of $\underline{N}$. crassa was dependent upon the concentration of added thermolysin. In order to more accurately characterize the kinetics of protease induction and to determine a "threshold" concentration for added enzyme effect (that is, the lowest possible concentration resulting in induction of exocellular protease), 
log-phase cells were incubated in protein substrate; and thermolysin was added in concentrations of from 1 to $10 \mathrm{\mu g} / 100 \mathrm{~m} 1$ cells. Protease assays on culture filtrates were performed at 5-min intervals. This experiment demonstrated that the kinetics of protease induction can be described by three processes, two of which show a linear dependence on the concentration of added thermolysin. These three processes are: (a) a thermolysin-dependent release of enzyme from the cells. (b) A lag period of from 90 to 150 min during which no exocellular protease is synthesized. The duration of this lag period is dependent upon thermolysin concentration. The lag period is followed by protease synthesis at an initial rate which is again dependent upon the concentration of added protease.

(c) Protease biosynthesis enters into "log phase." The rate of synthesis at this point is not dependent upon added proteolytic activity.

No "threshold" effect was observed over the range of enzyme concentrations used in this experiment. Concentrations as 1 ow as $2.8 \times 10^{-10} \mathrm{M}$ thermolysin are capable of causing protease induction. Saturation with respect to added enzyme occurred at $7 \mu \mathrm{g} / 100 \mathrm{ml}$ or $2 \times 10^{-9} \mathrm{M}$.

All of the above observations are in agreement with the suggested model. There would appear to be an initial activation and release of zymoprotease from the cells. The initial rate and appearance of protease induction would seem to be dependent upon the concentration of released protease and thus of zymopeptide (an observation which would appear to confirm an earlier determination on accumulation of zymopeptide in induced cells). When new protease is made, the system becomes saturated; that is, the rate of activation of newly formed protease is no longer the rate-limiting step in protease induction, but rather further accumulation of protease is controlled by net rate of protein synthesis. The extremely low concentrations of thermolysin necessary to start the induction process are in keeping with its postulated enzymatic role (similar to the amounts normally used in autoactivation processes such as the conversion of trypsinogen to trypsin by the enzyme enterokinase). See Figure 1 .

The effects of individual amino acids on protease induction were examined at a range of concentrations from 0.098 to $0.98 \mu \mathrm{M} / \mathrm{ml}$. The dicarboxylic acids (glutamic and aspartic) and their amines were without effect on the induction process, as was also the case for serine, threonine, proline, glycine, and cysteine. The chain hydrocarbon amino acids (with the exception of isoleucine) and methionine have a marked effect on protease induction. They do not affect the thermolysin-dependent parameters of time of onset of protease induction or initial rate of protease synthesis. Rather, they decrease the log-phase rate of exocellular protease synthesis by a maximum of $41 \%$ at a concentration of 0.98 $\mu \mathrm{M} / \mathrm{m} 1$. Higher concentrations of these compounds do not lower this rate any further. These amino acids 


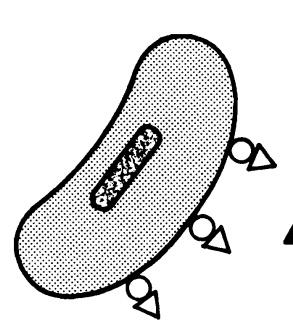

A. CELL PRIOR TO ACTIVATION BY ADDED PROTEASE. INACT I VE PRO TEASE (ZYMOGEN) BOUND TO MEMBRANE

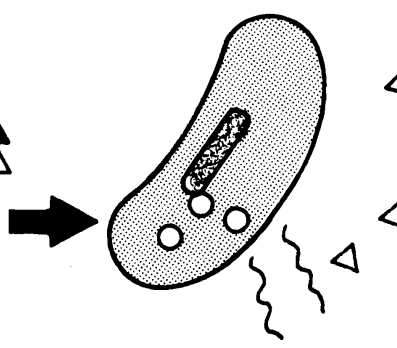

$\Delta$

B. ADDED PROTEASE CLEAVES ZYMOGEN, RELEASING ACTIVE ENZYME .
C. IN PRESENCE OF PROTEIN SUBSTRATE, ZYMOPEPTIDE ENTERS

CELL; AND

INDUCTION OF

PROTEASE OCCURS

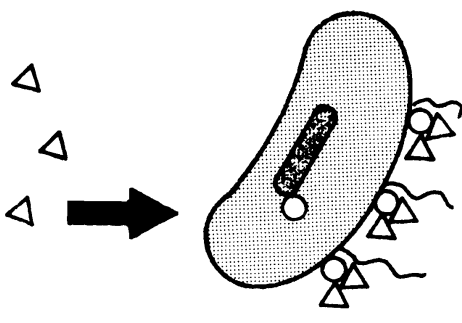

D. PROCESS CONTINUES

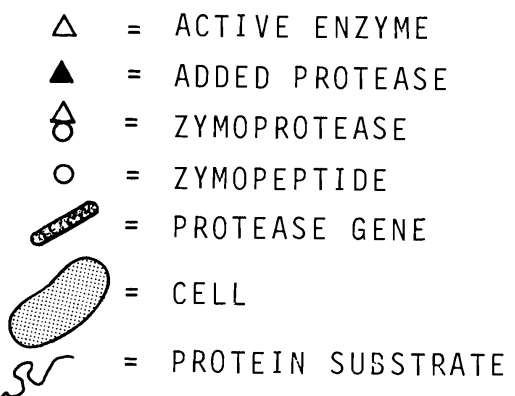

= PROTEIN SUSSTRATE

FIGURE 1. A Hypothesis for the Induction of Exocellular Protease from $\underline{N}$. crassa

may be considered as catabolite repressors of protease biosynthesis.

The basic amino acids, histidine, arginine, and lysine, differ from the hydrocarbon amino acids in that they appear to affect, in a concentration-dependent manner, the time of onset of protease induction, the initial rate of induction, and the logphase rate of protease biosynthesis. These data may imply that the basic amino acids are capable of both a specific repression of protease biosynthesis and catabolite repression (Table 1).

The aromatic amino acids appear to have the most interesting effects on protease biosynthesis. The time of initiation of induction is retarded in an amount proportional to the concentration of the added amino acid. Protease biosynthesis, once it occurs, proceeds at a rate similar to that of a control containing no added amino acids. Tryptophan appears to be the most efficient of this group with respect to repression. These amino acids would appear to behave as true specific repressors of protease biosynthesis and do not seem to effect catabolite repression.

The mechanism of tryptophan repression of protease biosynthesis was examined. In $\underline{N}$. crassa intracellular 
TABLE 1. Effects of Amino Acids on Protease Induction

A. No Effect

Glutamic acid and glutamine

Aspartic acid and asparagine

Serine

Threonine

Glycine

Cysteine

B. Catabolite repressors (affect the rate of protease biosynthesis)

Leucine

Valine

Methionine

C. Specific repressors (prevent synthesis of protease when present)

Tryptophan

Tyrosine

Phenylalanine

D. "Mixed" repressors (appear to behave as a combination of specific and catabolite repressors)

Histidine

Arginine

Lysine

tryptophan is converted to formy 1 kynurenine. This compound and kynurenine are capable of inducing kynureninase activities in the cell, and these enzymes convert formyl kynurenine to formyl anthranilic acid which is secreted by the cell into the medium. Bearing this in mind, these key products of tryptophan catabolism were examined for their effects on protease induction. The final products of tryptophan catabolism (an- thranilate and formyl anthranilate) had little or no effect on protease induction. The kynureninase-inducing compounds (kynurenine, hydroxykynurenine and formyl kynurenine) were, however, identical to tryptophan in their mode of repression of protease biosynthesis and in the concentrationdependence of this repression.

These observations suggest that tryptophan may repress protease biosynthesis through the intermediate in 
its catabolism, kynurenine. Further experiments appeared to substantiate this view. Various concentrations of tryptophan were added to log-phase cells in the presence of thermolysin and protein substrate. Exocellular protease and accumulation of the endproduct of tryptophan catabolism, anthranilate, were determined. In all cases where protease induction occurred during the time course of the experiment, complete removal of tryptophan (as indicated by the plateauing of anthranilate accumulated in the medium) was followed within 30 min by induction of protease. An identical picture in terms of anthranilate production and protease biosynthesis was observed when kynurenine or formyl kynurenine was used in place of tryptophan.

In another series of experiments, kynureninase induction under conditions identical to those described above was measured. Thirty minutes after the concentration of these enzymes reached plateau values, protease induction occurred.

These experiments suggest that kynurenine and its derivatives are specific repressors of protease induction. They do not prevent the initial release of protease from the cells (which is not dependent upon protein synthesis) but block net synthesis of proteolytic activity. Once these compounds are removed from the cell by the action of kynureninase, protease induction occurs at a control rate. All these observations imply that kynurenine may specifically block the inducing action of the thermolysin-generated peptide.
If this implication is true, then addition of tryptophan or kynurenine to cells at any time during the course of protease induction should cause a cessation of protease biosynthesis. This has been observed. Within 30 min after the addition of tryptophan or kynurenine to cells producing protease at 1 og rates, synthesis of the enzyme completely stops. Again, this cessation implies that these compounds are specific inhibitors of protease synthesis (Figure 2).

One further postulate with respect to tryptophan and kynurenine repression can be made. A mutant incapable of transporting these compounds should not be repressed by them. The N. crassa Mutant 1117 , which does not transport aromatic amino acids and which poorly transports neutral amino acids, was grown on sucrose and transferred to a medium containing protein as sole carbon source. Thermolysin was then added. The time course of protease synthesis was identical to that of wild type $\mathrm{N}$. crassa up to the period of $10 \mathrm{~g}$-phase enzyme synthesis; but, within the first hour of log-phase synthesis, levels of proteolytic enzyme reached a constant value; protease synthesis had ceased. It appeared that this transport-deficient mutant was incapable of taking up the amino acids and peptides released by the action of the induced protease on the protein substrate and thus, running out of carbon source, stopped its synthesis of enzyme. A low level of sucrose $(0.2 \%)$, found to stimulate protease synthesis in wild type $\underline{N}$. 


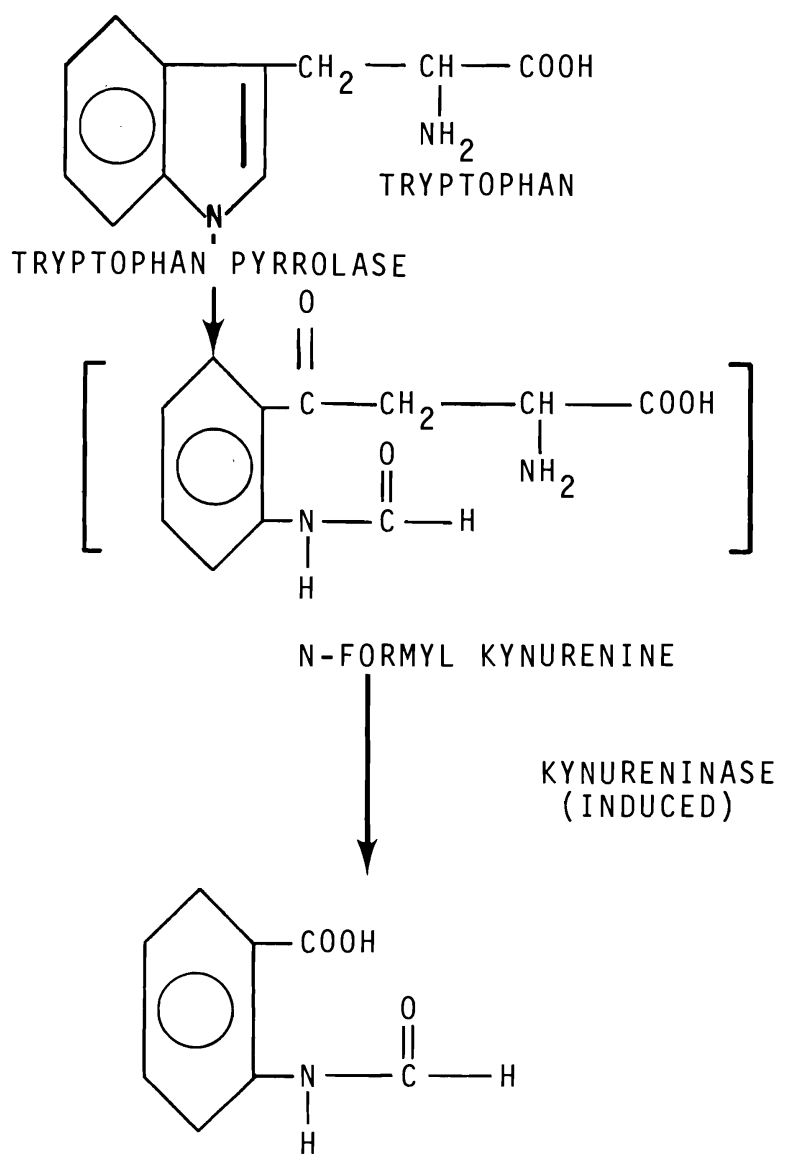
SPECIFIC REPRESSOR OF PROTEASE
BIOSYNTHESIS

N-FORMYL KYNURENINE IS CONVERTED

TO N-FORMYL ANTHRANILATE. REPRESSION

OF PROTEASE BIOSYNTHESIS IS RELAXED

AND PROTEASE IS INDUCED

N-FORMYL ANTHRANILIC ACID

FIGURE 2. The Pathway for Tryptophan Repression of Protease Biosynthesis

crassa, was added to the mutant cells in the medium containing protein plus thermolysin; and synthesis of protease equivalent to that of wild type cells was observed. As predicted, concentrations of tryptophan and kynurenine five times higher than those that stop protease synthesis in wild-type cells had no effect on the induction of protease from the mutant. Further, unlike the wildtype, sequential addition of sucrose resulted in an almost continual synthesis of the protease over a $12-\mathrm{hr}$ period. These cells apparently do not reach an intracellular concentration of amino acids sufficient to either specifically repress or catabolite-repress protease biosynthesis.

Our work on the regulation of an exocellular enzyme, as demonstrated in the case of $\underline{N}$. crassa Mutant 1117 , can lead to definitions of cell type and medium conditions for optimal protease production. It may contain within it a general model for the regulation of synthesis of mammalian 
exoce1lular proteins, both enzymes and hormones, which may allow

(1) eventual prediction of early pathological effects and (2) specific forms of treatment.

\section{CONTROL OF ENZYME INDUCTION AT THE MEMBRANE LEVEL}

Investigators:

W. R. Wiley and H. Drucker

Technical Assistance:

Laura S. Winn and Louise Neil

To study the initial event of protease induction, postulated to occur at the membrane, experiments were initiated involving spheroplasts and membrane vesicles. Membrane vesicles. and spheroplasts possess a protease zymogen which can be activated by thermolysin, as is the case with intact cells. Although proteolytic enzyme is released from purified spheroplasts, no detectable protease induction occurs. This is also the case for the slime mold mutant (ce11 wa11-deficient) of $\underline{N}$. crassa. Whether this reflects an absolute requirement for ce11 wall or a need for other metabolites in addition to protein is not known at this time.

However, we have observed that mycelia treated to form spheroplasts and which appear to have lost most but not all of their mycelial structure, will induce protease in a manner identical to wild-type cells. This observation and the observation that activation of membrane-bound zymoprotease occurs in a fashion similar to that observed in wildtype cells suggest that some amount of cell wall material may be essential for the protein synthesisdependent accumulation of protease to occur. Perhaps in the absence of certain cell wall components the zymopeptide message is not released into the cells.

It has become increasingly clear that the cytoplasmic membrane contains a variety of recognition sites which are capable of transmitting chemical and physical information about the external milieu into the interior of the cell, resulting, when possible, in a response to such changes. The models for protease induction and for induction of membranebound amino peptidase (described in previous report) are examples of this type of phenomenon; work with protoplasts and membrane vesicles may give new information about the structure and function of such systems. 


\author{
STUDIES ON NUTRILITE TRANSPORT \\ Investigator: \\ W. R. Wiley \\ Technical Assistance: \\ Laura S. Winn
}

\begin{abstract}
This report describes attempts to examine nutrilite accumulation in membrane vesicles prepared from plasma membranes of Neurospora crassa. The data suggest that the energy required for active transport in eukaryotic cells such as Neurospora is derived from mitochondria. These findings are not consistent with the findings observed for prokaryotic cells, where the energy source is a constituent of the plasma membrane.
\end{abstract}

Recent studies on the transport of nutrilites by closed membrane vesicles prepared from prokaryotic cells suggest that translocation and, consequently, accumulation in prokaryotes is coupled to specific dehydrogenases present in the membrane. Preliminary evidence suggests that the oxidation and reduction of the dehydrogenases occur via the cytochrome system. It is postulated that the coupling of energy derived from electron transport processes of this type to conformational changes in membrane transport proteins is the mechanism for nutrilite translocation.

Prokaryotic cells, unlike eukaryotic cells, do not possess mitochondria. The major constituents for oxidative phosphorylation are localized on the cytoplasmic membrane in prokaryotes. Because of this difference one would intuitively conclude that the mechanisms for translocation described for prokaryotes might not be applicable to eukaryotes (Figure 1). While this conclusion is certainly valid from a teleological point of view, the possibility of a specialized cytochrome system associated with the cell membrane in eukaryotic cells cannot be excluded. To test this possibility, we utilized the techniques developed in this laboratory for the preparation of cytoplasmic membrane vesicles from Neurospora. We examined the transport of nutrilite in these vesicles and the effects of electron-donating substrates and synthetic electron donors on this transport. We hoped to be able to characterize this system in the same fashion as the prokaryotic system and thus to delineate the differences and similarities between prokaryotic and eukaryotic nutrilite transport.

The two nutrilites used in these studies were 3-0-methyl glucose, an analog for glucose transport, and Larginine, an amino acid which was previously shown to be accumulated at very high ratios (intracellular concentration/extracellular concentration) in whole cells. Further, the protein carriers for both of these 


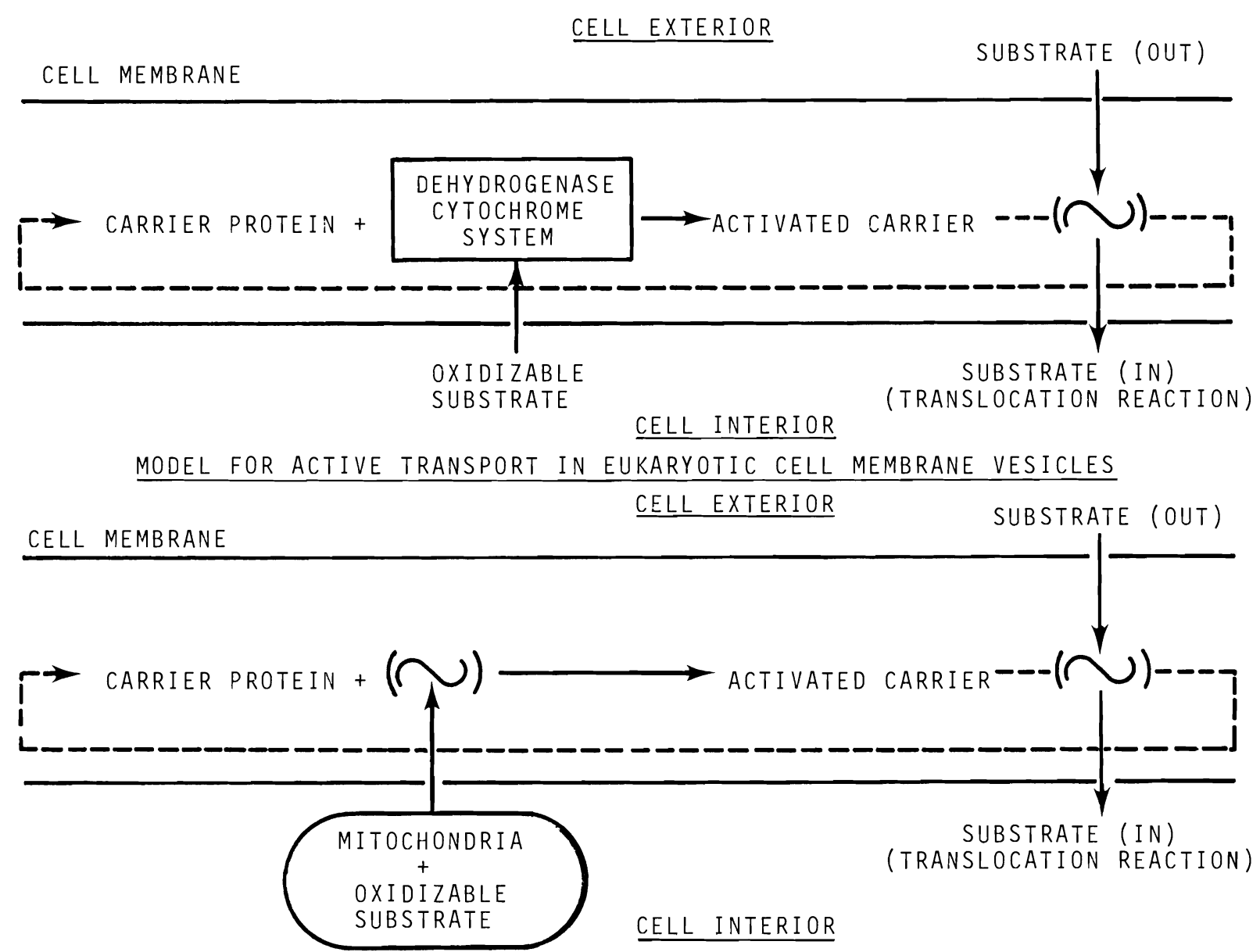

FIGURE 1. Mode1 for Active Transport in Prokaryotic $\overline{\mathrm{Ce} 11}$ Membrane Vesicles

systems were shown previously to be resistant to release from the membrane by osmotic shock.

Values for the accumulation of arginine in membrane vesicles are not reproducible from lot to lot of vesicles unless mitochondria are removed from the preparation. Mitochrondrial concentration, as measured by the level of the respiratory enzyme succinic dehydrogenase must be not more than $5 \%$ of that found in whole ce11s in order to achieve consistent results. Greater amounts of mitochondria result in a range for the ratio intracellular arginine/exoce11ular arginine of 3 to 5 at two concentrations of the amino acids $\left(2 \times 10^{-4} \mathrm{M}\right.$ and $\left.1 \times 10^{-5} \mathrm{M}\right)$. The final concentration ratio achieved after clarification from mitochondria is rather sma11, and attempts to increase the ratio by addition of a large number of substrates and artificial electron donors failed. The small, but significant, steady-state concentration gradient developed in the membrane vesicles was achieved in 4 to $5 \mathrm{~min}$ after the addition of radioactive arginine to the vesicle preparation. 
The steady-state plateau at 5 min was followed by a release of radioactivity from the vesicles at a rate which was approximately three times the rate of accumulation. The loss of arginine was interpreted to indicate that a continuous energy supply to maintain the accumulated pool was needed and that some unidentified energy donor may be the limiting factor. The limitation in pool size (concentration gradient) may also reflect this limitation.

Cells derepressed for glucose transport (possessing a transport system with a high affinity for glucose) did not accumulate 3-0-methy 1 glucose to any extent. The reasons for this are not clear. Glucose accumulation by membrane vesicles prepared from glucose transportrepressed cells was not attempted due to the low affinity for the substrate previously observed in whole cells.

Three lines of evidence suggest that there are similarities between the vesicle systems of the prokaryote E. coli and the eukaryote N. crassa:

a. Data on arginine accumulation in vesicles of $\underline{N}$. crassa suggest that the carrier sites for nutrilite transport and the translocation system involved in metabolite uptake are present as they are in E. coli vesicles.

b. Potassium cyanide, an inhibitor of oxidative enzymes, appears to inhibit accumulation of both arginine and glucose in membrane vesicle from N. crassa. This implies that an electron transport system may be involved in nutrilite accumulation in Neurospora as it is in E. coli.

c. Membrane vesicles from Neurospora have been shown to be closed sacs by scanning electron microscopy and by transmission electron microscopy of negatively stained preparations (Figure 2). This observation is also the case for vesicles isolated from E. coli.

Parallelism between the two systems is, however, far from complete. As we have stated, a number of electron donors for respiratory enzymes capable of facilitating transport in $\underline{E}$. coli have no effect on nutrilite transport in vesicles of $\underline{N}$. crassa.

If nutrilite translocation in eukaryotic organisms is not coupled to mitochrondria but rather is an intrinsic function of respiratory enzymes in the cell membrane, then the membrane vesicles of $\underline{N}$. crassa and other eukaryotes may be a most useful tool for delineating general metabolite transport. The data

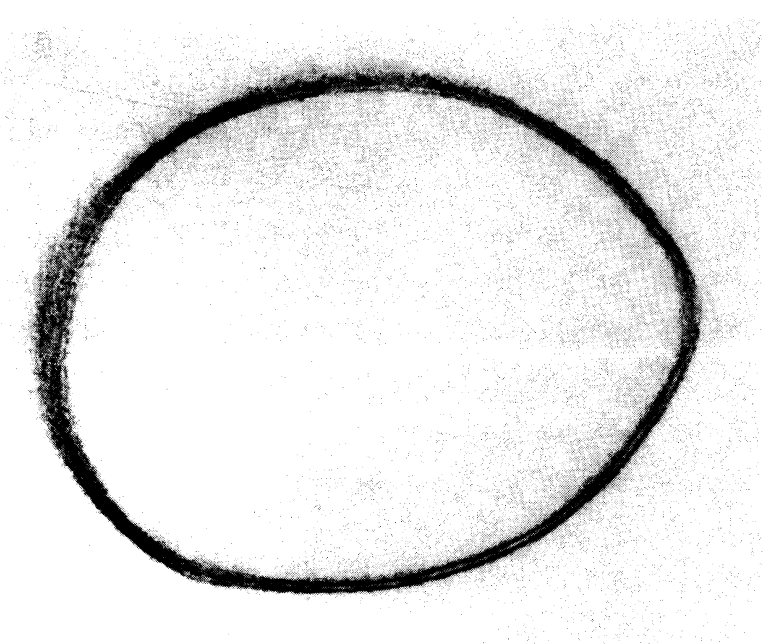

FIGURE 2. Electron Micrograph of a Vesicle Derived from the Membrane of Neurospora crassa 
available on this subject are equivocal and further research will be necessary to determine if, indeed, transport mechanisms of prokaryotes and eukaryotes can be treated as structurally and thus functionally identical.

\title{
STUDIES ON TRYPTOPHAN METABOLISM
}

\author{
Investigators: \\ $J$. R. Turner \\ Technical Assistance: \\ Lucilze M. Butcher
}

In previous studies we have demonstrated that regulation of intracellular activities can be affected by altered transport properties of the cell. A continuation of these studies has employed wild-type N. crassa Strain 74A, Mutant mtr 21 (altered in regulation of tryptophan transport), and Mutant mtr 21, su (a double mutant containing a supressor, su $^{\mathrm{mtr}}$, which allows tryptophan transport). When these organisms were supplemented with tryptophan in 1 og phase, only the wild-type and $\mathrm{mtr} 21$, su were capable of forming a large pool of the amino acid. On the other hand, when indole was used as a source of tryptophan, all three organisms formed a tryptophan pool of equal size. The indole-derived pool was approximately $1 / 8$ the size of the pool found in wild-type supplemented with tryptophan. There appears, however, to be a functional difference between the indole-derived pools of tryptophan in wild-type as compared with the mutants. Although wild-type will induce kynureninase when grown on indole, neither of the two mutant strains would induce this activity on indole. On tryptophan, the suppressed mutant would produce kynureninase activity, whereas the mtr 21 organism would not.

It has been suggested that there are two physiological pools of tryptophan in Neurospora. One pool, the metabolic pool, in addition to supplying tryptophan for protein synthesis, is thought to serve as a source of end product for the regulation of the tryptophan biosynthetic enzymes. The other pool (expandable pool) is considered as the source of inducer for the kynureninases. Evidence has been presented which appears to show that indole is converted to tryptophan which then enters the metabolic pool immediately, whereas tryptophan first enters the expandable pool after transport and then is transferred to the metabolic pool.

The data presented here appear to support this concept. In the mutant 
organisms, tryptophan, derived from indole, does not enter the expandable pool and thus cannot induce kynureninase, whereas tryptophan, which when transported enters the expandable pool directly, does induce kynuren- inase in the mtr 21, su mutant. Our results suggest that transport does affect the pooling of nutrilites and that this transport can cause alterations in the regulation of intracellular enzymes.

\title{
CHANGES IN THE SPECIFICITY OF THERMOLYSIN AS A FUNCTION
}

\section{OF CALCIUM CONCENTRATION}

\author{
Investigators: \\ H. Drucker and $M$. Unger* \\ Technical Assistance: \\ Louise Neiz
}

It has been demonstrated that a number of properties of the bacillus protease thermolysin are dependent upon Ca concentration. In particular, the kinetics of hydrolysis for the synthetic substrate 3-2 (furylacryloyl) glycyl leucinimide by this enzyme were dependent upon the concentration of $\mathrm{Ca}$, with values of both $\mathrm{K}_{\mathrm{m}}$ and $\mathrm{V}_{\max }$ changing by an order of magnitude as $\mathrm{Ca}$ concentration varied in the range $10^{-3}$ to $10^{-4} \mathrm{M}$. We had postulated on this basis that the specificity of thermolysin on a macromolecular substrate might be "tailored" to some extent by the proper adjustment of $\mathrm{Ca}$ levels during digestion.

To test this, carboxymethylated B-chain insulin was digested with thermolysin at various Ca concentrations. Samples were taken from the

*NORCUS fezzow digest mix as a function of time, and peptides resulting from enzymic digestion were separated by chromatography and electrophoresis on ce1lulose thin-layer plates. At $\mathrm{Ca}$ concentrations above $10^{-4} \mathrm{M}$, digestion proceeded rapidly; and at 8 min the limit of digestion (given the specificity of the enzyme) was reached, resulting in 12 to 13 peptides. At Ca concentrations from $10^{-4} \mathrm{M}$ to $10^{-5} \mathrm{M}$, however, digestion at $8 \mathrm{~min}$ resulted in only six peptides. After a period of 18 to $24 \mathrm{~min}$, total digestion of the protein substrate appeared to occur. These observations imply that the specificity of the enzyme on a protein substrate is not grossly altered by variation in $\mathrm{Ca}$ ion concentration but that the kinetics of hydrolysis for the substrate change substantially. This implication may be of use in protein sequence studies 
involving thermolysin. A given protein could be digested with thermolysin at $10^{-4} \mathrm{M} \mathrm{Ca}$ for a predetermined time, and the peptides isolated and characterized. Digestion of indi- vidual peptides could then be performed at $10^{-3} \mathrm{M} \mathrm{Ca}$, resulting in complete expression of thermolysin specificity.

\section{STUDIES ON THE ROLE OF VIRUS}

IN RADIONUCLIDE-INDUCED MALIGNANCIES

Investigators:

M. E. Frazier, R. N. Ushijima,

T. K. Andrews, and J. R. Pratt

In the past decade, a number of neoplastic processes have been associated with the appearance of virus particles. It now appears, in some cases, that the observed viruses are the etiological agents for the observed condition. Tumors and malignancies are among the more serious consequences of radiation exposure. This study deals with an analysis of one type of radiation-induced malignancy, myelogenous leukemia, in terms of what may be a primary agent in its development--a virus particle.

A survey of 46 miniature swine fed ${ }^{90} \mathrm{Sr}$ over an extended interval has revealed that of 34 animals with either myeloproliferative or 1ymphoproliferative disorders, 21 showed virus-1ike particles in their tissues or in plasma pellet preparations. The finding that 15 of 19 animals with myelogenous or lymphocytic leukemia had virus-1ike particles present may be of even greater signifi- cance. In contrast, no virus-1ike particles have been observed in preparations from control animals (Table 1).

A type-C virus has been isolated from 10 animals with myeloproliferative or 1ymphoproliferative disorders, and five of these virus preparations have now been purified and characterized as to several biophysical and biochemical parameters. As reported previously, these porcine virus isolates have properties similar to those of known oncogenic viruses. Porcine embryonic kidney (PEK) cells infected with the porcine type-C virus become transformed in vitro suggesting that this agent has an oncogenic potential. The cells transformed by the porcine viral isolates undergo a change in morphology from a fibroblastic type of cell to a cell culture in which epithelioid elements predominate. In addition, the transformed cells show a loss of normal 
TABLE 1. Electron Microscope Screening for Virus-Like

Particles in the Tissues and Plasma Pellets of Normal

and Leukemic Swine

\begin{tabular}{|c|c|c|}
\hline Pathologic Diagnosis & $\begin{array}{c}\text { Number } \\
\text { of Anima1s } \\
\text { Observed } \\
\end{array}$ & $\begin{array}{c}\text { Number of Animals } \\
\text { Having Virus-Like } \\
\text { Particles } \\
\end{array}$ \\
\hline Myelogenous leukemia & 15 & 11 \\
\hline $\begin{array}{l}\text { Lymphoproliferative } \\
\text { disorders }\end{array}$ & 4 & 4 \\
\hline Myeloid metaplasia & 15 & 6 \\
\hline Control (nonleukemic) & 12 & 0 \\
\hline
\end{tabular}

contact inhibition. The cells grow as foci of multilayered cells with random orientation rather than in the we11 ordered monolayer observed in cultures of normal PEK cells. Further, the transformed cells show both aneuploidy and polyploidy.

The host specificity of the porcine type-C virus is being examined, and preliminary evidence derived from studies of electron micrographs and $3_{\mathrm{H}-1 \text { abelled uridine incorporation }}$ indicates that cells from cats and monkeys will support the replication of the porcine isolate. The virus failed to replicate in hamster, mouse, or rabbit cell cultures.

In addition to the type-C virus particles observed in the majority of leukemic swine, we also have demonstrated the presence of mycoplasma and an amoeba (morphologically similar to Pneumocystic carinii) in some of the leukemic swine. 'These organisms have also been observed in cases of human leukemia, suggesting some degree of similarity between the two systems.

On the basis of the above, it would appear that radiation-induced porcine leukemia may be a good system for the study of radiation-induced malignancy. A potential etiological agent has been identified; parallels can be made to other mammalian leukemias; and the ability of the agent to transform normal porcine cells may allow a greater degree of flexibility than studies involving detection of pathology in animals. A number of methods for detecting early signs of biological radiation damage can be visualized as arising from this work.

In connection with these studies, Hanford miniature swine have been injected with ${ }^{253}$ Es, a radionuclide which appears to cause leukemia in rats. The blood of these animals is being analyzed for malignant pathology and will be screened for the presence of virus-1ike particles. 


\title{
STUDIES ON THE ROLE OF RADIATION-DERIVED FREE RADICALS
}

\section{IN BIOLOGICAL DAMAGE}

\section{Investigators:}

D. R. Kalkwarf and W. D. Felix

Technical Assistance:

C. Veverka, Jr.

\begin{abstract}
Low concentrations of free radicals produced by gamma irradiation of D-galactose crystals were found to destroy synthetic lipid bilayers and to hemolyze porcine red blood cells. In another study, the abilities of radicals to abstract $H$ atoms from a common substrate, glycine, were found to increase with decreasing electron density on the reactive site of the attacking radical.
\end{abstract}

Free-radical attack on biochemical membranes was evaluated as a process for amplifying the biologic effects of small radiation doses. In order to identify specific effects of the radicals, two well-characterized membrane systems were studied: synthetic bilayers composed of sphingomyelin and D- $\alpha$-tocopherol, and porcine erythrocytes suspended in isotonic saline solution. Particular radiation-induced radicals were introduced into both systems by dissolving irradiated crystals containing these species in the aqueous solutions surrounding the membranes. Prior to dissolution, the chemical structure of the radicals and their concentrations in the crystals were evaluated by electron spin resonance measurements.

The synthetic bilayers were found to be rapidly destroyed by exposure to small amounts of some radicals while being unaffected by others. Replicate membranes were prepared by painting films containing sphingo- myelin and $D$ - $\alpha$-tocopherol across a hole in polyethylene separating two compartments of distilled water. Each film thinned spontaneously to form a planar membrane, $1.5 \mathrm{~mm}^{2}$ in area and $70 \AA$ in thickness. Changes in its conductance and resting potential were monitored by making it an electrical circuit element. Rapid dissolution of irradiated D-galactose crystals in the we11-stirred aqueous phase destroyed the membrane within 1 min, while no such effect was observed when nonirradiated crystals of this substance were used. Addition of $2.4 \times 10^{17}$ radicals to the $40-\mathrm{m} 1$ aqueous phase repeatedly caused membrane destruction, and only a small fraction of these radicals could have reached the membrane surface before recombination. Phospholipid membranes thus appear to be critical sites for free-radical damage both in terms of sensitivity and in terms of damage amplification caused by destruction of control barriers. Stable radiolysis products of D-galactose 
did not cause destruction of the synthetic membranes, and only a small increase in their electrical conductance was noted when irradiated crystals were first dissolved in water to allow for radical recombination and then added on one side of the membrane. ESR measurements indicated that the radicals had the structure $\mathrm{R}-\dot{\mathrm{C}}(\mathrm{OH})-\mathrm{R}^{\prime}$ while chemical reactions with oxidation-reduction indicators showed that they could act as strong reducing agents. In contrast, irradiated crystals of glycine, shown to contain the oxidizing radicals $\mathrm{H}_{3}{ }^{\oplus} \mathrm{N}$ -
$\dot{\mathrm{C}} \mathrm{H}-\mathrm{COO}^{\ominus}$ and $\dot{\mathrm{C}} \mathrm{H}_{2} \mathrm{COO}^{\ominus}$, had no effect on these synthetic membranes.

A similar contrast in effects was observed when irradiated crystals of D-galactose and of glycine were rapidly dissolved in suspensions of porcine erythrocytes. In each case, the cells were washed free of the compounds and their stable radiolysis products within 2 min after exposure; and cell hemolysis and $\mathrm{K}^{+}$-efflux were measured as functions of time (Figure 1). Both of these processes occurred rapidly after irradiated Dgalactose crystals were dissolved

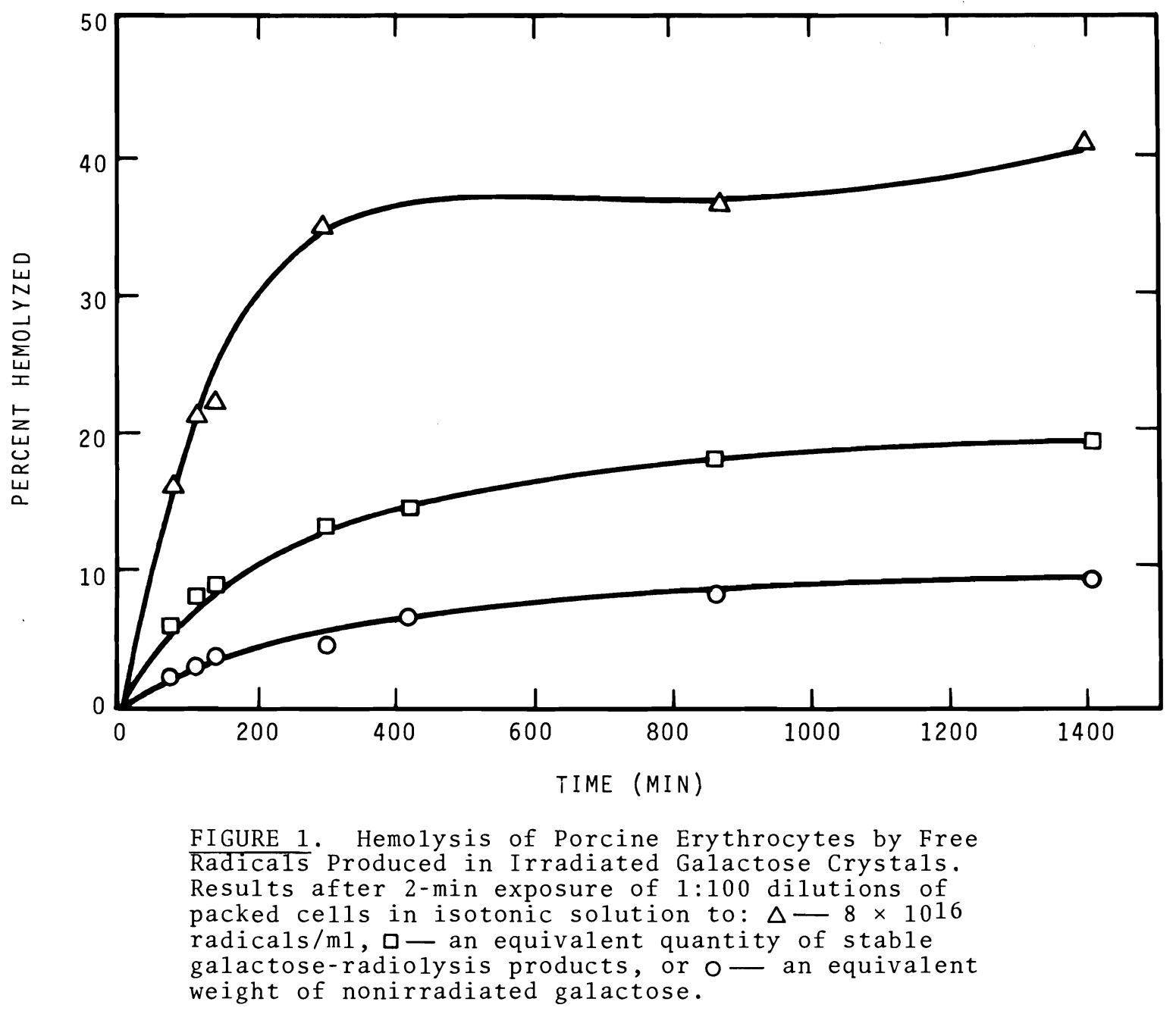


directly in the cell suspensions. Five hr after exposure to $3.2 \times 10^{17}$ radicals, 4-m1 samples of erythrocyte suspensions were $35 \%$ hemolyzed compared with $5 \%$ and $12 \%$ hemolysis in control samples which had been exposed to nonirradiated crystals or solutions of irradiated crystals, respectively. No significant hemolysis nor $\mathrm{K}^{+}$-efflux was observed when porcine erythrocytes were exposed to irradiated glycine crystals containing equal concentrations of radiationinduced radicals. Again, small concentrations of radicals capable of acting as chemical reducing agents significantly changed the transport properties of a biochemical membrane.

Capabilities for determining the kinetics of free-radical reactions with biochemical substrates were significantly improved with construction of a system for automatic retrieval of digital data from a single transient signal. Since these reactions last for only $10^{-6}$ to $10^{-3} \mathrm{sec}$, a high-speed recording system is required. A previously developed procedure, involving semi-automated collection of data from photographs of oscilloscope traces, was replaced by a new system which is compatible with both the flash photolytic equipment and the pulse radiolytic equipment planned for future use. This system consists of a transient digital recorder which is interfaced through a complex logic device to a magnetic tape drive unit. Transient signals which are held in the memory device are transferred as digital signals to the magnetic tape for computer processing. With the associated computer software, a considerable reduction in data retrieval and processing time has been achieved.

The relationship between the electronic structures of free radicals and their reactivities was examined in order to predict the most damaging radicals from among the great variety formed in irradiated tissue. In order to quantitatively evaluate this effect, reaction rates of a series of related radicals, $\mathrm{OH}^{*}, \mathrm{O}^{-}$, and $\mathrm{O}_{3}^{-}$ with a common substrate, glycine, were measured. Electron densities of these radicals around the oxygen atoms decrease in the order $\mathrm{O}_{3}^{-}>\mathrm{O}^{-}>$ $\mathrm{OH}^{\bullet}$. Radicals were produced by $f l a s h$ photolysis of aqueous solutions containing glycine; and the reactions, spanning a time range of $5 \mathrm{msec}$ were followed by means of the recently developed detection and data-handing system. Reaction of the ozonide radical-ion, $0_{3}^{\bar{j}}$, with glycine was undetectable while the ratio of reac-

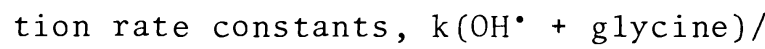
$\mathrm{k}\left(\mathrm{O}^{\mathbf{*}}+\mathrm{g}\right.$ lycine $)$, was found to be 10 when measured at the same $\mathrm{pH}$. In other words, the speed of hydrogen abstraction from glycine increased with decreasing electron density on the reactive site of the attacking radical. This finding suggests that theoretical evaluation of these densities can be used to select particularly reactive species for experimental tests of their abilities to damage biochemical structures. 
W. J. Bair, Ph.D. - Manager

Marguerite S. Stack - Secretary

Patricia M. Bresina - Clerk, MT/ST

Marilyn J. Love - Stenographer(1)

F. P. Hungate, Ph.D. - Staff Scientist and Education Coordinator(2)

R. C. Thompson, Ph.D. - Staff Scientist Judith A. Harrison - Clerk

W. R. Wiley, Ph.D. - Staff Scientist and Coordinator of Battelle Institute Life Sciences Program

Dev Felton, B.A. - Secretary

R. F. Hultman - Facilities Management

Janet I. Carlisle - Receptionist(3)

Gertrude G. Haggard - Clerk

Virginia E. Quinley - Receptionist(1)

LaDelle K. Schoenwald - Receptionist(1)

Sherri A. Stephens - Receptionist (4)

Maxine B. Worley - Receptionist(3)

\section{LIBRARIAN}

Elizabeth H. Groff - Technical Services Department

\section{BUSINESS OFFICE}

R. L. Crook, M.B.A. - Finance and Administration

R. H. Hove, B.A. - Finance and Administration(3) Ruth E. Palmer - Clerk(5)

\section{BIOMETRICS}

J. M. Thomas, Ph.D. - Research Associate

R. J. Olson, M.S. - Research Scientist

R. L. Buschbom, M.A. - Senior Research Scientist, Mathematics and Physics

Research Department

C. R. Watson, M.S. - Research Scientist, Mathematics and Physics Research Department

\section{RADIONUCLIDE COUNTING ROOM}

A. C. Case, B.A. - Radiological Sciences Department
(1) Part-Time
(2) Dual Capacity
(3) Terminated
(4) Transferred
(5) Nee Gates 


\section{INHALATION TOXICOLOGY SECTION}

J. F. Park, D.V.M. - Manager

Sharon A. Clemetson - Secretary

Professional Staff

Technical Staff

J. E. Ba11ou, Ph.D.

R. H. Busch, Ph.D.

W. C. Cannon, Ph.D. (1)

D. K. Craig, Ph.D.

R. E. Filipy, Ph.D.

J. P. Herring

K. E. McDonald

R. F. Palmer, M.S.

G. J. Powers

C. L. Sanders, Ph.D.

V. H. Smith, Ph.D.

B. O. Stuart, Ph.D.

A. P. Wehner, Dr. Med. Dent.

D. H. Willard, M.S.

Juanita S. Barnett

E. F. Blanton

J. D. Burruss

D. L. Catt

V. Daniels, Jr. (2)

B. T. Didway (3)

Julia N. Fitzner, B.S.

D. R. Fowler (2)

J. C. Gaven, Assoc. Arts and Science

S. W. $\operatorname{Hal1}(2)$

G. M. Louis

Robin M. Madison

Doris M. Meier

E. M. Milliman

W. G. Morrow

H. O. Myers (2)

Northwest College and University Association for Science Fellows (NORCUS)

C. A. Astley, B.S. (5)

C. S. Crom (6)

R. A. Jones (7)

Mary Meyer (8)

D. A. Neitze1

N. Perez

L. R. Peters

K. B. Pitman (2)

E. J. Rossignol

W. Skinner

V. C. Smith $(4,2)$

M. D. Snyder

H. G. Steele

K. C. Upton

G. L. Webb

E. L. Wierman

L. M. Williams (2)

G. F. Frank, M.D. 4300 Talbot Road No. 303 Renton, Washington

W. A. Zimmerman

G. Saccomanno, M.D. St. Mary's Hospital Grand Junction, Colorado

(1) NSF Presidential Intern

(2) Terminated

(3) Sick Leave

(4) Youth Opportunity Program (YOP)

(5) Washington State University, Pullman, Washington

(6) Oregon College of Education, Monmouth, Oregon

(7) Southern Oregon College, Ashland, Oregon

(8) Maryville College, St. Louis, Missouri 


\section{MEDICAL SCIENCES SECTION}

W. J. Clarke, D.V.M., Ph.D. - Manager(1)

M. F. Gillis, M.S., D.V.M. - Manager

Alta M. Skolrud - Secretary (2)

Martha E. Stifter - Clerk

Sandra E. Lemmons - Typist (3)

Professional Staff

J. L. Beamer, B.S.

J. R. Decker, B.S.

J. D. Eklund, B.S. (4)

M. J. Free, Ph.D.

Patricia L. Hackett, Ph.D.

F. P. Hungate, Ph.D. (5)

E. L. Hunt, B.S.

M. T. Karagianes, D.V.M.

N. W. King, Ph.D.

Beatrice J. McClanahan, Ph.D.

D. D. Mahlum, Ph.D.

H. A. Ragan, D.V.M.

M. R. Sikov, Ph.D.

Linda G. Smith, M.S.

Glenda S. Vogt, B.A.

Technical Staff

R. D. Carmichael

R. L. Chandler, B.S. Eugenia T. Edmerson

Marilin L. Greenwell, B.A.

Joan 0 . Hess

Darlene H. Hunter

M. J. McWhorter (2)

Martha C. Perkins

Jean D. Stearns

Northwest College and University Association for Science Fellows (NORCUS)

J. T. Bricker (6)

E. C. Coleman, M.S. (7)

M. C. Dedrick, Ph.D. (8)

Louise Mora(9)

Jeanne M. Smith (10)

\section{Consultants}

R. Ansbacher, M.D. Brooke General Hospital Fort Sam Houston, Texas

D. K. Clawson, M.D. University of Washington Seattle, Washington

D. S. Coffey, Ph.D. The Johns Hopkins University School of Medicine Baltimore, Maryland

J. E. Davis, M.D.

New York Medical College

New York, New York

\footnotetext{
(1) Transferred to Battelle Columbus

(2) Terminated

(3) Transferred to another Department

(4) Science and Engineering Program

(5) Dual Capacity

(6) Malone College, Canton, Ohio

(7) Texas College, Tyler, Texas

(8) AMGN State College, Pine Bluffs, Arkansas

(9) Marymount College, Salina, Kansas

(10) Fort Wright College, Spokane, Washington
}

R. Jaffe, M.S. University of California Medical Center San Francisco, California

S. Katsh, Ph.D. University of Colorado Medical Center Denver, Colorado

M. Lodme11, D.D.S . Walla Walla Medical Center Walla Walla, Washington

D. K. Merkeley, M.D.

W. A. Ricker, M.D. Laboratory of Clinical Medicine Seattle, Washington 


\section{MEDICAL SCIENCES SECTION (continued)}

Consultants (continued)

C. A. Paulsen, M.D. U.S. Public Health Service Seattle, Washington

S. S. Schmidt, M.D. Private Practice Eureka, California
E. Steinberger, M.D. University of Texas Medical School

Houston, Texas

G. D. Stibbs, D.M.D. School of Dentistry University of Washington Seattle, Washington 


\section{MOLECULAR BIOLOGY AND BIOPHYSICS SECTION}

H. Drucker, Ph.D. - Manager

Barbara J. Ellis - Stenographer

Professional Staff

R. R. Adee, B.S.

R. D. Castro, A.B. (1)

M. E. Frazier, Ph.D.

M. P. Fujihara

J. G. Hadley, B.S.

J. C. Hampton, Ph.D.

Beverly Johnson

R. D. Phillips, Ph.D.

B. Rosario, B.S.

R. B. Sanders, Ph.D. (2)

R. P. Schneider, $P{ }^{\prime}$. D.

M. Sernetz, Ph.D. (3)

M. F. Sullivan, Ph.D.

E. G. Tombropoulos, Ph.D.

J. R. Turner, Ph.D.

Laura S. Winn

Consultants

T. D. Mahony, M.D. Medical Arts Building Richland, Washington

K. Van Holde, Ph.D. Department Biophysics Oregon State University Corvallis, Oregon

J. G. Sinkovics, M.D.

M. D. Anderson Hospital

Tumor Institute

The Texas Medical Center Houston, Texas

R. N. Ushijima, Ph.D.

University of Montana

Missoula, Montana

\section{Technical Staff}

T. K. Andrews, B.A.

J. L. Armantrout (4)

Lucille M. Butcher

Alma L. Crosby

Fama D. Culver (5)

Heidi L. Curtis, B.S. (4)

V. T. Faubert

Johnie Harper (6)

C. C. Hill

Terri L. Jones

Louise C. Neil

Cody L. Rowe (4)

Patricia S. Ruemmler

G. Sue Schneiderman, B.S. (7)

K. A. Strikwerda

Clotis White

Mary A. Wood

Northwest College and University Association for Science Fellows

(NORCUS)

Helen E. Gruber, B.S. (8)

P. H. Grundy $(9)$

Mary Miller (10)

M. W. Unger, B.S. (11)

(1) Educational Leave of Absence

(2) Battelle Institute Fellow

(3) Battelle Frankfurt

(4) Terminated

(5) Hourly Call In

(6) Part-Time

(7) Temporary Full Time

(8) Oregon State University, Corvallis, Oregon

(9) Southern California College, Costa Mesa, California

(10) Maryville College, St. Louis, Missouri

(11) University of Illinois, Urbana, I11inois 


\section{ANIMAL RESOURCES CENTER}

V. G. Horstman, B.S. - Manager

Dev Felton, B.A. - Secretary

Professional Staff

Technical Staff

M. G. Brown

R. F. Howard

V. D. Tyler

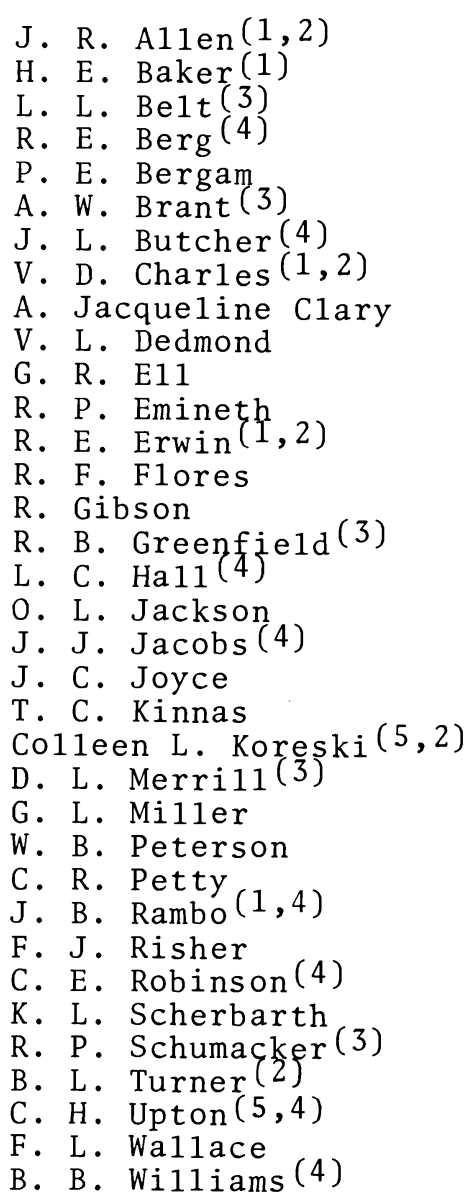

(1) Group A Trainee (TOPP)

(2) Transferred

(3) Temporary Ful1 Time

(4) Terminated

(5) YOP 


\section{GENERAL SERVICES \\ FACILITIES OPERATION DEPARTMENT}

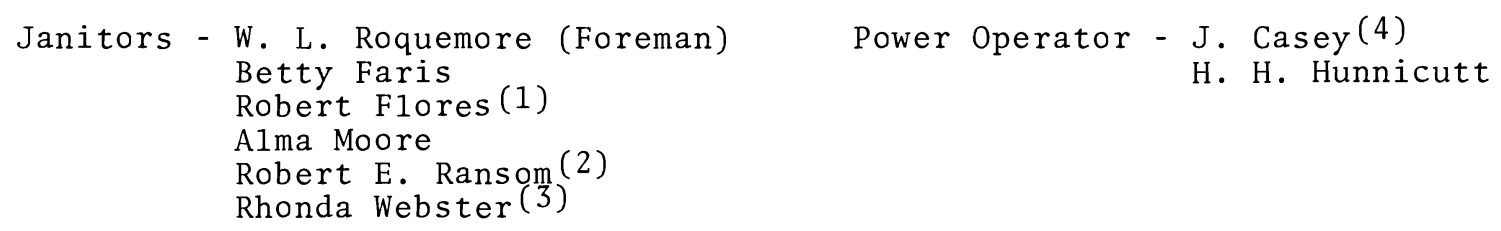

MAINTENANCE CRAFT SERVICES DEPARTMENT

L. F. Carpenter - Foreman

J. D. Hughes - Foreman

R. W. Walters - Foreman (2)

Carpenter - H. D. Longwe11

Electrical - J. M. Cole(1)

B. D. Corder (5)

R. G. Feaster (2)

D. W. Hendrickson

C. P. Julian(4)

D. J. Ne1son

F. O. Stout

\author{
Instruments - J. W. Cunningham \\ R. N. Martin \\ C. F. Mix \\ G. A. Sparks \\ S. A. Wilson \\ Material Coordinator - W. D. Elliott \\ Mil1wright - L. F. Conley \\ Pipefitters - R. A. Bennett \\ C. T. Ford \\ J. J. Gore \\ L. R. Ne1ms
}

Supervisor - E. D. McFal1

Specialist - M. W. Leale(1)

Radiation Monitors - G. V. Aasal

G. Botu

H. W. Dains

B. J. Merril1

R. C. Schrotke (1)

A. L. Stinnett (1)

\footnotetext{
(1) Transferred

(2) Terminated

(3) Deceased

(4) On Sick Leave

(5) Educational Leave
} 


\section{PUBLICATIONS AND PRESENTATIONS}

\section{OPEN LITERATURE PUBLICATIONS}

BALLOU, J. E. and J. O. HESS. BiZiary Plutonium Excretion in the Rat. Health Phys., vol. 22, p. 369. 1972.

BALLOU, J. E. and W. G. MORROW. The Disposition and Long-Term Effect of Intratracheally Instizled $253 \mathrm{Es}$ in Rats. Health Phys., vol. 23, p. 418. (Abstract). 1972 .

BALLOU, J. E., J. F. PARK, and W. G. MORROW. On the Metabolic Equivalence of Ingested, Injected and Inhaled 239 Pu Citrate. Health Phys., vol. 22, p. 857. 1972 .

BALLOU, J. E. and J. B. HURSH. The Measurement of Thoron in the Breath of Dogs Administered Inhaled or Injected ThO 2. Health Phys., vol. 22, p. 155. 1972 .

BAXTER, D. W. and M. F. SULLIVAN. Gastrointestinal Absorption and Retention of Plutonium Chelates. Health Phys., vol. 22, p. 785. 1972.

BUSTAD, L. K., M. GOLDMAN, L.S. ROSENBLATT, C. W. MAYS, N.W. HETHERINGTON, W. J. BAIR, R. O. MCCLELLAN, C.R. RICHMOND, and R. E. ROWLAND. Evaluation of LongTerm Effects of Exposure to Internally Deposited Radionuclides. Peaceful Uses of Atomic Energy 11, 125-140. IAEA, Vienna. 1972.

CLARKE, W. J., R. H. BUSCH, P. L. HACKETT, E. B. HOWARD, M. E. FRAZIER, B. J. MCCLANAHAN, H. A. RAGAN, and G. S. VOGT. Strontium-90 Effects in Swine: A summary to date, p. 242. In: M. Goldman and L. K. Bustad (Eds.), Biomedical Implications of Radiostrontium Exposure. (AEC Symposium Series 25) NTIS, Springfield, VA. 1972 .

CLARKE, W. J., P. L. HACKETT, M. E. FRAZIER, B. J. MCCLANAHAN, and H. A. RAGAN. Radiosensitivity of Swine to Chronic $90 \mathrm{Sr}$ Ingestion. Conference on Biological Effects of $90 \mathrm{Sr}$, University of California, Davis. (In Press). 1972.
CRAIG, D. K., R. L. BUSCHBOM, and J. P. HERRING. Relationships Between the Size Distribution of $239 \mathrm{PuO}_{2}$ Aerosols, Aerosol Concentration and Nebulizer Suspension Concentration. Health Phys., vol. 23, p. 428. (Abstract). 1972 .

CRAIG, D. K., J. M. THOMAS, J.R. DECKER, and J.F. PARK. Alveolar Deposition of $239 \mathrm{PuO}_{2}$ Aerosols in Beagle Dogs as a Function of Respiration and Aerosol Parameters. Health Phys., vol. 22, p. 845. 1972.

CRAIG, D. K., A. P. WEHNER, and W. G. MORROW. The Generation and Characterization of a Respirable Aerosol of Chrysotile Asbestos for Chronic Inhalation Studies. Amer. Ind. Hyg. Ass. J., vol. $33, p .283$. 1972 .

DECKER, J. R. and D. K. CRAIG. Alpha Aerosol Monitor: Rapid Determination of Low-Level Alpha Aerosol Concentrations. Health Phys., vol. 23, p. 429. (Abstract). 1972 .

DECKER, J. R. and M. G. GILLIS. A Completely Implantable Three Channel Temperature Biotelemetry System. Biomed. Sci. Instrum., vol. 9, p. 133. 1972 .

DILLEY, J. V. The Origin of Urinary Taurine Excretion During Chronic Radiation Injury. Radiat. Res., vol. 50, p. 191. 1972.

DRESLER, S. L. and J. R. TURNER. Neurospora Tryptophan Biosynthesis, Coordinate Induction by 3-AminoTriazole and Indole Acrylic Acid. Bacteriol. Proc., p. 156. (Abstract). 1971.

DRUCKER, H. An Activation Step in the Induction of Exocelzular Protease from Neurospora, p. 171. In: W. A. Wood, et al. (Eds.), 72 nd $\overline{A n n u a l}$ Meeting, American Society for Microbiology. (Abstract). 1972 .

DRUCKER, H. Regulation of Exocelzular Proteases in Neurospora crassa. I. Induction and Repression of Enzyme Synthesis. $\frac{J . \text { Bacteriol., }}{1972 .}$
vol. $110, p .1041$. 
DRUCKER, H. Sensitive Radiochemical Assay for Proteolytic Activities. Anal. Biochem., vol. 46, p. 598. 1972 .

DRUCKER, H. Tryptophan Repression of Exocelluzar Protease in Neurospora, p. G6-1. In: Fourth International Fermentation Symposium, Kyoto, Japan. (Abstract). 1972 .

DRUCKER, H. and L. L. CAMPBELL. Electrophoretic and Immunological Differences Between the Cytochrome c3 of Desulfovibrio desulfuricans and that of Desulfovibrio gigas. In: Cytochromes: Current Research $\overline{I I}$, MSS Information Corp., New York. 1972 .

DRUCKER, H., E. B. TROUSIL, G. H. BARLOW, and E. MARGOLIASH. Amino Acid Composition, Heme Content, and Molecular Weights of Cytochrome $c_{3}$ of Desulfovibrio desulfuricans and Desulfovibrio vulgaris. In: Cytochromes: Current Research II, MSS Information Corp., New York. 1972.

FRAZIER, M. E., R. N. USHIJIMA, and J. R. PRATT. Characterization of a c-Type Virus Isolated from Leukemic swine. Abstracts of the Annual Meeting of the American Society for Microbiology, p. 211. (Abstract). 1972 .

FRAZIER, M. E., R. N. USHIJIMA, J. R. PRATT, and T. K. ANDREWS. CelZuZar Immunity in Swine Chronically Exposed to 90Sr. Radiat. Res., vol. 51, p. 494. (Abstract). 1972 .

FRAZIER, M. E., R. N. USHIJIMA, J. R. PRATT, T. K. ANDREWS, and B. ROSARIO. Immunological and Virological Aspects of Radiogenic Leukemia in Miniature Swine. In: Radionuclide Carcinogenesis, 12 th Hanford Biology Symposium, May 11-13, 1972 .

FUJIHARA, M. P. and F. P. HUNGATE. Seasonal Distribution of Chrondrococcus columnaris Infection in River Fishes as Determined by Specific Agglutinins. J. Fish. Res. Bd. Canada, vol. $29, p .173 .1972$.

HAMPTON, J. C. Acute Radiation Effects in Kidney. Radiat. Res., vol. 52, p. 316. 1972.
HAMPTON, J. C. and B. ROSARIO. The Fine Structure of Intestine and Liver in Irradiated Mice During Fat Absorption. Radiat. Res., vol. 52, p. 152. 1972 .

HAMPTON, J. C. and B. ROSARIO. Permeability of Arterial Internal Elastic Laminae in Irradiated Mice. Exp. Mol. Pathol., vol. 17, p. 307. 1972.

HAMPTON, J. C. and B. ROSARIO. Radiation Effects on Chyzomicron Synthesis in Mice. Radiat. Res., vol. 51, p. 441. (Abstract). 1972.

HAMPTON, J. C., B. ROSARIO, and R. R. ADEE. Exogenous Perioxidase Localization in Irradiated Arteries, p. 8. In: C. J. Arceneaux (Ed.), 30 th Annual Meeting, Electron Microscopy Society of America. Claitor's Publishing Division, Baton Rouge. 1972 .

HUNGATE, F. P., J. E. BALLOU, D. D. MAHLUM, M. KASHIMA, V. H. SMITH, C. L. SANDERS, D. W. BAXTER, M. R. SIKOV, and $R$. C. THOMPSON. Preliminary Data on $253 \mathrm{Es}$ and $249 \mathrm{BK}$ Metabolism in Rats. Health Phys., vol. 22 , p. 653. 1972 .

HUNGATE, F. P. and D. W. BAXTER. $253 \mathrm{Es}$ and $249 \mathrm{BK}$ Uptake and Distribution in Rats. Radiat. Res., vol. 51, p. 542. (Abstract). 1972.

HUNT, E. L., R. D. PHILLIPS, R. D. CASTRO, and N. W. KING. General Activity of Rats Immediately Following Exposure to $2450 \mathrm{MHz}$ Microwaves. J. Microwave Power, vol. 7, p. 285. (Abstract). 1972 .

KALKWARF, D. R., D. L. FRASCO, and W. H. BRATTAIN. Ion-Diffusion Potentials and Electric Rectification Across EIM-Activated Lipid Membranes. Proc. Nat. Acad. Sci., vol. 69, p. 3765. 1972 .

KALKWARF, D. R., M. R. SIKOV, L. SMITH, and R. GORDON. Release of Progesterone from Polyethylene Devices in Vitro and in Experimental Animals. Contraception, vol. 6, p. 423. 1972.

KASHIMA, M., D. D. MAHLUM, and M. R. SIKOV. Metabolism and Effect of Monomeric and Polymeric Plutonium in the Immature Rat Liver. Health Phys. vol. $22, p .749 .1972$. 
MCDONALD, K. E., J. F. PARK, R. J. $O L S O N, R$. H. BUSCH, and C. L. SANDERS. Removal of Inhaled $239 \mathrm{PuO}_{2}$ from Beagle Dogs by Pulmonary Lavage. Health Phys., vol. 23, p. 425. (Abstract). 1972 .

MCKENNEY, J. R. Electrolyte Fluxes and Electrical Potentials in Isolated Rat Intestine, p. 81. In: S. C. Skornya and D. Waldron-Edward (Eds.), Intestinal Absorption of Metal Ions.

Pergamon Press, Oxford. 1972.

MAHLUM, D. D. Hepatic Tumor Development in Rats Exposed to $144 \mathrm{Ce}$ and Dimethylaminoazobenzene. In: Radionuclide Carcinogenesis, 12 th Hanford Biology Symposium, May 11-13, 1972 .

MAHLUM, D. D. and M. R. SIKOV. Metabolism and Toxicity of 253 Es Relative to Age. Radiat. Res., vol. 51, p. 502. (Abstract). 1972 .

MAHLUM, D. D. and M. R. SIKOV. Physico-Chemical and Biological Interactions in Rare Earth Metabolism, pp. 537-550. In: P. E. Field (Ed.), Proceedings of the 9 th Rare Earth Research Conference, vol. 2, (CONF711001) NTIS, Springfield, VA. 1972.

NELSON, I. C. A Simplified Method for Evaluating the Healy Plutonium Excretion Equations. Health Phys., vol. 22, p. 191. 1972.

PALMER, R. F., J. M. THOMAS, C. R. WATSON, and J. L. BEAMER. Radiation Doses to 90 Sr-Fed Swine, p. 114. In: M. Goldman and L. K. Bustad (Eds.), Biomedical Implications of Radiostrontium Exposure. (AEC Symposium Series 25) NTIS, Springfield, VA. 1972.

PARK, J.F., W. J. BAIR, and R. H. BUSCH. Progress in Beagle Dog Studies with Transuranium Elements at Battelle-Northwest. Health Phys., vol. 22, p. 803. 1972 .

RAGAN, H. A. Platelet Agglutination Induced by Ethylenediaminetetraacetic Acid in Blood Samples from a Miniature Pig. Amer. J. Vet. Res., vol. 33, p. 2601. 1972.

RAGAN, H. A., P. L. HACKETT, B. J. MCCLANAHAN, and W. J. CLARKE. Pathologic Effects of Chronic $90 \mathrm{Sr}$ Ingestion in Miniature Swine. National Conference on Research Animals in Medicine. (In Press). 1972.
ROEHM, J. N., D. B. MENZEL, and S. D. LEE. Vitamin E: The Biological and Environmental Antioxidant. J.Agr. and Food Chem., vol. $20, p . \overline{481}$. 1972 .

ROEHM, J. N., J. G. HADLEY, and D. B. MENZEL. The Influence of Vitamin $E$ on the Lung Fatty Acids of Rats Exposed to Ozone. Arch. Environ. Health, vol. 24, p. 237. 1972.

SANDERS, C. L. Carcinogenesis of Inhaled 238 Pu Derived from Crushed Microspheres. Radiat. Res., vol. 51, p. 492. (Abstract). 1972.

SANDERS, C. L. Deposition Patterns and the Toxicity of Transuranium Elements in Lung. Health Phys., vol. $22, p .607$. 1972 .

SANDERS, C. L. Production of $A b-$ dominal Mesotheliomas in Rats with $239_{\mathrm{PuO}_{2}}$ and Chrysotile Asbestos. Health Phys., vol. 23, p. 418. (Abstract). 1972 .

SANDERS, C. L. and T. A. JACKSON. Induction of Mesotheiromas and Sarcomas from "Hot Spots" of $23 \mathrm{PuO}_{2}$ Activity. Health Phys., vol. 22 , p. 755. $19 \overline{72}$.

SANDERS, C. L., T. A. JACKSON, and R. R. ADEE. Induction of MesotheZiomas and Sarcomas by IntraAbdominal Deposits of $239 \mathrm{PuO}_{2} \mathrm{Par}-$ ticles. In: W. J. Bair and R. C. Thompson (Eds.), The Biological Implications of the Transuranium Elements, Health Phys., vol. 22, p. 755. 1972 .

SCHNEIDER, R. P. and W. R. WILEY. Transcription and Degradation of Messenger Ribonucleic Acid for a Glucose Transport System in Neurospora, p. 138. In: mRNA: $\overline{\text { Current }}$ Research. I., MSS Information Corporation, New York, NY. 1972.

SIKOV, M. R. and D. D. MAHLUM. AgeDependence of 239 Pu Metabolism and Effect in the Rat, p. 261. In: B. J. Stover and W. S. S. Jee, (Eds.), Radiobiology of Plutonium. J. W. Press, University of Utah, Salt Lake City. 1972.

SIKOV, M. R. and D. D. MAHLUM. Distribution of $253 \mathrm{Es}$ in the Fetoplacental Unit of the Rat. Radiat. Res., vol. 51, p. 543. (Abstract). 1972. 
SIKOV, M. R. and D. D. MAHLUM. Plutonium in the Developing Animal. Health Phys., vol. 22, p.707. 1972.

SIKOV, M. R., D. D. MAHLUM, and W. J. CLARKE. Effect of Age on the Carcinogenicity of 131 I in the Rat. In: Radionuclide Carcinogenesis, 12 th Hanford Biology Symposium, May 11-13, 1972 .

SIKOV, M. R., D. D. MAHLUM, and E. B. HOWARD. Effect of Age on the Morphologic Response of the Rat Thyroid to Irradiation by Iodine-131. Radiat. Res., vol. 49, p. 233. 1972.

SIKOV, M. R., R. L. PIMMEL, F. R. REICH, and $J$. L. DEICHMAN. Visualization of Soft Tissue by UZtrasonic Holography. Radiology, vol. 102, p. 191. 1972.

SIKOV, M. R., F. R. REICH, and J. L. DEICHMAN. Biomedical Studies Using Ultrasonic Holography. In: Glen Wade (Ed.), Accoustical Holography, vol. 4, p. 147. 1972.

SMITH, V. H. Comparison of Efficiency of Removal of Plutonium, Cerium and Zine from Rats by $\mathrm{Ca}$ - and Zn-DTPA. Radiat. Res., vol. 51 , p. 540. (Abstract). 1972 .

SMITH, V. H. The Effect of Mass on Promethium Retention and Removal from the Rat. Health Phys., vol. 23, p. 31. 1972 .

SMITH, V. H. Metal-DTPA Chelates in Biological Systems - A Bibliography. BNWL-1657, Battelle, Pacific Northwest Laboratories, Richland, WA. 1972 .

SMITH, V. H. Some Aspects of Chelation Therapy for Internal Contamination with Actinide Elements. Health Phys., vol. 23, p. 425 . (Abstract). 1972 .

SMITH, V. H. Therapeutic Removal of Internaliy Deposited Transuranium Elements. Health Phys., vol. 22 , p. 765. $19 \overline{72 .}$

SMITH, V. H., Edited translation. TRNOVEC, T., and A. PLESKOVA. Mechanisms of Hepatic Uptake of Hepatotropic Radionuclides. BNWLtr-71. 1972 .
STUART, B. O., R. H. BUSCH, and R. F. PALMER. Studies of the Effects of Inhaled Radon Daughters, Uranium Ore Dust, and Diesel Engine Exhaust in Hamsters. Health Phys., vol. 23, p. 417. (Abstract). 1972.

STUART, B. O., D. H. WILLARD, and E. B. HOWARD. Studies of Inhaled Radon Daughters, Uranium Ore Dust, and Cigarette Smoke in Dogs and Hamsters. In: Inhaled Particles III, p. 543, Unwin Bros. Lt'd., Gresham Press, England. 1972.

SULLIVAN, M. F., J. L. BEAMER, T. D. MAHONEY, and B. W. WACHHOLZ. The Hanford Swine as a Model for Studies of Intracavitary Irradiation by Californium-252. Radiat. Res., vol. 51, p. 446. (Abstract). 1972.

SWINTH, K. L., J. F. PARK, and P. MOLDOFSKY. Counting Plutonium in the Tracheobronchial Lymph Nodes. Health Phys., vol. 22, p. 899. 1972.

THOMPSON, R. C., J. F. PARK, and W. J. BAIR. Some Speculative Extensions to Man of Animal Risk Data on Plutonium, p. 221. In: B. J. Stover and W. S. S. Jee (Eds.), Radiobiology of Plutonium. J. W. Press, University of Utah, Salt Lake City. 1972.

THOMPSON, R. C. and W. J. BAIR, eds. Hanford Symposium on the Biological Implications of the Transuranium Elements. Health Phys., vol. 22, (6). 1972 .

TOMBROPOULOS, E. G. Palmitate Incorporation into Lipids by Lung Subcezlular Fractions. Biochem. J. (In Press). 1972.

WACHHOLZ, B. W., M. KASHIMA, and M. F. SULLIVAN. On the Mechanism of Protein Leakage by the Irradiated Intestine. Radiat. Res., vol. 51, p. 442. (A bstract). 1972 .

WEHNER, A. P. and D. K. CRAIG. TOxicology of Inhaled $N i O$ and $C O O$ in Syrian Golden Hamsters. Amer. Ind. Hyg. Ass. J., vol. 33, p. 145. 1972.

WEHNER, A. P., D. K. CRAIG, and B. O. STUART. An Aerosol Exposure System for Chronic Inhalation Studies with Rodents. Amer. Ind. Hyg. Ass. J., vol. 33, p. 483. 1972. 
WILEY, W. R. Spheroplast and Vesicle Formation from Yeast and Fungi. In: Methods in Enzymology, Biomembranes, Academic Press, New York. (In Press). 1973.

WILEY, W. R., R. B. SANDERS, and L. S. WINN. Induction and Properties of a Membrane-Bound Leucine-p-Nitroanilide Amidase in Neurospora crassa. Abstracts of the Annual Meeting of the American Society for Microbiology, p. 141. (Abstract). 1972.

PRESENTATIONS AT SOCIETY MEETINGS AND SYMPOSIA

BAIR, W. J. Summary of AEC Research on Inhaled Radon, Mesa County Medical Society, Boulder, CO, March 7-8, 1972 .

BALLOU, J. E. and W. G. MORROW. The Disposition and Long-Term Effect of Intratracheally Instilled $253 \mathrm{Es}$ in Rats, Health Physics Society, Las Vegas, NV, June 12-16, 1972.

BROWN, M. G. and J. F. PARK. Facilities for Production and Maintenance of Beagle Dogs for Life-Span Studies with Radionuclides, 23 rd Annual Session, American Association for Laboratory Animal Science, St. Louis, Mo, October 15-20, 1972 .

CLARKE, W. J. New Porous Materials for Dental and Orthopedic Application, Annual California Dental Appreciation Meeting, San Francisco, CA, Apriz 1719, 1972; also given at American Academy of Gold Foil operators, University of Kentucky, Lexington, KY, February 9-14, 1972 .

CRAIG, D. K. Open End Discussion, Air Cleaning Conference (U.S.A.E.C.), oak Ridge, TN, August 28-31, 1972.

CRAIG, D. K., R. L. BUSCHBOM, and J. P. HERRING. Relationships Between the Size Distribution of $239 \mathrm{PuO}_{2}$ Aerosols, Aerosol Concentration and Nebulizer Suspension Concentration, Health Physics Society, Las Vegas, NV, June 12-16, 1972.
CULVER, G. G., F. P. HUNGATE, and W. F. RIEMATH. Fabrication of an Implantable Blood Irradiator, 19th American Vacuum Society Symposium, Chicago, IL, October 2-6, 1972 .

DECKER, J. R. An Instrument for Continuous Monitoring of Tidal Volume of the Beagle Dog, 7 th Annual Meeting of the Association for the Advancement of Medical Instrumentation, Las Vegas, NV, Apriz 23-26, 1972.

DECKER, J.R. and D. K. CRAIG. Alpha Aerosol Monitor; Rapid Determination of Low-Level Alpha Aerosol Concentrations, Health Physics Society, Las Vegas, NV, June 12-16, 1972.

DECKER, J. R. and M. F. GILLIS. A Completely Implantable Three Channel Temperature Biotelemetry System, 9th Annual Rocky Mountain Bioengineering Symposium and 19th International ISA Biomedical Sciences Institute Symposium, Omaha, NB, May 1-3, 1972.

DRUCKER, H. An Activation Step in the Induction of Exocellular Protease, Annual American Society for Microbiology, Philadelphia, PA, April 23-28, 1972.

DRUCKER, H. Induction of Protease by Zymogen Activation, Seminar at ohio State University, Columbus, $O H$, october 15-22, 1972 .

DRUCKER, H. Tryptophan Repression of Exocellular Protease in Neurospora, 7 th Annual International Fermentation Symposium, Kyoto, Japan, March 1925,1972 .

ERDMAN, H. B. Population Performance and Chronic Gamma Radiation, Joint Meeting of the southwestern Branch of the Entomological Society of America and Sociedad Mexicana de Entomologia, Mexico City, Mexico, February 13-16, 1972 .

FRAZIER, M. E. Detection of VirusLike Particles from Radiation-Induced. Leukemia in Swine, Ph.D. Thesis, University of Montana, Missoula, MT, : December 8, 1972 .

FRAZIER, M. E. Viruses and Cancer. American Cancer Society, Southern Oregon Unit, Medford, OR, March 27-30, 1972 . 
FRAZIER, M. E., R. N. USHIJIMA, and J. R. PRATT. Characterization of $C$ Type Virus Isolated from Leukemic Swine, American Society for Microbiology, Philadelphia, PA, April 23, 1972 .

FRAZIER, M. E., R. N. USHIJIMA, J. R. PRATT, and T. K. ANDREWS. CeZZuZar Immunity in Swine Chronically Exposed to $90 \mathrm{Sr}$, Radiation Research Society, Portzand, OR, May 14-18, 1972.

FRAZIER, M. E., R. N. USHIJIMA, J. R. PRATT, and T. K. ANDREWS. Immunological and Virological Aspects of Radiogenic Leukemia in Miniature Swine, Hanford Biology Symposium on Radionuclide Carcinogenesis, Richland, WA, May 11-13, 1972.

FREE, M. J. Venous-Arterial Interactions Involving 5-Hydroxytryptamine in the Pampiniform Plexus of the Rat and Effects of Gonadotrophins on Glucose and Acetate Metabolism by Normal and Cryptorchid Rat Testis in vitro, Seminar, Pacific Northwest Foundation, Seattle, WA, December 11, 1972 .

FREE, M. J. and W. R. GOMES. A Testosterone Concentration Mechanism in the Reproductive Organs of the Male Rat, Federation of American Societies for Experimental Biology, Atrantic City, NJ, April 15-20, 1972.

HAMPTON, J. C. and B. ROSARIO. Radiation Effects on Chylomicron Synthesis in Mice, Radiation Research Society, Portland, OR, May 14-18, 1972.

HAMPTON, J. C., B. ROSARIO, and R. R. ADEE. Exogenous Perioxidase Localization in Irradiated Arteries, 3oth Annual Meeting of Electron Microscopy Society of America, Los Angeles, CA, August 14-18, 1972.

HORSTMAN, V. G. Biology at Hanford, Eastern State Hospital, Medical Lake, WA, February 3, 1972.

HORSTMAN, V. G. Pigs, Man and Radioisotopes, St. Patricks School, Pasco, WA, March 28, 1972; also given at Hanford Environmental Health Foundation, Richland, WA, March 30 , 1972 .

HORSTMAN, V. G. Pigs, Man and Radionuclides, American Association for Laboratory Animal Sciences, Anaheim, CA, May 20-26, 1972 .
HORSTMAN, V. G. Using Miniature Swine in Biomedical Research, $23 r d$ Annual Session - American Association for Laboratory Animal Science, St. Louis, MO, October 16-20, 1972.

HUNGATE, F.P. and D. W. BAXTER. 253 Es and $249 B k$ Uptake and Distribution in Rats, Radiation Research Society, Portzand, OR, May 14-18, 1972 .

HUNGATE, F. P. and B. J. MCCLANAHAN. Preliminary Data on Chromosome Aberrations in Swine and Human Leukocytes with a Brief Review of Factors Affecting Their observed Frequency, Conference on Research in Animals in Medicine, Washington, D.C., January 28-30, 1972.

HUNT, E. L., R. D. PHILLIPS, R. D. CASTRO, and N. W. KING. General Activity of Rats Immediately Following Exposure to $2450 \mathrm{MHz}$ Microwaves, Microwave Power Symposium, Ottawa, Canada, May 23-26, 1972.

HUNT, E. L., R. D. PHILLIPS, and N. W. KING. Absolute Dosimetry for Whole Animal Experiments. Joint Army Georgia Institute of Technology Symposium and Workshop on Microwave Dosimetry. Atranta, GA, June 1-2, 1972 .

KARAGIANES, M. T. Porous Metals as a Hard Tissue Substitute. Part I., Clemson University, Clemson, $S C$, Apriz 2-6, 1972; also given at Polymeric Uses in Artificial organs Symposium, Pasadena, CA, November 17, 1972 .

KARAGIANES, M. T. Porous Metal for Orthopedic/Orthodontic Application, Society for Experimental Biology and Medicine, Joint Center for Graduate Study, Richland, WA, october 28 , 1972 .

KARAGIANES, M. T. Swine in Biomedicine, American Association for Laboratory Animal Science, Anaheim, CA, May 20, 1972.

MCDONALD, K. E., J. F. PARK, R. J. OLSON, R. H. BUSCH, and C. L. SANDERS. Removal of Inhaled $239 \mathrm{PuO}_{2}$ from Beagle Dogs by Pulmonary Lavage, Health Physics Society, Las Vegas, $N V$, June 12-16, 1972. 
MAHLUM, D. D. Hepatic Tumor Development in Rats Exposed to ${ }^{144} \mathrm{Ce}$ and Dimethy Zaminoazobenzene (DAB), Hanford Biology Symposium on Radionuclide Carcinogenesis, May 11-13, 1972 .

MAHLUM, D. D. Nutritional and Environmental Influences on Behavioral Development, Seminar, Washington State University, PulZman, WA, January 4, 1972.

MAHLUM, D. D. and M. R. SIKOV. Metabolism and Toxicity of $253 \mathrm{Es}$ Relative to Age, Radiation Research Society, Portland, OR, May 14-18, 1972.

OLSON, R. J., M. G. BROWN, and J. F. PARK. Management of a Beagle Colony for Life-Span Studies with Radionuclides as Aided by a Computer Storage and Retrieval System, $23 r d$ Annual Session, American Association for Laboratory Animal Science, St. Louis, MO, October 15-20, 1972 .

PHILLIPS, R. D., E. L. HUNT, and N. W. KING. Vital Functions of Rats After Exposure to $2450 \mathrm{MHz}$ Microwaves, 7 th Annual Symposium of the International Microwave Power Institute, Ottawa, Canada, May 23-26, 1972.

RAGAN, H. A. Clinical Hematology, Southeastern Washington Veterinary Medical Association, Richland, WA, April 18, 1972.

RAGAN, H. A., P. L. HACKETT, B. J. MCCLANAHAN, and W. J. CLARKE. PathoZogic Effects of Chronic $90 \mathrm{Sr}$ Ingestion in Miniature Swine, Conference on Research Animals in Medicine, Washington, D.C., January 28-30, 1972 .

RAGAN, H. A., P. L. HACKETT, B. J. MCCLANAHAN, M. E. FRAZIER, and W. J. CLARKE. Late Effects of Chronic $90 S r$ Ingestion in Miniature Swine, Second International Conference on Strontium Metabolism, Glasgow, Scotland, August 16-19, 1972.

SANDERS, C.L. Carcinogenesis of Inhaled $238 \mathrm{Pu}$ Derived from Crushed Microspheres, Radiation Research Society, Portland, OR, May 14-18, 1972 .
SANDERS, C. L. Co-Carcinogenesis of $239 \mathrm{PuO}_{2}$ with Chrysotile Asbestos or Benzpyrene in the Rat Abdominal Cavity, Hanford Biology Symposium on Radionuclide Carcinogenesis, Richland, WA, May 11-13, 1972.

SANDERS, C. L. Production of Abdominal Mesotheliomas in Rats with $239^{\mathrm{PuO}_{2}}$ and Chrysotile Asbestos, Health Physics Society, Las Vegas, NV, June 12-16, 1972 .

SIKOV, M. R. Age-Dependence of 239 Pu Metabolism and Effect in the Rat, University of Rochester, New York, $N Y$, November 16, 1972.

SIKOV, M. R. Plutonium in the Developing Animal, U.S. Atomic Energy Commission, Division of Biomedical and Environmental Research, Washington, D.C., November 9, 1972.

SIKOV, M. R. and B. P. HILDEBRAND. A Retrospective and Prospective View of Ultrasonic Holography in Biology and Medicine, Association for the Advancement of Medical Instrumentation Annual Meeting, Las Vegas, $N V$, Apriz 24-26, 1972 .

SIKOV, M. R. and D. D. MAHLUM. Distribution of 253 Es in the Fetoplacental Unit of the Rat, Radiation Research Society, Portiand, OR, May 14-18, 1972 .

SIKOV, M. R., D. D. MAHLUM, and W. J. CLARKE. Effect of Age on the Carcinogenicity of 131 I in the Rat, Hanford Biology Symposium on Radionuclide Carcinogenesis, Richland, WA, May 11-13, 1972 .

SMITH, V. H. Comparison of Efficiency of Removal of Plutonium, Cerium and $Z$ inc from Rats by $\mathrm{Ca}$ - and Zn-DTPA, Radiation Research Society, Portzand, OR, May 14-18, 1972.

SMITH, V. H. Some Aspects of Chelation Therapy for Internal Contamination with Actinide Elements, Health Physics Society, Las Vegas, NV, June 12-16, 1972 .

STUART, B. O. Mineral Dust Exposure and Cigarette Smoke: Studies of the Effects of Radon Daughters, Uranium ore Dust, and Cigarette Smoke in Beagle Dogs, 2nd Conference on Respiratory Disease in Industry, Skytop, PA, May 16-18, 1972 . 
STUART, B. O., R. H. BUSCH, and R. F. PALMER. Studies of the Effects of Inhaled Radon Daughters, Uranium Ore Dust, and Diesel Engine Exhaust in Hamsters During Lifetime Daily Exposures, Health Physics Society, Las Vegas, NV, June 12-16, 1972.

STUART, B. O., D. H. WILLARD, R. F. PALMER, and R. H. BUSCH. Studies on Carcinogenic and other Biologic Effects of Inhaled Uranium Mine Air Contaminants in Hamsters and Dogs, Hanford Biology Symposium on Radionuclide Carcinogenesis, Richland, WA, May 11-13, 1972 .

SULLIVAN, M. F., J. L. BEAMER, T. D. MAHONY, and B. W. WACHHOLZ. The Hanford Swine as a Model for Studies of Intracavitary Irradiation by Californium-252, Radiation Research Society, Portiand, OR, May 14-18, 1972 .

THOMPSON, R. C. Biology of Plutonium and Transplutonium Elements, Health Physics Society, Las Vegas, NV, June 12-16, 1972.

TURNER, J.R. Occurrence of Kynureninase in N. Crassa, Seminar, Washington state University, Pullman, WA, April 6-8, 1972; also given at Seminar, Department of Microbiology, Oregon State University, Corvalzis, OR, February 29 to March 1, 1972.

WACHHOLZ, B. W., M. KASHIMA, and M. F. SULLIVAN. On the Mechanism of Protein Leakage by the Irradiated Intestine, Radiation Research Society, Portzand, OR, May 14-18, 1972.

WEHNER, A. P. Biological Effects of Air Ions and Their Potential in Agriculture, Board of Directors Meeting, Herd's Corporation, Seattle, WA, December 1, 1972.
WEHNER, A. P. A New Technical Approach to Electro-Aerosol Therapy, 6th International Biometeorological Congress, Noordwijk, The Netherlands, September 3-9, 1972 .

WEHNER, A. P. Physiological Effects of Air Ions and Electro-Aerosols, Guest Lecture at Symposium on Aeroionotherapy, Budapest, Hungary, september 12-14, 1972.

WEHNER, A. P., R. H. BUSCH, and D. K. CRAIG. Investigation of Cocarcinogenicity of Asbestos, Cobalt Oxide (COO), Nickel Oxide (NiO), Diethylnitrosamine and Cigarette Smoke, Carcinogenesis collaborative Conference, San Antonio, TX, October 2-4, 1972 .

WILEY, W. R. CelzuZar and Regulatory Mechanisms, Seminar, Southern University, Baton Rouge, LA, Apriz 1-8, 1972 .

WILEY, W. R. Regulation of Sugar Transport in N. Crassa, Seminar, University of Leicester, Department of Biochemistry, Leicester, England, october 21, 1972; also given at Seminar, Oak Ridge National Laboratory, Biology Division, Oak Ridge, TN, June 25-28, 1972.

WILEY, W. R., R. B. SANDERS, and L. S. WINN. Induction and Properties of a Membrane-Bound Leucine-pnitroanilide amidase in Neurospora crassa, American Society for Microbiology, Philadelphia, PA, April 23-29, 1972; also given at Hoffman-La Roche, Nutley, NJ, Apriz 22, 1972. 


\section{DISTRIBUTION}

\section{No. of \\ Copies \\ OFFSITE}

1 AEC Chicago Patent Group

G. H. Lee

19 AEC Division of Biomedical and Environmental Research

N. F. Barr

W. W. Burr

C. W. Edington

R. J . Enge1mann

M. Goldman

J. D. Goldstein (4)

H. Hollister

J. S. Kirby-Smith

J. L. Liverman

K. E. Lockridge

C. Osterberg

J. Swinebroad

B. W. Wachholz

J. C. Whitnah

J. N. Wolfe

R. W. Wood

194 AEC Technical Information Center

\section{ONSITE - HANFORD}

1 AEC/RL Patent Attorney

R. M. Poteat

1 AEC/RL RDT Site Representative, PNP

F. Standerfer

2 AEC Richland Operations Office

W. E. Lotz

1 Atlantic Richfield Hanford Company

A. E. Barber

4 Battelle Memorial Institute

R. S. Paul

1 Douglas United Nuclear, Inc. DUN File

2 Hanford Environmental Health Foundation

P. A. Fuqua

G. H. Crook

1 U.S. Testing

W. V. Baumgartner
No. of Copies

482

Batte11e-Northwest

E. L. Alpen

W. J. Bair (412)

T. M. Beet1e

S. A. Bush

D. L. Condotta

J. P. Cor 1ey

D. K. Craig

R. L. Crook

G. M. Dalen

J. M. Davidson

G. J. Dau

P. J. Dionne

G. E. Driver

H. Drucker

C. E. Elderkin

S. J. Farmer

P. L. Farnsworth

J. W. Finnigan

R. F. Foster

J. C. Fox

J. J. Fuquay

M. F. Gillis

J. C. Hampton

W. A. Haney

A. J. Haverfield

K. R. Heid

V. G. Horstman

F. P. Hungate

J. J. Jech

D. R. Kalkwarf

L. J. Kirby

H. V. Larson

K. K. Leeser

C. W. Lindenmeier

R. P. Marsha 11

C. E. Newton, Jr.

J. M. Nielsen

R. E. Nightingale

D. E. Olesen

J. F. Park

H. M. Parker

D. W. Pearce

L. T. Pedersen

R. W. Perkins

W. D. Richmond

W. C. Roesch

L. C. Schwendiman

A. J. Scott

C. L. Simpson

M. F. Sullivan

K. L. Swinth

W. L. Templeton

R. C. Thompson

C. M. Unruh

B. E. Vaughan

R. G. Wheeler

W. R. Wiley 
No. of

Copies

Batte11e-Northwest (contd)

Biology Library (2)

Technical Information Files (5)

Technical Publications
No. of

Copies

4 Battelle - Seattle

G. W. Duncan

H. Ede1hertz

D. J. Prager

J. E. Rasmussen 